\title{
Repurposing Suburbia
}

\author{
Tenny Vasilyan
}

A thesis submitted to the Faculty of Graduate Studies and Research

In partial fulfillment of the requirements for the degree of

Professional Masters of Architecture

Azrieli School of Architecture

Carleton University

Ottawa, Ontario

Advisor: Benjamin Gianni

(C) Copyright 2011

Tenny Vasilyan 


$\begin{array}{ll}\begin{array}{l}\text { Library and Archives } \\ \text { Canada }\end{array} & \begin{array}{l}\text { Bibliothèque et } \\ \text { Archives Canada }\end{array} \\ \begin{array}{l}\text { Published Heritage } \\ \text { Branch }\end{array} & \begin{array}{l}\text { Direction du } \\ \text { Patrimoine de l'édition }\end{array} \\ \begin{array}{l}\text { 395 Wellington Street } \\ \text { Ottawa ON K1A ON4 } \\ \text { Canada }\end{array} & \begin{array}{l}395, \text { rue Wellington } \\ \text { Ottawa ON K1A ON4 } \\ \text { Canada }\end{array}\end{array}$

Your file Votre référence

ISBN: 978-0-494-81627-1

Our file Notre référence

ISBN: 978-0-494-81627-1

NOTICE:

The author has granted a nonexclusive license allowing Library and Archives Canada to reproduce, publish, archive, preserve, conserve, communicate to the public by telecommunication or on the Internet, loan, distribute and sell theses worldwide, for commercial or noncommercial purposes, in microform, paper, electronic and/or any other formats.

The author retains copyright ownership and moral rights in this thesis. Neither the thesis nor substantial extracts from it may be printed or otherwise reproduced without the author's permission.
AVIS:

L'auteur a accordé une licence non exclusive permettant à la Bibliothèque et Archives Canada de reproduire, publier, archiver, sauvegarder, conserver, transmettre au public par télécommunication ou par l'Internet, prêter, distribuer et vendre des thèses partout dans le monde, à des fins commerciales ou autres, sur support microforme, papier, électronique et/ou autres formats.

L'auteur conserve la propriété du droit d'auteur et des droits moraux qui protège cette thèse. Ni la thèse ni des extraits substantiels de celle-ci ne doivent être imprimés ou autrement reproduits sans son autorisation.
In compliance with the Canadian Privacy Act some supporting forms may have been removed from this thesis.

While these forms may be included in the document page count, their removal does not represent any loss of content from the thesis.
Conformément à la loi canadienne sur la protection de la vie privée, quelques formulaires secondaires ont été enlevés de cette thèse.

Bien que ces formulaires aient inclus dans la pagination, il n'y aura aucun contenu manquant.

\section{Canada}




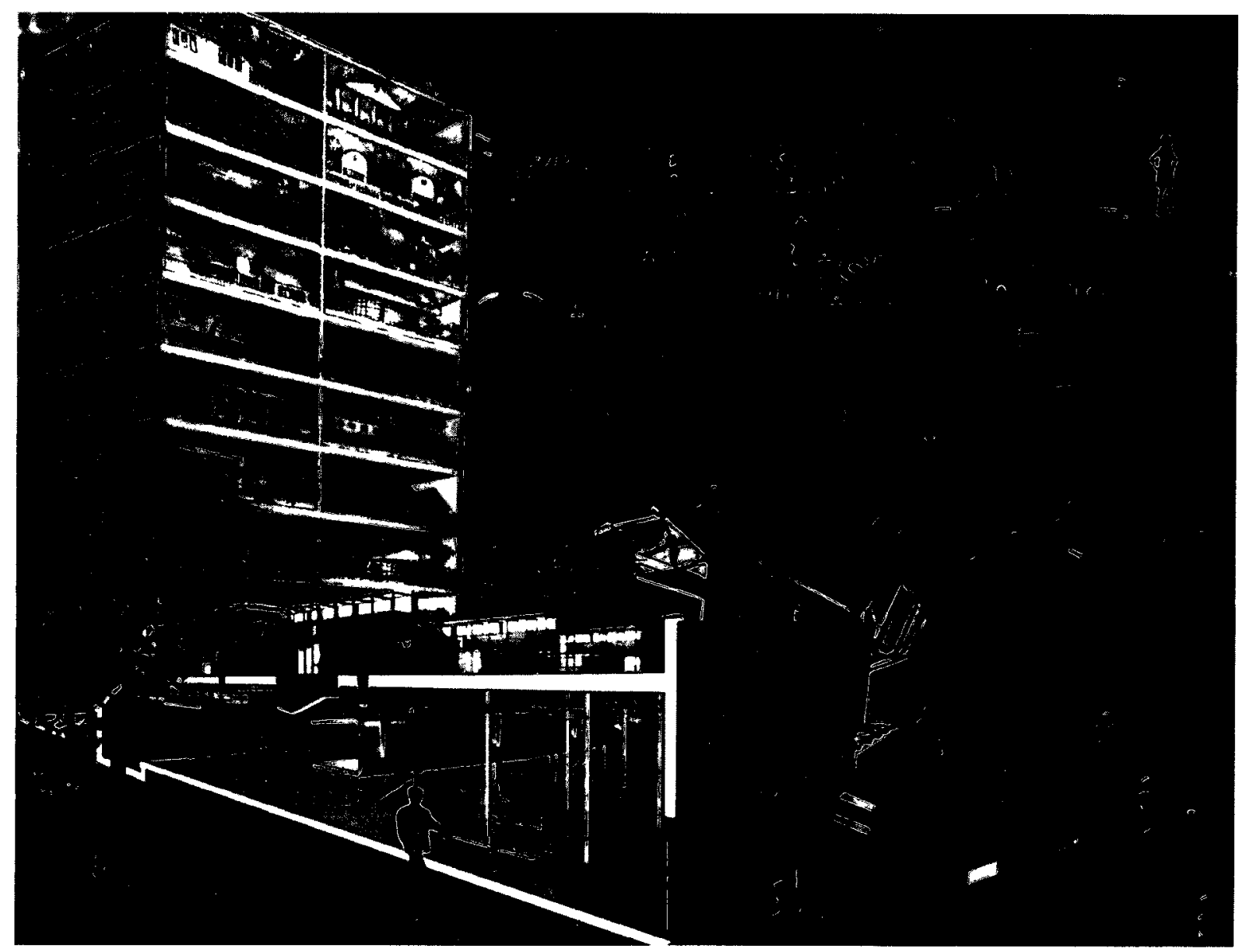




\section{Abstract}

Since the turn of the $20^{\text {th }}$ century, architects, planners, and designers have attempted to create a place in suburbia for the betterment of society. Low-density single-family homes, separated and segregated functions, and automobiles thus far characterize the morphology of North American suburbs; these combined with government policies continually lead to the sprawl of our nation. The thesis proposes a method of "fixing" or "repurposing" existing suburbs by transforming underdeveloped sites (greyfields) into mixed-use complexes that complete local neighbourhoods. To repurpose suburbia methods of implementing densification, intensification, mixing of both houses and uses, and incorporating public spaces on greyfield sites along transit corridors. The design portion focuses on a site in suburban Toronto; however, the intent is to identify strategies and techniques that to apply to a number of analogous sites all over suburbs in North America. 
Thank you Ben for your patience and guidance during the thesis process, your advice has been invaluable. And most importantly THANK YOU to my family and friends for the unconditional understanding, encouragement, love and support throughout the years. 


\section{Table of Contents}

1 INTRODUCTION 1

2 CRITIQUES OF SUBURBIA 3

CRITIQUES THROUGHOUT THE $20^{\text {TH }} \mathrm{C} \quad 4$

$\begin{array}{ll}\text { CURRENT CRITIQUES } & 7\end{array}$

$\begin{array}{lll}3 & \text { PRECEDENTS } & 16\end{array}$

$\begin{array}{ll}\text { TYPES OF LAND DEVELOPMENT } & 17\end{array}$

GREENFIELD 17

GREYFIELD $\quad 17$

$\begin{array}{ll}\text { ATTEMPTS TO DO SUBURBIA DIFFERENTLY } & 19\end{array}$

GARDEN CITY AND NEW TOWN 19

NEIGHBOURHOOD MODEL $\quad 26$

HIGH DENSITY AND HIGH-RISE $\quad 29$

SHOPPING MALLS AND THIRD PLACE 32

NEW POST-MODERN VISIONS 38

4 TORONTO MORPHOLOGY 44

5 PROJECT OF ARCHITECTURE $\quad 49$

6 CONCLUSION $\quad 80$

$\begin{array}{ll}\text { FUTURE WORK } & 82\end{array}$

$\begin{array}{ll}\text { APPENDIX } & 83\end{array}$

$\begin{array}{ll}\text { BIBLIOGRAPHY } & 101\end{array}$ 


\section{List of Illustrations}

FIG 01. Greyfield site in Toronto. Source: Google Maps

FIG $02 . \quad$ The Three Magnets. Source: Ebenezer Howard, Garden City of To-Morrow

FIG 03. View of Vallingby. Source:

FIG 04. Reston, Virginia PA Satellite Image. Source: Google Maps

FIG 05. Columbia, Maryland Satellite Image. Source: Google Maps

FIG 06. Clarence Perry's Neighbourhood Unit. Source:

<http://hugeasscity.com/2008/12/18/the-neighborhood-school/>

FIG 07. Radburn, New Jersey. Source: http:/www.radburn.org/geninfo/radburn-intro.html

FIG 08. Don Mills Satellite Image. Source: Google Maps

FIG 09. Contemporary City for 3 Million Inhabitants. Source: David Rudlin, Sustainable Urban Neighbourhood

FIG 10. Reston Town Centre. Source: http://smenulty.com/pointsofinterest.html http://www.stratfordcondominiums.net/Stratford.html

FIG 11. Reston Town Centre Site Plan. Source: http://www.restontowncenter.com/

FIG 12. Views of Shops at Don Mills. Source: $w$ ww.shopsatdonmills.ca

FIG 13. The Edge of Metropolitan Toronto. Source: Graeme Stewart, Concrete Toronto

FIG 14. Potentiality of Prototypical Nodes. Source: Graphic by Author

FIG 15. Overall Site Plan. Source: Graphic by Author

FIG 16. The Before and After Look of LRT Line. Source: TransitCity

FIG 17. Existing Site Images. Source: Graphic by Author

FIG 18. Ring Diagram. Source: Graphic by Author

FIG 19. Proposed Plan. Source: Graphic by Author

FIG 20. Function Breakdown. Source: Graphic by Author

FIG 21. Before and After-1. Source: Graphic by Author

FIG 22. Before and After - 2. Source: Graphic by Author

FIG 23. View of Central Public Space and Connections. Source: Graphic by Author

FIG 24. View of Mound Housing and Terraces. Source: Graphic by Author

FIG 25. SmartCode Vehicle Lane and Parking Assembly. Source: SmartCode v.9.2

FIG 26. Pedestrian Walkways and Street Views. Source: Graphic by Author

FIG 27. View of Park Bordering Sheppard Avenue East. Source: Graphic by Author

FIG 28. View of Park Entering from the North. Source: Graphic by Author

FIG 29. View of Green Space Connecting to Victoria Park Avenue.

Source: Graphic by Author 
FIG 30. View of Central Public Space. Source: Graphic by Author

FIG 31. View Approaching Central Public Space by Pedestrian Street.

Source: Graphic by Author

FIG 32. View of Central Public Space

FIG 33. View of Transit Stop on Sheppard Avenue East. Source: Graphic by Author

FIG 34. View of Transit Stop on Victoria Park Avenue. Source: Graphic by Author 


\section{Introduction}

To repurpose is to reuse for a different intention or to alter and to make more suited for a different function. ${ }^{1}$ To repurpose suburbia is to create a new environment within the existing suburban landscape. The thesis explores the reuse of the suburbs by recovering underdeveloped greyfield sites and "retrofitting", "reclaiming" and "reprocessing" them into new developments.

With the development of suburbia, cities and towns in North America have lost much of their capacity to support community. As one of millions of people who grew up in a stereotypical suburban environment - in a middle and upper-class area, with cars in the garage, excellent public schools and nothing much to do except hang out at the mall - I would not have chosen this life for myself. Architects and planners must recognize that despite its negative impact on society, "sprawl" (or greenfield development) still accounts for $75 \%$ of all new development. ${ }^{2}$

The form of many North American cities is coming under investigation by planners, critics and architects. The more or less systematic development of the suburbs was the big architectural project of the past century in North America. The densification and redevelopment of what is now being characterized as sprawl into something akin to an urban form - one that is connected and hospitable and brings a sense of belonging in society - will be the big project of the $21^{\text {st }}$ century. A new landscape is evolving, hybridizing and recombining urban and suburban patterns and practices to bring form to the suburban periphery. The suburban landscape includes an abundance of underutilized, dead or dying land with potential to be redeveloped and repurposed into a more urbane and high density fabric. This thesis explores the creation of high-density, diverse, mixed-use nodes that are connected to public transit to produce vibrant, urbane destinations. By intensifying existing low-density single-use infrastructure, the thesis proposes a partial antidote to sprawl.

Beginning with an examination of critiques of suburbia and an assessment of the different forms the suburbs have taken (on both greenfield and greyfield sites), the thesis will explore the possibility of repurposing suburbia from the inside out as a network of nodal developments on underutilized and inefficient land. Having grown up in suburban Toronto, l've chosen to examine suburban development in Toronto, and to look for ways to use greyfield sites

\footnotetext{
1 "Repurpose - Wiktionary." Wiktionary, the Free Dictionary. 7 Feb. 2010. Web. Sept. 2010. $<$ http://en.wiktionary.org/wiki/repurpose>.

${ }^{2}$ Ellen Dunham-Jones, and June Williamson. Retrofitting Suburbia: Urban Design Solutions for Redesigning Suburbs. Hoboken, N.J.: John Wiley \& Sons, 2009. pg. $x$.
} 
to support well-rounded, complete neighbourhoods. While the design portion of the thesis is somewhat site specific, the intention is to identify strategies and methods and targets that can be applied to similar sites throughout suburbs in North America.

Urban design and architecture should work hand and hand to create neighbourhoods and buildings that bring people together. The thesis explores the possibility of accommodating growth, and improving the quality of life in blighted areas within our EXISTING urban and suburban fabric. 


\section{Critiques of Suburbia}

\section{INTRODUCTION}

By understanding the critiques of suburbia permits the comprehension of its history and development through time. People say we are a product of our built environment - to grasp what this statement has meant for a majority of us currently living in, or for those who have grown up or lived in the suburbs in the past - this chapter describes the suburban effects on health, happiness, social interaction, community, family relations etcetera. It is only when we acknowledge the whole story can we realize what the future of the suburbs can hold.

Given that the suburbs are still relatively young in comparison to the greatest cities in the world; this chapter includes 2 subsections: Critiques Throughout the $20^{\text {th }}$ Century and Current Critiques. Critiques Throughout the $20^{\text {th }}$ Century encompasses the history of suburban development. Current Critiques comprises of current issues from the year 2000 onwards, and the change in thought and mentality of people. The transformation in thinking has not only prompted society's perception of the suburbs to change, but also is affecting where and the way we shape our built environment progressively in the new millennium. 


\section{CRITIQUES THROUGHOUT $20^{\text {TH }}$ CENTURY}

Society's anti-urban sentiment combined with government policies influenced the landscape and form of North America. The conception of suburbia and its many models have long been the answer to a nation's fulfillment of the North American dream. Additionally, the evolution of the suburbs with post WWII housing needs, and technological advancements led to postwar suburbs. Change in scale from pedestrian to automobile coinciding with the mass production of houses, as well as zoning regulations that separates and segregates every aspect of life characterize postwar suburbs. The description and critique of the suburban history below has not only affected the mindset of people but also the needs and desires of the populace at the time, and influenced the shape and form of the suburban landscape still prominent today.

Given that many people in the $19^{\text {th }}$ century and the beginning of the $20^{\text {th }}$ century worked in cities, sometimes under appalling conditions, the suburbs provided a comparatively light, green and tranquil living environment. Three trains of thought in modernism of cities led to the anti-urban sentiment: the belief that cities were bad because of crime, corruption, degrading human conditions, and fear; that cities were unhealthy - physically, socially, aesthetically and morally, and that cities go against good family life. Most of the criticism stemmed from the excessive crowding of too many people in too little space, the inability to live a long and healthy life, sanitation, and the inability to raise children in a 'safe' environment - linked to the belief that cities undermined religion and morality.

In the $19^{\text {th }}$ century, people began to move out of cities and into suburbs; the movement fuelled by the attractions of rural life, the yeoman ${ }^{3}$ experience as much as a rejection of urban life. Intellectuals like Poe, Melville, and Hawthorne thought that the "city scene was the backdrop for frightening experiences, personal defeat, icy intellectualism, heartless commercialism, miserable poverty, crime and sin, smoke and noise, dusk and loneliness." ${ }^{\prime 4}$ The creation of streetcar suburbs and railroad suburbs around the $20^{\text {th }}$ century led to the migration of people becoming widespread among all classes. The extension and availability of public transportation meant that more land was available at lower land costs in newly developed suburban districts - enabling the worker to live away from the area of his workplace. Robert Fishman states, "The city was not just crowded, dirty and unhealthy; it was immoral. Salvation itself depended on separating the woman's sacred world of family and children from the profane

\footnotetext{
${ }^{3}$ Yeoman: A farmer who cultivates his/her own land, is below the gentry class

${ }^{4}$ Tom Martinson. American Dreamscape: the Pursuit of Happiness in Postwar Suburbia. New York: Carroll \& Graf, 2000: 17 .
} 
metropolis." Furthermore, Lewis Mumford explains, "What only kings could demand once, was now the prerogative of every commoner who could get hold of the land itself."

The continued concerns of population concentration meant that decentralization was the counter attack to urbanity. President Roosevelt's 1930s Resettlement Administration was committed to sprawl as a means of recovering from the Great Depression. In the mid $20^{\text {th }}$ century, sprawl was good for North Americans. Academics claimed that the criticism about suburbia was largely misplaced; arguing that sprawl was the new normal - that it was economically successful given that millions of suburban homes were purchased meant that the public approved its creation, and met their expectations and desires. Henry Ford summed up the anti-urban attitude in his pitch for the automobile when he said, "we shall solve the City Problem by leaving the city." The American anti-urban sentiment also spilled over into Canada and throughout time has spilled over into other nations around the world. Since urban growth happened in the periphery of the city, the suburbs became identified with the spreading of city, and were no longer a refuge from the city itself.

In 1934, the NHA (National Housing Act) of Canada regulated the rates of interest and the terms of every mortgage enabling consumer desire to become consumer demand, raising home ownership from $44 \%$ in 1940 to $66 \%$ in 1990s. The NHA had the dedication not to build communities or neighbourhoods but to build houses. Similar to the NHA, in the United States there was Federal Housing Administration. Humphrey Carver, one of Canada's most influential planners during the mid- $20^{\text {th }}$ century, described that the technological revolution put the family in a car and the social revolution gave the family a house in the suburbs. ${ }^{7}$ Not only did the two revolutions scatter and fragment cities, but also through these revolutions, people won freedom and individuality, space and privacy; however, the benefits were at the expense of other values that led to the disappointment of the suburbs. Lewis Mumford describes that "suburbia offers poor facilities for meeting, conversation, collective debate, and common action - it favours silent conformity, not rebellion or counter-attack." ${ }^{\prime 8}$ The legislation of the National Highway Act in 1956 by the United States, with a similar act passed in Canada, further encouraged developers and merchant homebuilders to seek sites farther from the city centre. Mumford goes on to say that "as soon as the motor car became common, the pedestrian scale of the suburb disappeared

\footnotetext{
${ }^{5}$ Robert Fishman. Bourgeois Utopias: the Rise and Fall of Suburbia. New York: Basic, 1987: 38.

${ }^{6}$ Lewis Mumford. The City in History. London: Penguin, 1961: 488.

${ }^{7}$ Humphrey Carver. Cities in the Suburbs. [Toronto]: University of Toronto, 1962: 12.

${ }^{8}$ Lewis Mumford. The City in History. London: Penguin, 1961: 513.
} 
and with it, most of its individuality and charm. The suburb ceased to be a neighbourhood unit: it became a diffused low density mass."

When mass production of the automobile began, it was boasted to help form community life by combining the best of city and country living. The automobile suburb did not put people in natural surroundings, nor did it have characterized diversity of relationships and experiences found in cities. The typical suburb built after World War II, lacked the advantages of both the city and country life far more than it incorporated them. Henry Ford did not anticipate that city planning would make the car more important than the people. The change in planning coincided with single-use planning, surrendering the streets to the cars, and the residential sterility imposed by negative zoning that separated functions and fragmented the city. The automobile was the catalyst that made haphazard planning possible affecting the scale of the city and neighbourhood.

Between the 1950s and 90s North American growth was characterized by mass suburban development, wide spread road building, increased car use, congestion and pollution, and typified by abundant consumption and communal conformity. People want to live in suburbia but constantly complain about road rage, rising taxes, municipal debt, crime, loss of open space, lack of affordable housing, and out-of-control development. Robert Fishman, in the book entitled Bourgeois Utopias, commented, "suburbia was at once the most characteristic product of explosive urban expansion and a desperate protest against it." ${ }^{10}$ Fishman notes that the rapid growth of suburbia made it seem as though suburbanization had begun in 1945, when in fact suburbia had been occurring for a century. The railroad and streetcar suburbs built in the $19^{\text {th }}$ century and the first half of the $20^{\text {th }}$ century were not characterized by the same stereotypes as more recent ones. $70 \%$ of the houses built in 1949 were built by only $10 \%$ of the builders ${ }^{11}$ explaining the monotonous uniform form of houses that often are associated with suburbia.

Humphrey Carver discussed how great emphasis placed upon the individual as a member of the family rather than as a member of society ${ }^{12}$ illustrated by the devotion of home ownership. The search for an affordable single family home forced people to move away from the old city centre to the periphery/edge. Lewis Mumford in The City in History describes:

"While the suburb served only a favoured minority, it neither spoiled the countryside nor threatened the city. But now that the drift to the outer ring has become a mass movement, it tends to destroy the value of both environments

\footnotetext{
${ }^{9}$ Lewis Mumford The City in History London Penguin, 1961505

${ }^{10}$ Robert Fishman Bourgeors Utopias the Rise and Fall of Suburbia New York Basıc, 1987206

${ }^{11}$ Ellen Dunham-Jones, and June Willamson Retrofitting Suburbı: Urban Desıgn Solutions for Redesigning Suburbs Hoboken, NJ John Wiley \& Sons, 200917

${ }^{12}$ Humphrey Carver Cities in the Suburbs. [Toronto] University of Toronto, 196267
} 
without producing anything but a dreary substitute, devoid of form and even more devoid of the original suburban values."

The suburbs were supposed to be a way of life that offered free expression of the individual. Instead, the modern suburb has stereotyped houses in a monotonous, standardized environment where everyone has the same everything. John Keat's, a popular critic of suburbia wrote in his book The Crack in the Picture Window that

"The typical postwar development operator was a man who figured how many houses he could possibly cram onto a piece of land... Then up went the houses, one after another, all alike." 13

Rarely achieved was the ideal of the North American dream in the postwar period where the suburbs housed millions of North Americans. There is a perception by suburbanites that something is missing and that casts aggravation; people say there is nothing to relate to and that there is no destination. Gertrude Stein remarked, 'there is no there there', commenting on the "placelessness" and the lack of "authenticity" that characterizes many North American cities, more specifically the suburbs, similar to what James Kunstler calls 'the geography of nowhere.' The dissatisfaction with the suburbs is very much due to the absence of memorable places that give meaning and expression to city life. David Riesman describes the suburbs as "aimlessness, a pervasive low-keyed un-pleasure which cannot be described in terms of traditional sorrows."14

\section{CURRENT CRITIQUES}

The $20^{\text {th }}$ century suburb was planned and developed around zones of single activity. In contrast, the $21^{\text {st }}$ century has thus far been a time of change. This section discusses the effects of suburban sprawl on the health and wellbeing of the nation, as well as explains how the suburbs have altered and morphed over the years - creating a less suburban landscape. Furthermore, the new millennium has transformed the perception and outlook of the North American dream. The change in mentality and demographics that shape society is continually influencing where and how suburbia and the city are developing.

In 2000 , the U.S. census data confirmed that $50 \%$ of the population was living in urbanized areas outside of central cities - in suburbs - about 140 million suburbanites at the time. ${ }^{15}$ Low-density residential areas, affluent and middle class residents, home ownership, and

\footnotetext{
13 John Keats. The Crack in the Picture Window. Boston: Houghton Mifflin, 1957: xiv.

${ }^{14} \mathrm{~S}$. Saunders. Sprawl and Suburbia. Minneapolis, MN: University of Minnesota, 2005: 21.

${ }^{15}$ Ellen Dunham-Jones, and June Williamson. Retrofitting Suburbia: Urban Design Solutions for
} 
long commutes to work characterizes suburbia. Today it is not uncommon for critics to flatly state that the suburbs have "failed," the assessment is massed on the definition of what a suburban "success" is - a suburb that looked a lot like an urban neighbourhood" ${ }^{16}$ a dense, compact, mixed-use pedestrian-friendly community. "None of the places for casual and spontaneous interaction which create vital neighbourhoods" exists in the suburbs. ${ }^{17}$ In scale and in demographics the suburbs are now the principal focus of North American society. Critics believe that the isolation within suburbia leads to the unhappiness of its inhabitants. Intellectuals criticized the lack of cultural nourishment in the suburbs as it compared to urban centres. Other critics worried that "passivity, mechanization, and commercialization of leisure would prove to be just one more link in the chain of suburban tyranny." ${ }^{18}$

Within North America, suburban sprawl is now the standard form of growth that ignores all historical precedent and human experience. Unlike the traditional neighbourhood model ${ }^{19}$ that evolved organically in response to human needs, suburban sprawl is an idealized, artificial system, and an unhealthy form of growth. Andres Duany author of Suburban Nation argues that suburban sprawl is a direct result of a number of policies that conspired to encourage urban dispersal, most significant being the Federal Housing Administration and Veterans Administration, or the National Housing Act in Canada ${ }^{20}$ discussed in the above section. Sprawl is the uncontrolled expansion of low-density, single-use, and automobile dominated suburban development that spreads thinly over former agricultural land in an irregular fashion. In the present, it is the single most significant and urgent issue in North American land use. People continually are moving out into the exurbs ${ }^{21}$ than are moving into the now vibrant and safe core. The benefits of a home with a lot of space and privacy, still count more than the benefit of being able to walk to get bread. People believe that it is more convenient, healthier, and better to live out in the exurbs and suburbs.

Literature holds urban sprawl responsible for much of what is wrong with American and Canadian urban fabric. Libertarians and others opposed to government restrictions on property rights feel the effort to control sprawl is an elitist attack on the American Dream that withholds

Redesigning Suburbs. Hoboken, NJ: John Wiley \& Sons, 2009: 16.

${ }^{16}$ Hitchcock, John. Neighbourhood Form and Convenience: a City-Suburban Comparison. Canada: University of Toronto, 1981: 138.

${ }^{17}$ IBID, 180.

${ }^{18}$ Nicholas D. Bloom. Surburban Alchemy. Columbus: Ohio State UP, 2001: 11.

${ }^{19}$ Traditional Neighbourhood: mixed-use, pedestrian-friendly communities in varying population either as free standing as villages or clustered in towns and cities; it is a form of sustainable growth.

${ }^{20}$ Andres Duany, Elizabeth Plater-Zyberk, and Jeff Speck. Suburban Nation: the Rise of Sprawl and the Decline of the American Dream. New York: North Point, 2000: 7.

${ }^{21}$ Exurb: composed of tract housing where the suburban fabric make people auto dependant. 
the dream from those who are still trying to fulfill it. The title of Robert Putnam's book Bowling Alone implies the privation of group activity as an outcome of living a sprawled life. What changed since the $20^{\text {th }}$ century is the number of sprawlers and scale of sprawling. Two million acres of farmland and open space is continually to be lost to development every year in the United States alone. North Americans currently use the equivalent of ten acres of land per capita, whereas less developed countries use approximately one acre per capita.

The suburbs built since World War II has made people vulnerable to the pressures of modern life. Suburbanites have less personal time due to longer work hours and time spent commuting. What draws people to suburbia are lower housing costs with the hope of eventual appreciation, however the costs of infrastructure building, energy generation, and pollution tend to be costly to society.

Doctors believe that suburbia promotes an unhealthy way of life. Coincidently, the moment when the United States became mainly a suburban nation, it began to suffer from individual trauma, family distress, and civic decay; the same happened in Canada. Moreover, as Philip Langdon describes in A Better Place to Live: Reshaping the American Suburb, the contaminants of the suburbs are: the economy with jobs that are unfulfilling, the costliness of American life meaning the assumption that if you do not buy expensive goods than you are a failure, the insecurity of work and pay, the influence of marketing and advertising in American life meaning buy or be incomplete, the distressing news and information from mass media, and the entertainment industry.

Typically, people believe that the suburbs are healthy environments meant for bringing up children. However, are they? Children are suffering from the imbalances and disconnection associated with the suburbs just like adults. A study by psychologist Nicholas Zill found that $10 \%$ of children between the ages of $12-16$ are frequently lonely. ${ }^{22}$ The loneliness soars in the teenage years. Suburbia creates many conditions that effect children in worse ways. Edward Shorter, a medical historian, found that people in North America have more medical complaints than a few decades ago, especially physiological complaints. ${ }^{23}$ He believes that one reason for the increase is the decline in the number of individuals per household. Moreover, social scientist Amitai Etzioni discusses the importance of community to individuals, without it, they are diminished. Etzioni further states: "A basic observation of sociology and psychology is that the

\footnotetext{
${ }^{22}$ Philip Langdon. A Better Place to Live: Reshaping the American Suburb. Amherst: University of ${ }^{23}$ IBID, 20.
} 
individual and the community 'make' one another, and that individuals are not able to function effectively without deep links to others, to community." ${ }^{24}$

Recently, public health researchers have recognized the negative impact edge city and sprawl have on human health. Dr. Howard Frumkin and Dr. Lawrence Frank professors at the University of British Columbia, documented the wide range of health effects related to living in sprawl including: impact of car emissions, accident rates, social isolation, and reduced levels of inactivity. ${ }^{25}$ They note that the percentage of obese Americans more than doubled from $15 \%$ to $31 \%$ between 1980 and 2000, meanwhile the amount of hours the average American spent driving also more than doubled in the same period. ${ }^{26}$ The stress level of people continually increases; anxiety, depression, and Attention Deficit Hyperactivity Disorder (ADHD) are all on the rise, leading people to use pharmaceutical drugs increasingly rather than living in healthy, sociable communities. Furthermore, research shows that people who live in walkable neighbourhoods have lower body mass indexes on average than those in non-walkable neighbourhoods. ${ }^{27}$ The suburbs are not healthy places to raise a family as commonly perceived, nor are cities unhealthy.

In North America, the segregation that only applied to incompatible uses now applies to everything. The resultant landscape does not look like a place, feel like a place, and does not act like a place. Planned subdivisions did not incorporate services or transit into the plan, assuming that only people with automobiles would be living there, fostering homogeneity rather than diversity. The poor, elderly, handicapped, young people and anyone else who could not or did not drive needed to live elsewhere. The average household currently generates 13 car trips per day caused by all the segregation and zoning policies against different uses being near each other. ${ }^{28}$ Land taxation should encourage urban consolidation rather than urban sprawl. Currently, some land taxes actually promote urban sprawl pushing for an increase rather than a decrease of car use, and leading to inner-city neglect and social decay. Taxes should penalize schemes that generate levels of social segregation, congestion, and pollution. ${ }^{29}$ Furthermore,

\footnotetext{
${ }^{24}$ Philip Langdon A Better Place to Live Reshaping the American Suburb Amherst University of Massachusetts, 199421

${ }^{25}$ Howard Frumkın, Lawrence D Frank, and Richard Jackson Urban Sprawl and Public Health Desıgning,

${ }^{26}$ IBID Planning, and Buldıng for Healthy Communities Washıngton, DC Island, 2004

${ }^{27}$ Reıd Ewıng "Relationshıp Between Urban Sprawl and Physıcal Actıvity, Obesıty, and Morbıdıty " American Journal of Health Promotion 181 (2003)

Lawrence Frank, Martın Andresen, and Tom Schmıdt "Obesıty Relatıonshıps with Communıty Desıgn, Physıcal Activity, and Time Spent in Cars " American Journal of Preventive Medicıne 272 (2004)

${ }^{28}$ Andres Duany, Elizabeth Plater-Zyberk, and Jeff Speck Suburban Nation the Rise of Sprawl and the Decline of the American Dream New York North Poınt, 200022

${ }^{29}$ Rıchard George Rogers, and Philıp Gumuchdjlan Citıes for a Small Planet London Faber and Faber,
} 
urban sprawl and the separation of functions leave parts of the city dead on weeknights and weekends which is a waste of infrastructure and not good for businesses. An integrated design of mixed-use infrastructure would prevent areas from having dead times.

Unlike earlier life lived largely outdoors in direct contact with nature, nature in the industrial age consists of lawns, street trees, and public parks, a tendency by human settlement to suppress nature. Postwar zoning has eliminated essential gathering places or have displaced them to remote locations thus nullifying community building. Although, some people prefer to live like hermits, nowadays subdivisions are built as if everyone wants to live like hermits. To many contemporary Americans, community seems more like an optional pleasure than a civic obligation. Society's obsession for privacy matches with its concern for safety. The more privatized we become, the concern for security and safety rises. Alarms, fences, gates, setbacks, protective lighting, and landscaping are all physical indicators that people are barricading themselves in and security is tightening. The desire for greater security is seen in the increased demand for gated communities around the world following the trend in the United States. ${ }^{30}$

Corporate chains could not have achieved their size and success if it had not been for zoning policies that prohibited commercial establıshments in residential developments. Zoning effectively flocks people from miles away into strips, and shopping centres. The purging of residential neighbourhoods not only erased small retail operations, but also anything that might have amused, attracted or brought people in contact with one another. There is a definite relationship between local commercial establishments and the neighbourhood sociability being very strong. Today consumption lies heavily on ordinary architecture from single-family houses to big box stores and office parks. The priority of technological innovation is now efficiency, where artificial materials make up most of new construction because it reduces assembly and first costs. Retail business goals for greater market share and increasing selection leads to larger buildings. The average supermarket dimensions have leaped from 10,000 square feet 25 years ago, to 50,000 square feet today..$^{31}$ In newer parts of the city, the huge dimensions of box retail mesh with the scale of industrial parks, airports, and the interstate.

The North American dream in the past was about succeeding in your career, giving chıldren better opportunities than you had, and owning a home. Dolores Hayden observes the

1997158

\footnotetext{
${ }^{30}$ Paul Kelbie "Rise in Gated Communities Could Pose a Threat to Public Services " The Independent 27 Sept 2003 Web 4 Apr 2011 <http //www independent co uk/lfe-style/house-and-home/property/rise-Ingated-communities-could-pose-a-threat-to-public-services-581318 html>

${ }^{31}$ Willıam S Saunders. Spraw/ and Suburbıa Mınneapolıs, MN Unıversity of Mınnesota, 200580
} 
reshaping of the North American dream; the dream of the ideal house replaces the importance of community crucial to our establishment as a nation. ${ }^{32}$ The ultimate aim of this dream is to own not just any home anywhere, but the dream home, an emblem of freedom and individualism. Hayden points out that never before has the vision of people been vastly focused on anything as small as a house. ${ }^{33}$ People invest more into their home and private land to feel like they are fulfilling their hopes and dreams, as if the house can substitute all that community offers. As Richard Goodwin declared, "there is virtually no place where neighbours can anticipate unplanned meetings - no pub or corner store or park."34 North Americans especially in the United States have the largest houses in world. There is a need for space to contain and store all the stuff of recreation, consumption, and entertainment which our society invests heavily in to establish a certain image or status in the community. The "stuff" also compensates for the lack of shared recreation in the neighbourhood. Hence, we have over-equipped houses in underequipped neighbourhoods. Moreover, real estate agents suggest three of the most important factors in purchasing a home is location, location, location, yet to some people location is not a priority as much as the number of bedrooms, the finishes, and the size of the home. Houses can always be altered, additions built, but the attributes of the community around the house are largely beyond individual control. The decline of community is a recurrent theme in North American commentary for most of the century, only recently has bad community planning been blamed for our current outcome. One needs to think of the broader context of community before thinking about a particular house within it.

There were approximately 1 billion cars in the world by 2010 that number will double by $2030 .^{35}$ The wider cities sprawl, the more uneconomic it is to expand public transportation systems, and the more car dependant citizens become. In Jane Holtz Kay's book entitled Asphalt Nation, she discusses that commuting to work typically involves only $20 \%$ of auto use, and she characterizes 2/3 of our auto use and trips as allowing us to "consume, survive, and fraternize." ${ }^{36}$ Travel by car is currently cheap but that is because the taxpayer subsidizes it, as Kay explains the cost of owning a car is a minimum $\$ 6,000$ to the owner and $\$ 3,000$ to society per year. ${ }^{37}$ The indirect costs of motoring simply never reflect in the cost of cars and petroleum,

\footnotetext{
${ }^{32}$ Richard Sexton. Parallel Utopias: the Quest for Community : the Sea Ranch, California, Seaside,

33 IBID, 159

Florida. San Francisco: Chronicle, 1995: 159

34 IBID, 7.

${ }^{35}$ Richard George Rogers, and Philip Gumuchdjian. Cities for a Small Planet. London: Faber and Faber, 1997: 35.

${ }^{36}$ Tom Martinson. American Dreamscape: the Pursuit of Happiness in Postwar Suburbia. New York: Carroll \& Graf, 2000: 106.

37 IBID, 106.
} 
such as building and maintenance of roads, subsidies for company cars, long-term damage caused by pollution, disruption of the local community, and ill health. From 1982-2000 the United States population grew $19 \%$, but the percent of the time people spent stuck in traffic grew $236 \%$. $^{38}$

There is an imperative to design the suburbs in a harmonized approach to transportation, employment, shopping and services to create compact and walkable places. People in bedroom suburbs and older cities want more walkable neighbourhoods; they are tired of growth that makes a region bigger without making it better. According to Richard Rogers, the challenge we face is the move from a system that exploits technological development for pure profit, to one that has sustainable objectives. ${ }^{39}$ Making cities and suburbs sustainable demands fundamental changes in human behaviour, in government practice, commerce, architecture and city planning. Suburbs have become parasites on the landscape, a huge organism that is draining the world. There needs to be interplay of economic, social, and environmental factors in planning to create a sustainable environment that embraces complexity and rejects current zoning.

Suburban households increasingly reflect the changing demographics of Canada where for the first time in Canadian history, the 2006 Census data reveals that $43 \%$ of census families were couples who did not have children, compared to $41 \%$ who were couples with children. Contrasting the above statistics to 30 years ago, couples with children (nuclear families) represented over $50 \%$ of all family types. ${ }^{40}$ Furthermore, household size has also been declining over the past century. In 2006, there were more than three times as many one-person households (27\%) as those consisting of five or more people (9\%). Additionally, for the first time in Canadian history, the 2006 census showed that there were more unmarried people in Canada than legally married people, this illustrates that there is a decline in people getting married in general. ${ }^{41}$ These statistics reflect a social indication that the suburbs no longer have as much relevance as they might have had in the baby boom years. The suburbs are not as "suburban" as they used to be with their characterized nuclear families, however people do not have to have a spouse and kids to participate in the yeoman and working class suburbs;

\footnotetext{
${ }^{38}$ Tom Martinson. American Dreamscape: the Pursuit of Happiness in Postwar Suburbia. New York: Carroll \& Graf, 2000: 109.

${ }^{39}$ Richard George Rogers, and Philip Gumuchdjian. Cities for a Small Planet. London: Faber and Faber, 1997: 38.

${ }^{40}$ Statistics Canada. 2007. Family Portrait: Continuity and Change in Canadian Families and Households in ${ }^{41} \mathrm{IBID}, 6$. 2006. Statistics Canada. Catalogue no. 97-553, Ottawa: 9.
} 
whether married, single, or an empty-nester the evolving suburban environment must reflect and change to suit its new occupiers.

North America is passing through a major demographic transition. Some of the changes are that we have fewer children, increased female participation in the work force, an older population as the baby boomers retire, and a smaller household. These changes increase the cost of social services, transport, and energy. Furthermore, over the next decade, two generations of North Americans - baby boomers and Generation $X^{42}$ will both seek out urban lifestyles, creating a demographic demand for urban living. ${ }^{43}$ Over the next century, they will become a powerful societal force, voting and buying real estate, having sustainability and practicality in the core values, and expect sustainability to be a part of their consumer and lifestyle choices. Their buying power is already driving the market to provide sustainable urbanism, with increasing numbers of projects combining new urbanism and green building. Now grown Baby Boomers and Generation $X$ raised in the suburbs are eager to get out and explore city life, which has made the demand for downtown housing and housing in urban areas high.

Boredom and isolation are by no means the only reasons the re-urbanization will have to increase. The age of cheap, abundant oil is winding down in the next 20 years or so. As driving becomes more expensive, the land pressures will increase, and many well-distributed nodes that offer the necessities of work, play, shopping, and services combined in layers of program will support people, and to create local economies. The suburbs will urbanize and cities will continually densify. As Ellen Dunham-Jones discuses, in the past quarter of a century the landscape produced is without any kind of buildings that architects would consider real "architecture." Most architectural designers shun $75 \%$ of all new construction in recent decades. ${ }^{44}$ Architects and architectural scholars point to an un-designed sprawl of suburbia and say "don't blame us; we had nothing to do with it." 45 This avoidance is exactly the problem. Homebuilders or small contractors continually build houses that are more and more alike with only minor variations on the same free plans. Stand-alone retail franchises, hotels, and storage facilities rely on standardized templates. Bias against suburbia disengages architects from the environment in which nearly half of North Americans now live and work. Architects, landscape architects, urban planners and designers must move beyond their almost total fixation with special and singular construction to work for the improvement of the general condition of sprawl,

\footnotetext{
${ }^{42}$ Generation X: are those born between 1977 and 1988 that have been raised with recycling and other environmental values.

43 Douglas Farr. Sustainable Urbanism Urban Design With Nature. New York: Wiley, 2007: 53.

44 IBID, 1.

${ }^{45}$ S. Saunders. Sprawl and Suburbia. Minneapolis, MN: University of Minnesota, 2005:3.
} 
of average normative buildings. Suburban development is opening up new opportunities for architects to tackle dilemmas affecting the suburban landscape, to produce innovative potentially critical architecture.

\section{CONCLUSION}

The goals of creating more diverse, life enriching, sound urban environments will ultimately depend if North Americans can find ways to look past their personal short-term selfinterest towards long-term social value. At a certain point in the coming decades, there will be no choice, and people's outlook and self-interest will need to change for civilization to continue to function. It is only by understanding the history, the issues, and concerns about the suburbs, that one can successfully and logically move to create something relevant to society in the 21st century. 


\section{Precedents}

\section{INTRODUCTION}

Architects, planners, and designers have been attempting to create a better place to live for over a century. However, no matter how much planning goes into a given development it does not guarantee a success. Things do not always turn out as planned and perceived on paper, and policies produce unintended consequences. Most of the examples below are preplanned projects built and modeled on greenfield sites, as opposed to retrofitting or repurposing that takes place on greyfield sites. Two trains of thought in the $20^{\text {th }}$ century saw the answer to overcrowded cities in different ways. Ebenezer Howard and followers believed that it was crucial to depopulate the city by constructing complete communities out in the countryside - Garden Cities or New Towns were their answer. Le Corbusier saw the solution to city woes from within the city itself by developing high-rise and high-density living and working that opened up the ground plane - moving vertically instead of horizontally. Clarence Perry and Clarence Stein, show the significance of planning and designing at the neighbourhood scale as a means for building the bigger picture of the district, town, or region. In the postwar era, Victor Gruen believed that shopping malls could emulate the qualities of communities and main streets in an enclosed consumer area. Additionally, contemporary movements have been inspired from past theories that translate concepts into relevance moving towards the future. It is only when we collectively combine key characteristics and concepts are we truly creating a holistic, repurposed suburbia. 


\section{TYPES OF LAND DEVELOPMENT}

Generally, there are three types of land development: greenfield, greyfield, and brownfield. Greenfield is undeveloped open land; greyfield is previously developed land that is underutilized or underdeveloped, whereas brownfield describes contaminated land. The scope of this thesis will only focus on greenfield and greyfield land development. It is important to realize that suburban development thus far has mainly taken place on greenfields. That being said the interest in this thesis focuses on redeveloping greyfield land as a means for retrofitting or repurposing suburban sites. The current century should be a time when greyfield repurposing is the primary form of land development.

\section{GREENFIELD SITES}

Suburban developments have typically materialized on greenfields that appear more directed to making the suburbs "a better place to live," than revitalizing decaying urban cores or inner ring suburbs. Public and private builders prefer single-function buildings; they prefer major projects on large open sites or cheap greenfield land. Greenfield land acts as a moldable blank canvas, and offers the possibility of constructing planned whole housing estates or business parks with minimal leasehold or complications. These sites allow for maximizing on standardization of design and construction (mass-production) leading to cost effectiveness and a case against mixed-use. Mixed-use development typically has buildings of various heights and those over five stories trigger a different building-code that requires extensive fire, safety, and ventilating standards. Buildings that house more than one use must accommodate additional entrances and exits, parking systems and wall separation. However, by building at a higher standard of building-code allows ease in transformation of use later. Developers search for short-term profit and quick results and continue to turn investment away from complex mixed-use urban development and its innate social and environmental benefits. ${ }^{46}$

\section{GREYFIELD SITES}

As people move farther away from central cities in search of cookie cutter houses, extensive lawns and garages, with bigger and brighter box stores and malls, it leads to the decline of older suburbs. Communities are left with decaying sites creating holes in the landscape - these sites are known as greyfields. Although, the book Greyfields to Goldfields: Dead Malls Become Living Neighborhoods characterizes a greyfield as a dying mall, the

\footnotetext{
${ }^{46}$ Richard George Rogers, and Philip Gumuchdjian. Cities for a Small Planet. London: Faber and Faber,
} 1997: 35 
meaning can also apply to other types of dying, dead, abandoned sites or land that is inefficiently used and underdeveloped. One-time community assets are underutilized and suffering from disinvestment; these eyesores are symbols of a deeper-rooted pattern of haphazard development, and regardless of size, the property represents an opportunity to reinvigorate a community. Modern day 'ruins' can take the shape of many common suburban forms such as regional malls, residential subdivisions, garden apartments, golf courses, commercial strips, big box stores, and industrial and office parks, all of which can be transformed to integrate rather than isolate uses and regenerate abandoned sites to create a connected network of urban neighbourhoods. Arthur $\mathrm{C}$. Nelson, a professor of planning and codirector of Virginia Tech's Metropolitan Institute argues that since suburban retail sites tend to become obsolete after 15 years a large number of greyfields will be ready for redevelopment in less than a quarter century. Nelson estimates 2.8 million acres of greyfields will be available for redevelopment in America alone. ${ }^{47}$

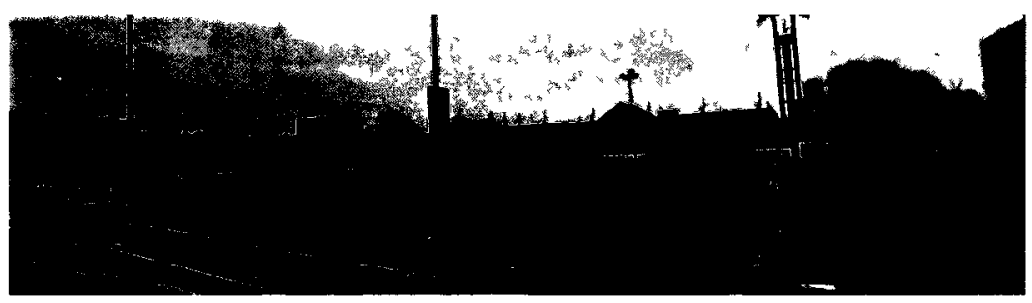

Figure 1: Greyfield site in Toronto

One of the most significant types of greyfields is shopping malls that have been dying since the late 1980s, and are dying faster than being newly constructed. The death of shopping malls is mainly due to major department stores (the anchor) closing from declining sales and wasted space leading to the decline of other retailers. It is very unlikely that the structure will ever serve as a conventional shopping mall again. Greyfield malls offer fertile landscape to change use, most of these centres and their parking lots comprise of huge land parcels near or at strategic crossroads. Another example of greyfields are high-rises that typically sit on acres of underutilized land largely relegated to surface parking and mostly surrounded by chain link fences. Allowing new development to surround existing high-rises will offer a financing means for retrofitting the site by providing the social and community amenities needed in these districts. Unfortunately, current zoning is out of date and in most cases do not allow for mixed-uses; the time has come to update zoning to suit our current needs.

\footnotetext{
${ }^{47}$ Robert Steuteville. "Market Trends Favor NU." New Urban Network. 1 Apr. 2007. Web. 04 Apr. 2011. <http://newurbannetwork.com/article/market-trends-favor-nu>.

Arthur C. Nelson. "America Circa 2030: The Boom to Come." Architect October (2006).
} 


\section{ATTEMPTS TO DO SUBURBIA DIFFERENTLY}

\section{GARDEN CITY AND NEW TOWNS}

Ebenezer Howard in the late $19^{\text {th }}$ century and beginning of the $20^{\text {th }}$ century believed that the answer to overcrowding in cities was to depopulate and create completely new communities in the countryside connected to the main city via transit. The evolvement of his theories and ideas has influenced preplanned towns and communities on greenfield sites to this day, and are examined in this section.

Ebenezer Howard's prime contribution to planning was to outline the nature of a balanced community and to show what steps were necessary in an ill-organized and disoriented society to bring balance. He published his ideas in the book entitled Garden Cities of Tomorrow in 1902, and was recognized as the first person to attain and explain a comprehensive and logical vision of urban growth. His ideas led to Greenbelts, Garden Cities, Satellite Towns, Land Assembly, as well as neighbourhood and regional planning. He believed that city growth should take the form of satellite towns thrown into greenfields. A Garden City form is 1,000 acres at the centre occupied by the city itself, and 5,000 acres forming the agricultural greenbelt. The satellite town had a maximum population of 30,000 people, equaling 30 people per acre. ${ }^{48}$

The purpose of the Garden City was not to make suburban extensions contributing to sprawl, but to make a physical separation between the parent city and the satellite towns. By locating the Garden Cities on remote sites, it gave opportunities to design model communities that had densities greater than those generally acceptable. In reality, Howard points out that there was not only two ways of living: town life and country life, but the third alternative being the advantages of both town and country in combination - a Garden City. ${ }^{49}$ Town and country were the two magnets striving to draw people, married together.

"Thorough sanitary and remedial action in the houses that we have; and then the building of more, strongly, beautifully, and in groups of limited extent, kept in proportion to their streams and walled round, so that there may be no festering and wretched suburb anywhere, but clean and busy street within and the open country without, with a belt of beautiful garden and orchard round the walls, so that from any part of the city perfectly fresh air and grass and sight of far horizon might be reachable in a few minutes' walk. This the final aim."

\footnotetext{
${ }^{48}$ Ebenezer Howard, and Frederic J. Osborn. Garden Cities of To-morrow. London: Faber and Faber, 1960: 34 .

${ }^{50}$ John Ruskin. Sesame and Lilies. New York: Chelsea House, 1983.
} 


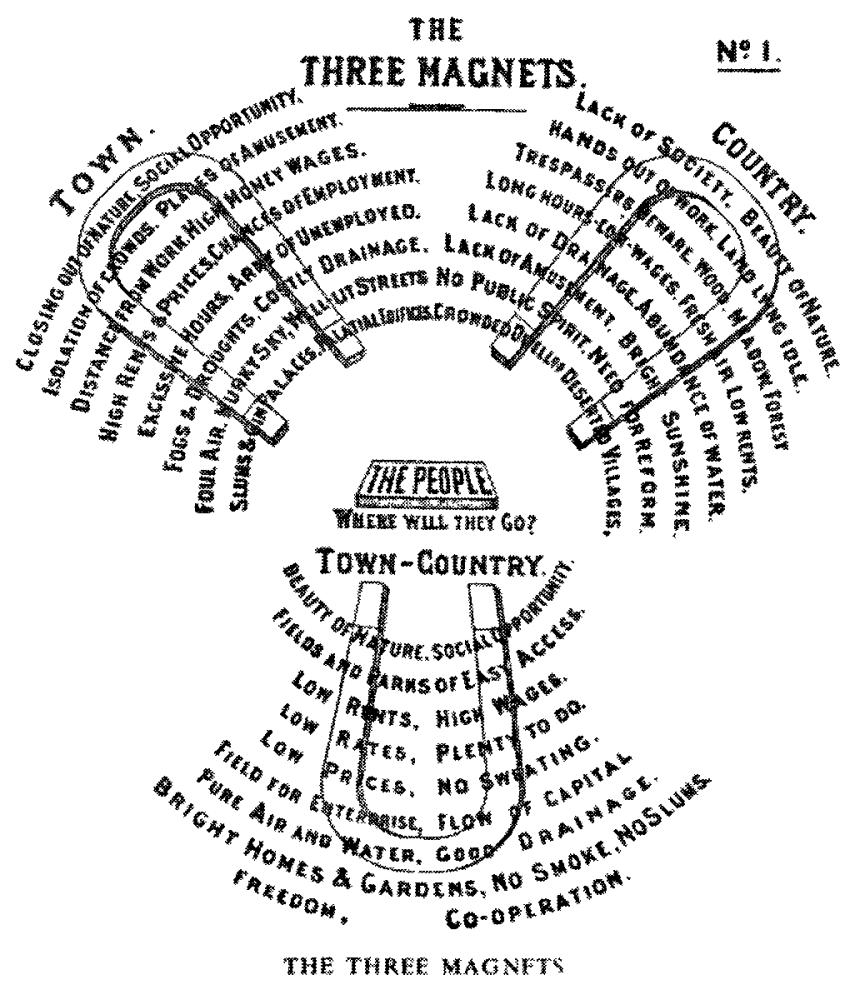

Figure 2: The Three Magnets

When a Garden City reached a population of 30,000 it did not continually build out on agricultural land, because that would defeat the purpose of the agricultural zone. This phenomenon of building out on agricultural land is the outcome of our present towns and cities, where private individuals are eager to build out on available agricultural land. Garden Cities grow by establishing another city, a distance beyond its own zone of 'country', so that the new town could also have a 'country' zone. The inhabitants of one could reach the other in a few minutes through rapid transit, and in reality, the people of the two towns represent a community. The principle of growth was always preserving a belt of country. The first practical application of Ebenezer Howard's Garden City was Letchworth designed by Parker and Unwin in 1903; it was located 34 miles from London. ${ }^{51}$ Letchworth captured the essence of Howard's vision with greenbelts for agriculture and nature, commercial and civic town centres, and a range of picturesque housing types.

\footnotetext{
51 Peter Geoffrey Hall. Cities of Tomorrow: an Intellectual History of Urban Planning and Design in the Twentieth Century. Oxford, UK: Blackwell, 2002: 96.
} 
After World War II, a modern European New Town movement began. Governments seized on the new town concept as a way to erase the memories of war, by rebuilding and decentralizing older urban centres to improve life for the average person. A New Town was a planned community designed from its inception, and was typically constructed on a greenfield. Europeans aimed to create a mixture of residential, commercial, cultural, and industrial activities in freestanding new communities. The New Towns Act of 1946 coupled with the Town and Country Planning Act of 1947 prohibited private land development, and represented a push for new alternatives to sprawl. New Towns had balanced growth and development by creating opportunities of employment to ensure that they would not turn into bedroom communities. An appropriate balance of self-sufficiency and connection was necessary for the new towns to exist next to large urban centres.

The first British New Town under the New Towns Act was Stevenage that treated clusters of residential communities as independent neighbourhoods; each organized around primary and secondary schools and a shopping area. The town centre at Stevenage served as the central connection between the residential communities and the industrial zone. ${ }^{52}$ The overall community plan incorporated business, entertainment, and civic uses. The town centre completed in 1967 was famous for being the first centre of a modern town that was completely a pedestrian precinct, whose middle incorporated shops and a small square connected to the bus station. $^{53}$ Furthermore, the towns' proximity to the central train station made commuting to and from London convenient.

Harlow was another example of a British New Town designed in 1947 to ease overcrowding in London after World War II. The town had divided into self-supporting neighbourhoods each with their own sub-centres, shops, community facilities, schools and church. Some of the centres in Harlow both separated and connected the neighbourhood clusters by providing some industry, ${ }^{54}$ enabling the centres to cater to the specific industrial character of the neighbourhoods. Furthermore, the town centre similarly to Stevenage incorporated a pedestrian precinct, civic, cultural and community, entertainment and shopping, as well a market square and many courtyards; later expanded in 1974 to meet the needs of populace.

Swedish new towns were distinctive in comparison to other European models in their form and proximity to the city centre. The Swedish suburbs prior to Vallingby from the 30 s and

\footnotetext{
${ }^{52}$ Frederic J. Osborn and Arnold Whittick. New Towns: Their Origins, Achievements and Progress. London: 53 IBID, 128. Leonard Hill, 1977: 119.

54 IBID, 167.
} 
40s were dormitory suburbs where residents commuted to work in Stockholm; this was undesirable to planners influenced by satellite new towns from Great Britain. Rather than being within its own municipal jurisdictions, the new towns surrounding Stockholm lay within city boundaries forming satellite communities from which people commuted to work. Part of its success was through the planning of the region, as well as government support and leadership for a holistic sustainable model of efficiency. Sven Markelius was the Swedish architect and planner of Vallingby in the 1950s; his interest was in the decentralization of jobs and sought to change suburban districts into balanced, self-contained communities that were urban in character. ${ }^{55}$ In 1952, the general plan for Vallingby stated, "the changes in Greater Stockholm's structure are primarily dependent on the build-up of the communications [transportation] system." ${ }^{56}$

Vallingby, Sweden was an example of a transit oriented development TOD (TOD explained in subsection entitled New Visions). The creation of the subway system led to masses of people living within walking distance from subway stops, thus decreasing the need for automobiles. ${ }^{57}$ Extensive centres or centrums - a term used by the Swedes to designate the combined commercial, social, and cultural centres, encased each subway stop. The centrum at Vallingby was a large, pedestrian shopping mall, not just a retail venture, but also included a modernistic church, office buildings, and community and youth centres. In Vallingby, all paths led to centrums representing attempts by planners to bring a physical and functional focus to clusters of about 10,000 people. ${ }^{58}$ The Vallingby site plan consisted of six super-blocks or city districts that lined-up like beads on a string, each super-block was slightly off the side of the subway that focuses on the commercial and cultural centre or centrum. Greenbelts that contain principle arteries for transportation, and interior districts that were mainly pedestrian traffic separated Super-blocks. ${ }^{59}$

One of the major ideas behind the development of Vallingby was that high-density living was necessary for residential services to be provided with greater efficiency, and with higher accessibility. Attached to the centrum on the periphery were high-rise apartment buildings that overlook the urban scene. Intensive development of public services and facilities compensated for the lack of private space and private facilities within Vallingby. There was a major attempt to distribute the facilities used on a regular basis such as libraries, schools, retail services, and

\footnotetext{
${ }^{55}$ David Popenoe. The Suburban Environment: Sweden and the United States. Chicago: University of ${ }^{56} \mathrm{IBID}, 43$. Chicago, 1977: 47.

${ }^{57} \mathrm{IBID}, 44$.

${ }^{58}$ IBID, 60 .

${ }^{59}$ IBID. 167.
} 
day-care centres according to 'neighbourhood principles'. Furthermore, there is a direct relationship between the distance to a service and the amount it is used. The closer one lives to a service the more it will be used; this is true for free-time services like libraries, youth centres, recreational facilities, but also true for medical care and social welfare. At a distance of over 500-600 yards (about 460-550 metres), the use of many services drops off, this is especially true for young people and for working class households. ${ }^{60}$ The centrum also includes a post office, banks, liquor store and a variety of social, cultural, and governmental services.

Vallingby shows that urban dwellers could live comfortably in apartments if provided with an abundance of urban services to offset the limited private space. Vallingby also connected to both the city and countryside. The environment created at Vallingby was that of an active medium-sized town where all aspects of life take place. Its scale and density give ease of movement for both pedestrians and bicycling. Moreover, it provides a space that give youth a sense of completeness and the highest chance for community participation. The residential variety promoted environments that offer diversity of housing types, array of services, and a range of environments that could bring people together from many lifestyles. Finally, the impact of the holistic method of development preserved central metropolitan areas while at the same time created peripheral moderately high-density urban development that was just as desirable as city centres.

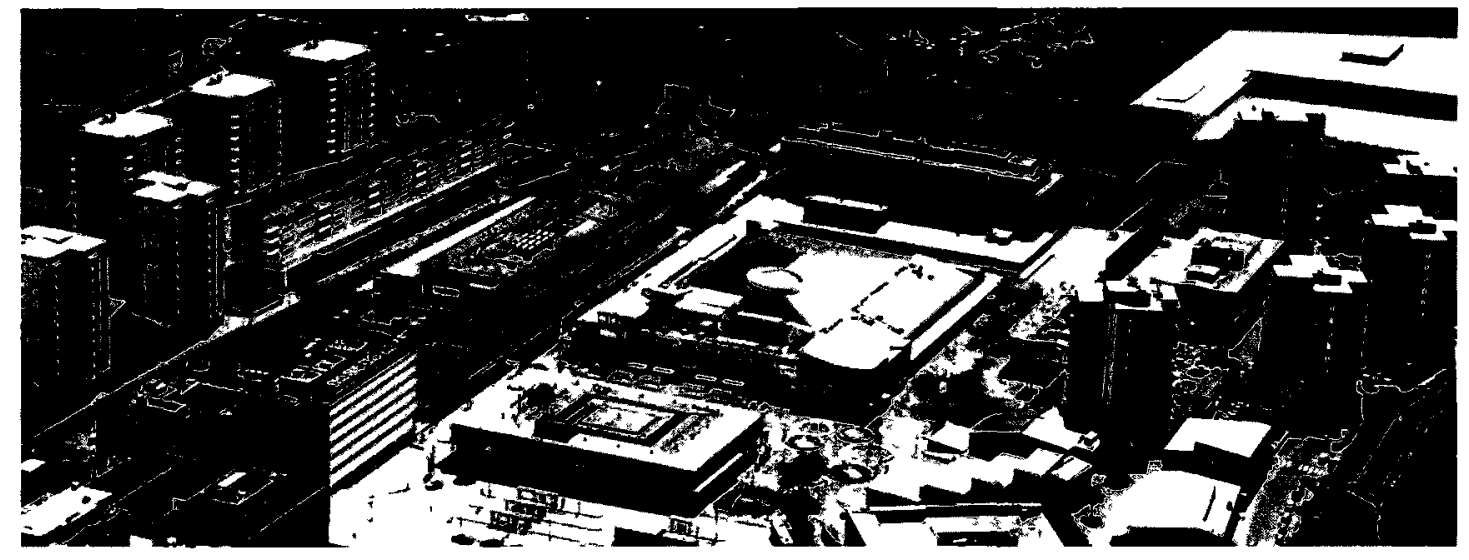

Figure 3: View of Vallingby

Over a decade after the New Towns appeared in Britain and the rest of Europe did the planning movement begin to influence the development in North America. Incorporated were elements from New Towns and the work of Ebenezer Howard. However, the translation of a

\footnotetext{
${ }^{80}$ David Popenoe. The Suburban Environment: Sweden and the United States. Chicago: University of Chicago, 1977: 70 .
} 
Garden City and New Town in North America was unique in form because it dealt with a different culture and fabric. In North America, planners embraced the automobile usage and created automobile-oriented new towns. For both the creation of Reston and Columbia discussed below planners and architects selectively drew from modernist new town planning and architectural styles, and frequently visited the new towns in Europe before and during work on their own plans.

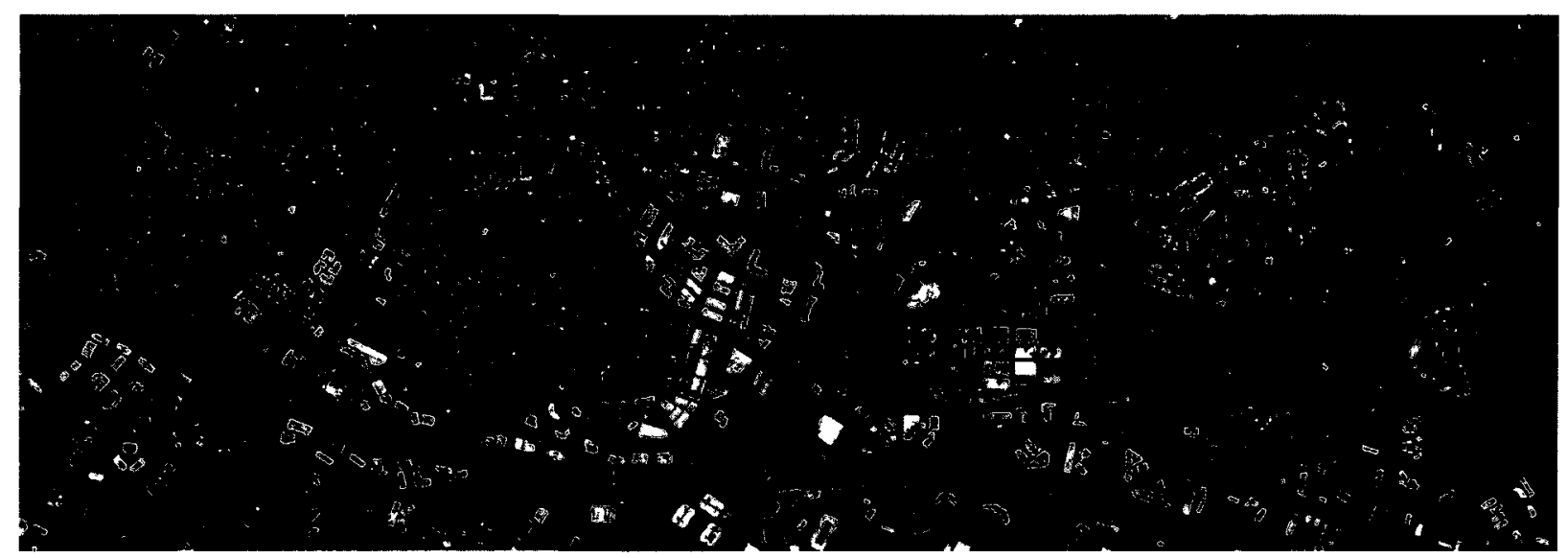

Figure 4: Reston, Virginia PA Satellite Image

Reston was as an alternative to both cities and conventional subdivisions. Robert Simon purchased 6,800 acres of land in rural Fairfax County, Virginia located at the outer edge of Washington D.C. suburbs in $1961 .^{61}$ It was master planned in 1962, as a new concept for suburbia with high-density corridors of apartments and townhouses rather than single-family homes that gave definition to the landscape. The planners' goal was to establish a balance of industry, residence, and commerce that reflected their influence from European New Towns. Reston created both village centres and a central town centre (discussed in a later section) at a high-density with cultural and commercial resources. The developer and planner of Reston envisioned the area as an adult-oriented suburban city housing nearly 75,000 residents. ${ }^{62}$ Simon and his team sought after creating an urbanized suburb. There was a mix of building types in high-density corridors, which gave Reston many qualities of a healthy city including architectural variety, park space, and a mixed range of people in different age and income groups.

Simon believed that a leisure society had already arrived for most Americans, and went on to say "that in the age of leisure people should have a wide choice of things to do that are

\footnotetext{
${ }^{61}$ Nicholas D. Bloom. Surburban Alchemy. Columbus: Ohio State UP, 2001: 18.

62 IBID, 18.
} 
stimulating, pleasurable, exciting, fun." ${ }^{63}$ Planners promised a total of seven villages, each with 10,000 to 12,000 people, featuring village centres - including shopping, cultural, and recreational facilities, a series of connected grade separated pedestrian walkways, districts of routes, a series of man-made and natural lakes, golf courses, recreation areas, numerous neighbourhood pools, tennis courts and play areas. ${ }^{64}$ Similar to Harlow there was an attempt to give an identity to each neighbourhood cluster; in the case of Reston, they were associated to specific leisure activities. For example, Lake Anne was a fishing and sailing village that incorporated a large dock and an artificial lake surrounded by residences. The Lake Anne village centre also included an apartment tower, and townhouses set above a retail plaza creating a sense of place and a feeling of inhabitation. The network of self-sustaining village nodes combined with the urbanized suburban form of Reston created a socially, physically, and visually diverse place.

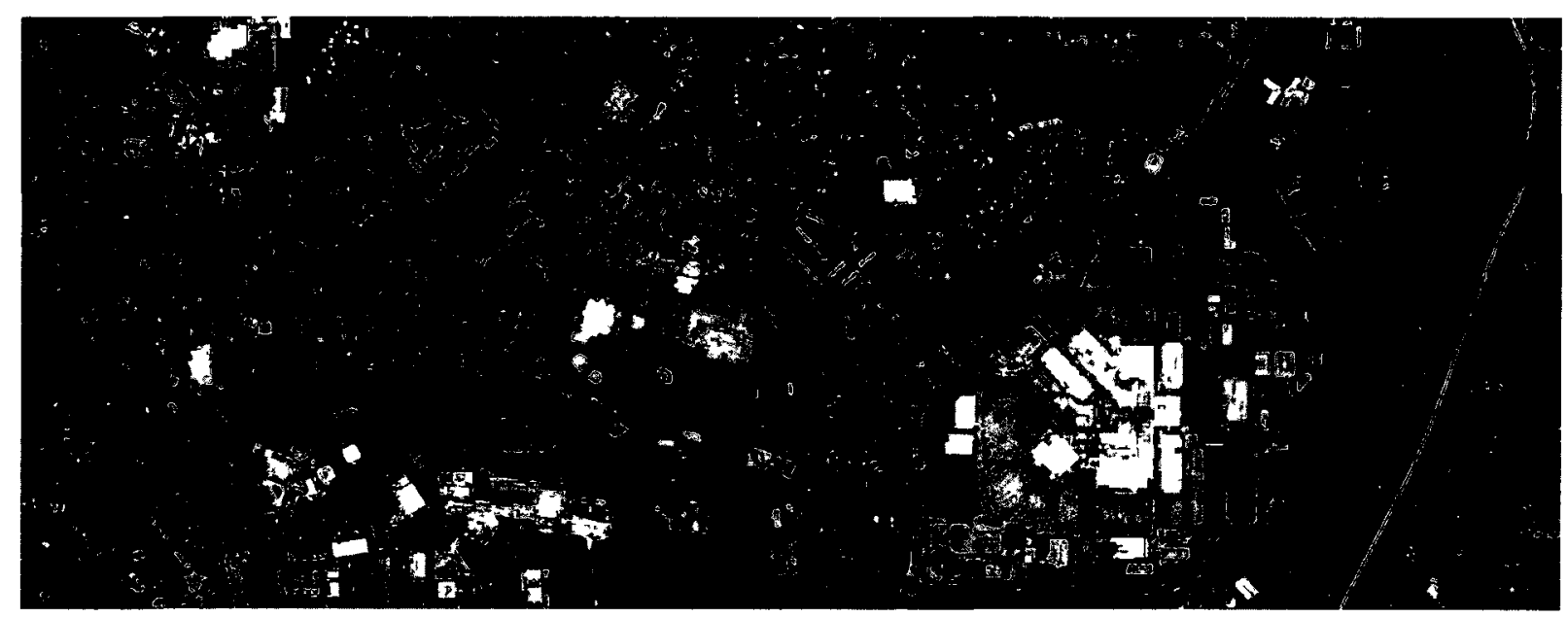

Figure 5: Columbia, Maryland Satellite Image

Columbia, Maryland established in 1963 was located only an hours' drive from Reston, in the rural Howard County. Columbia gained its fame by being a carefully planned, innovative suburban community. James Rouse assembled 14,000 acres by 1969 for his new community, with a vision of a series of intimate small towns; he believed the undertaking would bring him both profit and research in community building. ${ }^{65}$ The target population was 100,000 residents divided into villages of about $12,000 .^{66}$ Each village was to have its own centre combining

\footnotetext{
${ }^{63}$ Nicholas D. Bloom. Surburban Alchemy. Columbus: Ohio State UP, 2001. 21.

64 IBID, 22.

${ }_{65}$ IBID, 36.

${ }^{66} \mathrm{IBID}, 33$.
} 
public space, stores, high school or middle school, community centre, churches and recreational facilities. Unlike Reston, Columbia was family-oriented focusing on elementary schools, smaller neighbourhood stores and neighbourhood centre buildings. Morton Hoppenfeld who directed the planning and design, envisioned Columbia consisting of "alternative cultures and varied lifestyles brought together by a social and physical environment and enable to co-exist, overlap, thrive." 67

Planners hoped to create active public community spaces, a feature they felt was lacking from the suburban strip. Their plan of action was to place higher density housing near the village centres, and build a geographic middle for each village. The villages included a mixture of single-family homes, apartment complexes, and townhouses arranged in smaller scale neighbourhoods that included community facilities, small stores and pools linked by parkways. Similarly to Reston, Columbia also incorporated into the planning a town centre which is discussed in a later subsection.

\section{SUMMARY}

In summation, this section shows the influence of Ebenezer Howard's theories of satellite towns/garden cities on the development of the suburbs over time. Their translation, and success truly depended on how well integrated all aspects of life are within the fabric - the creation of whole communities. The proximity of the services and public spaces also play a role in the developments success, as does the ability for inhabitants to connect and access public transportation. The creation of village centres or nodal development can be the key to repurposing suburbia.

\section{NEIGHBOURHOOD MODEL}

Clarence Perry and Clarence Stein saw the scale of the neighbourhood as a means of creating complete communities. The ideas and theories mentioned above have played a role in the creation of the neighbourhood unit. Only by creating successful developments at the scale of the neighbourhood, can the parts in turn help create the whole.

Clarence Perry defined a neighbourhood in the modern era. He created a neighbourhood unit plan that adapted Ebenezer Howard's garden city to suit American issues within the city, and published in 1929 his developments in the Regional Plan of New York and Its Environs. The neighbourhood unit called for an ideal neighbourhood size to be 160 acres bounded by major streets, a mix of retail, office, civic and park uses, connected by a street

${ }^{67}$ Nicholas D. Bloom. Surburban A/chemy. Columbus: Ohio State UP, 2001: 41. 
network and a population large enough to support an elementary school. ${ }^{68} \mathrm{He}$ suggested that the centre of each neighbourhood is the local school and associated playground reachable on foot within a half mile. Surrounding the school were central community institutions. Local shops were located at the corners within a quartermile of the centre along arterial roads so that they can serve adjoining neighbourhoods. ${ }^{69}$ Thus, his plan provides limitations of size and appropriate densities.

Clarence Stein in the 1920s made serious attempts to define the urban form. He looked for the best way to

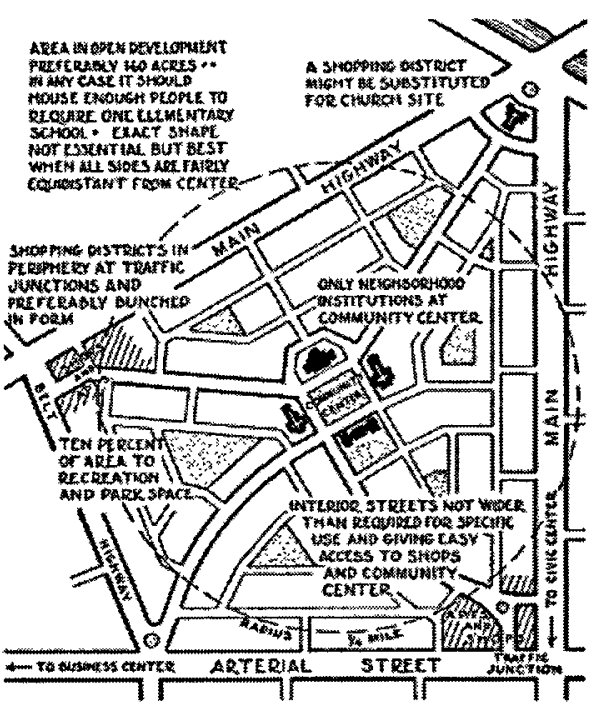

Figure 6: Neighbourhood Unit avoid the anonymous quality of the city, and strongly advocated the idea that the neighbourhood unit was the basic module of cities. Stein built off the thoughts and ideas of Clarence Perry at the time. Clarence Stein and Henry Wright implemented their ideas to design Radburn, New Jersey in $1928 .^{70}$ The most important innovation was the super-block, which replaced individual yards and alleys with landscaped common spaces behind houses - essentially separating pedestrians from automobile traffic. ${ }^{71}$ Moreover, Radburn introduced the creation of the cul-de-sac into suburban typology. In spite of all the innovations, the project failed during the depression.

\footnotetext{
${ }^{68}$ Douglas Farr. Sustainable Urbanism Urban Design With Nature. New York: Wiley, 2007: 42.

${ }^{69}$ Peter Geoffrey Hall. Cities of Tomorrow: an Intellectual History of Urban Planning and Design in the Twentieth Century. Oxford, UK: Blackwell, 2002: 126. 70 IBID, 110.

71 IBID, 127.
} 


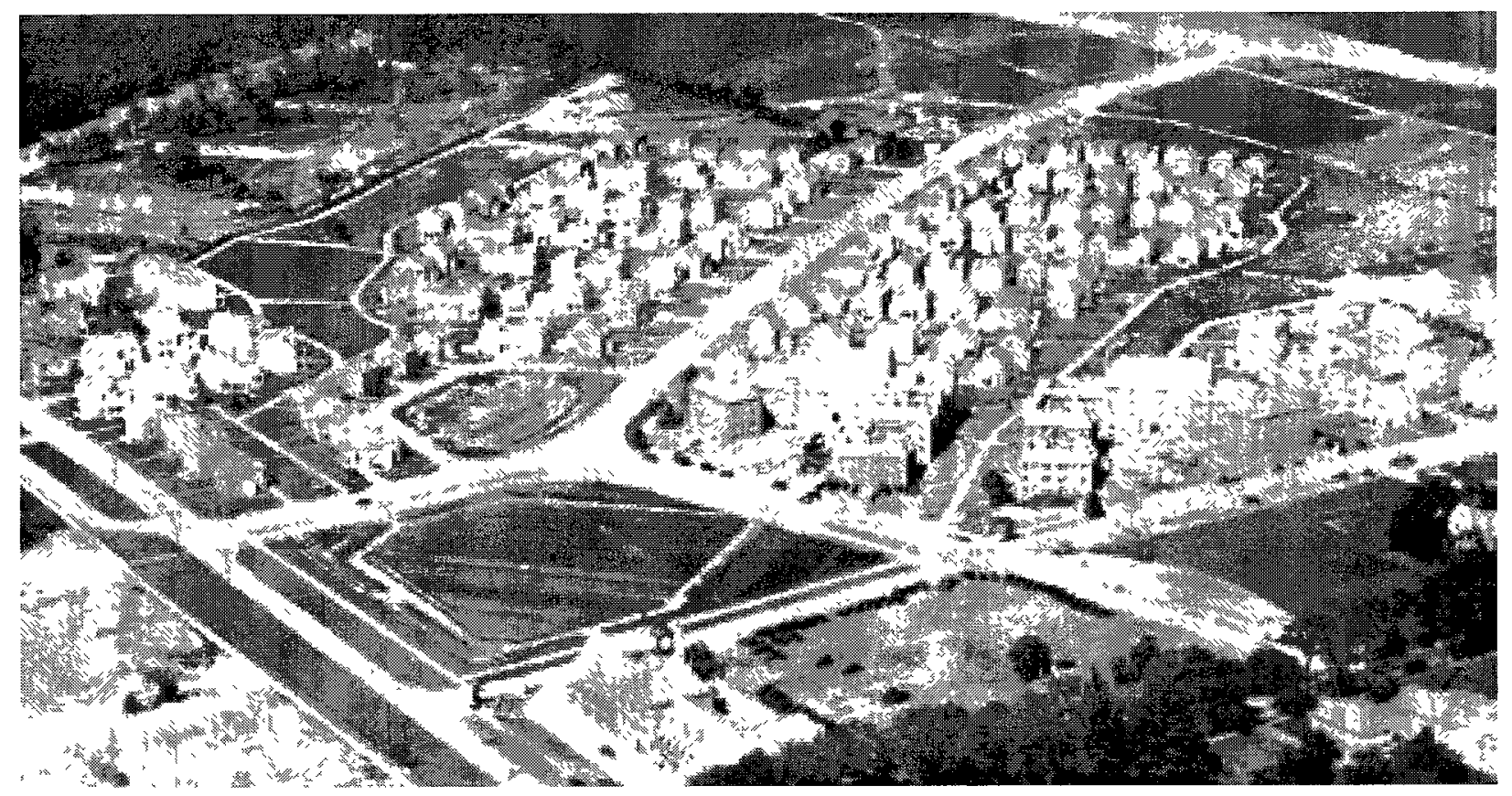

Figure 7: Radburn, New Jersey

Influenced by Clarence Perry and Clarence Stein's thoughts about the neighbourhood makeup, Don Mills was constructed in Toronto in the 1950s. Additionally, Don Mills was a loose interpretation of a New Town, a concept that gained prevalence since the $20^{\text {th }}$ century, and was one of the first projects to build on New Town principles in North America. E.P Taylor's Don Mills, was the most influential development in Canada during the $20^{\text {th }}$ century. ${ }^{72}$ The creation of Don Mills was the beginning of experimentation and development on greenfield sites. Don Mills is composed of 2,063 acres of land, for a population of 29,000 residents. Macklin Hancock was the chief planner who designed Don Mills. Hancock's plan had five concepts: neighbourhoods, discontinuous road system, abundance of green space, new house forms and lot configurations, and a separation of uses and activities. Land was divided into four by the intersection of Lawrence Avenue and Don Mills Road where each quadrant was treated as a separate neighbourhood. Hancock very much believed in the importance of the neighbourhood as an ordering force in contemporary society. He wrote:

"The neighbourhood unit in each case is composed of all the elements which go toward making the elementary school the cultural focus.... the residential street system focusing toward the school with its related playground and

\footnotetext{
72 John Sewell. The Shape of the City: Toronto Struggles with Modern Planning. Toronto: University of Toronto, 1993: 80 .
} 
open space. Residents will then be conscious of their neighbourhood identity in the overall scheme of the town."

Hancock's community was a mixture of residential forms composed of apartments, singles, semi-detached, and row houses. ${ }^{74}$ He wanted a mix of incomes and planned a mix of both ownership and rental property. The semi-detached units were for renting, using government subsidies to ensure the community had a fair share of low-income tenants. His plan also included non-residential uses such as commercial (discussed in a later section), institutional, and industrial; mimicking a complete and self-sufficient community. Unlike traditional city design, the uses including types of residences were separated from each other. Each block contained only one type of residential use.

Taylor's success encouraged others to follow his model community. Soon all development proposals in Toronto and across the country were based on Macklin Hancock's radical proposal: the looping discontinuous street system

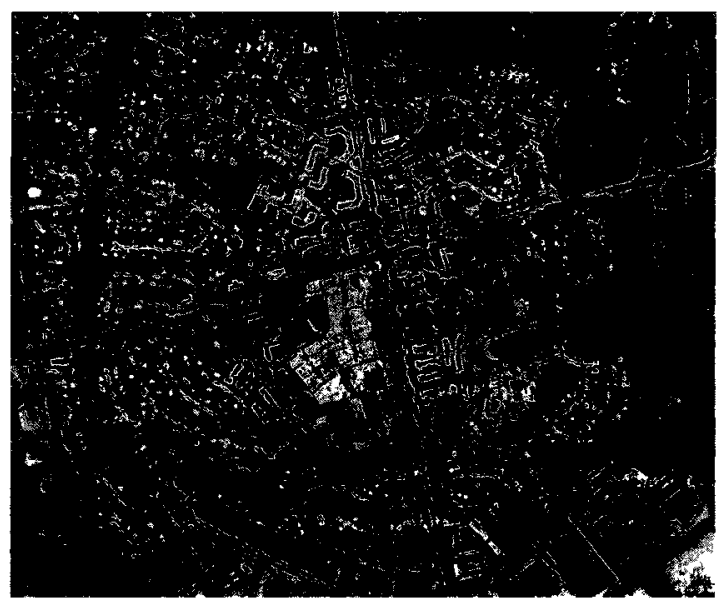

Figure 8: Don Mills Satellite Image model, including neighbourhood quadrants, walkways, houses on large lots, walkup apartments, a central shopping mall, and industrial uses at the edge.

\section{SUMMARY}

The creation of the neighbourhood block and its various translations shows the importance of neighbourhood design for the formation of self-sustaining communities. Only by creating successful neighbourhoods in the appropriate scale and size does the neighbourhood begin to shape the city or suburb.

\section{HIGH-DENSITY AND HIGH-RISE LIVING}

Density refers to the population occupying a given area of land expressed by a count of dwellings, inhabitable rooms, or persons per hectare/acre $;^{75}$ it is also the measure of the amount

\footnotetext{
${ }^{73}$ Hancock and Lee 1954, 3.

74 John Sewell. The Shape of the City: Toronto Struggles with Modern Planning. Toronto: University of Toronto, 1993: pg. 9.

75 Javier Mozas. Densidad; Density : Nueva Vivienda Colectiva : New Collective Housing. Vitoria-Gasteiz:
} 
of activity found in an area. High-density optimizes land-use, lessons pressures on agricultural land, promotes walkability, reduces risk of traffic accidents, allows for more profitable public transit, and creates areas of urban activity that favours trading and cultural exchange. ${ }^{76}$ Much higher densities are possible without undermining the quality of life. Design and layout of urban areas will determine their ability to accommodate a higher density of population. This section looks at the theories and concepts of Le Corbusier, who in the $20^{\text {th }}$ century devised a solution for overcrowded cities by creating skyscrapers of living and working that opened up the ground plane. The following examples show how high-density and high-rise living have been a vision of efficiency, and later helped to shape cities around the world.

Driven by the vision of order and efficiency, Le Corbusier developed plans for the "Contemporary City for 3 Million Inhabitants" in 1922. The "Contemporary City" was to be the counterpoint to industrialized Paris. The Paris Le Corbusier first encountered was suffering of problems caused by incompatibility of modern industry with a pre-modern urban infrastructure in 1916. He feared for the health of cities, and the fate of urbanity, and concluded, "that the machine, if properly used, could create a society of order, abundance, harmony, and beauty." 77 Le Corbusier emphasized the importance of building at high densities in city centres, and allowing the maximum space possible for greenery and transportation routes with design elements such as roof gardens, and streets on pilotis. ${ }^{78}$ His way to address the problem of the city - overcrowding, congestion, lack of air, light and recreation space, was to build vertically. The centrepiece of the "Contemporary City" was a group of 24 cruciform skyscrapers intended to be office buildings set within a large, rectangular park-like green space. At the centre was a huge transportation hub that segregated pedestrian circulation paths from roadways for automobile use. Outside the central business zone was the residential area that had two types. Luxury apartments were part of the middle-class environment that incorporated entertainment and cultural complexes to meet their needs. Le Corbusier also provided modest accommodation for the blue-collar workers and clerks in a separated satellite area around courtyards, providing them with garden apartments with green space, sports facilities and entertainment. ${ }^{79}$ Unlike Paris, the "Contemporary City" would be completely class-segregated.

A+t Ediciones, 200614

${ }^{76}$ Javier Mozas Densidad, Density Nueva Vivienda Colectiva - New Collective Housing Vitoria-Gasteiz A+t Ediciones, 200643

${ }^{77}$ Fishman, Robert Urban Utopias in the Twentreth Century: Ebenezer Howard, Frank Lloyd Wright, and Le Corbusier New York Basıc, 1977183

${ }^{78}$ Mumford, Erıc Paul The CIAM Discourse on Urbanism 1928 - 1960 Cambridge, Mass u a : MIT, 200015.

${ }^{79}$ Hall, Peter Geoffrey Citıes of Tomorrow an Intellectual History of Urban Planning and Design in the 
The image was a city of skyscrapers, of modernity creating a better society and conditions for all; cultivating into a new urban utopia.

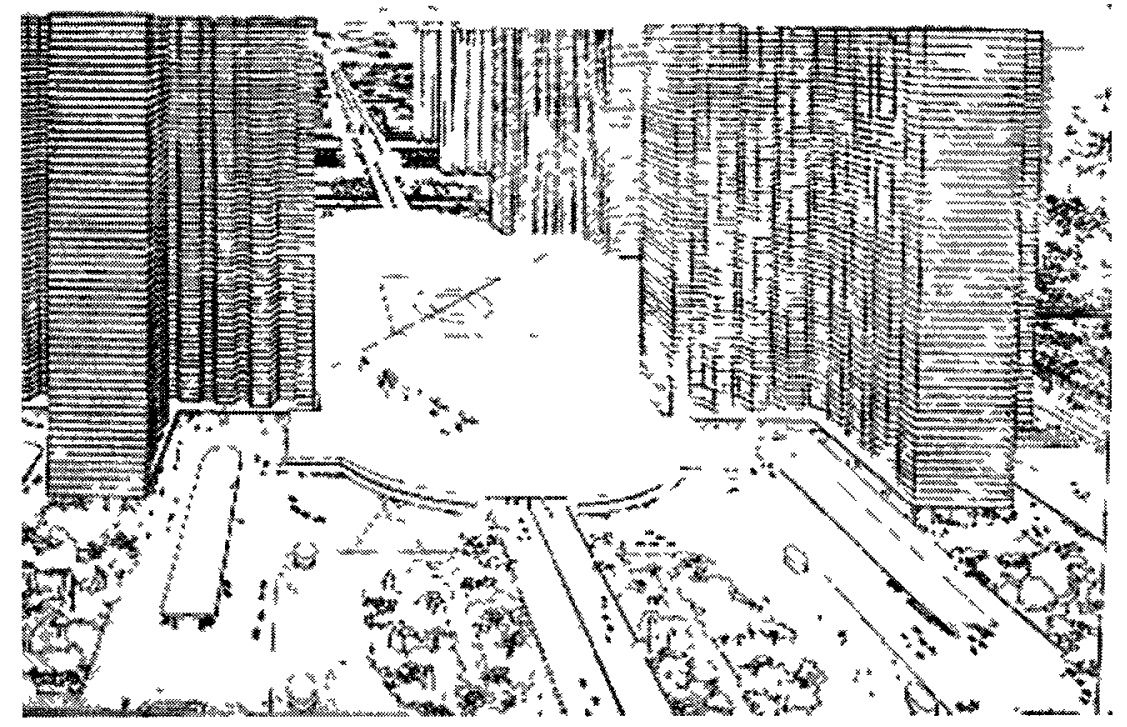

Figure 9: Contemporary City for 3 Million Inhabitants

Le Corbusier expanded and reformulated his ideas on urbanism when he published $\mathrm{La}$ Ville Radieuse (The Radiant City) in 1935. The most significant difference between the Radiant City and the Contemporary City is that the Radiant City abandons the class-based segregation. Instead, housing was assigned according to family size. He resolved the conflict between density and open space. Radiant City also marked Le Corbusier's increasing dissatisfaction with capitalism, and came to believe in the virtue of centralized planning which would cover not only city building but also all aspects of life. ${ }^{80}$ Like Le Corbusier, Robert Moses, a "master builder" and one of the great urban planners of America of the mid- $20^{\text {th }}$ century, believed that the city could save itself by increased density. The goal was to lure the middle-class back to the city, replacing the slums with high-rise residential buildings set in open green landscapes.

\section{SUMMARY}

Le Corbusier's theories to solving city and urban problems were to create skyscrapers that increase density and open up the ground plane. His ideas influenced city and suburban development to this day. Chapter 4 explains how the notion of towers has influenced suburban development as a means of increasing density and living compactly in Toronto. Le Corbusier

Twentieth Century Oxford, UK Blackwell, 2002210

${ }^{80}$ Hall, Peter Geoffrey Cities of Tomorrow: an Intellectual History of Urban Planning and Design in the

Twentieth Century Oxford, UK Blackwell, 2002210 
has thus far been the only theorist who has seen the solution of urban issues from within through retrofitting. High-density and verticality are important characteristics that should be implemented in future suburban repurposing, and can positively impact the landscape, the inhabitants, and the efficiency of the system as a whole if correctly executed.

\section{SHOPPING MALLS AND THIRD PLACE}

The term town centre and shopping centre in the present are interchangeably used. A town centre however, differs from a village centre (discussed in the previous section). Village centres are the creation of nodal neighbourhoods, each incorporating community and civic facilities, public domain, as well as amenities for the localized populace within walking distance. Typically, village centres are linked together to form the town; a larger town centre acts as the central space for the larger district. Since World War II, suburbs in North America have not produced village centres, but rather town centres/shopping malls with smaller strip plazas dispersed at the scale of the automobile. This section looks at the meaning and theory behind shopping centres, as well as how they have contributed to shaping the post war suburbs. The examples illustrated are attempts to create vital community spaces. Additionally, Ray Oldenburg's third place theory explained in this section as a means of comparison and contrast to see the correlation and importance of third spaces in future development. By understanding the similarities and differences between different projects helps to understand and incorporate positive characteristics and concepts into future projects.

Shopping centres since the 1920 s referred to any dense trade area, whether located in a downtown, a city neighbourhood, or a suburb. ${ }^{81}$ Victor Gruen believed that there needed to be a mixing of retail, restaurants, recreational and community establishments that were profitable so that the shopping centre would serve as "the centre of cultural activities and recreation." ${ }^{182}$ He believed that communal functions were crucial to the shopping centres role in postwar cities and believed that shopping malls would be an "important meeting place of the community" like "the market place or Main Square of older cities." 83 Frank Lloyd Wright said after visiting Gruen's project Southdale mall:

"What is this, a railroad station or a bus station? ...In all this there should be increased freedom and graciousness. It is wholly lacking.... Who wants to sit in

\footnotetext{
${ }^{81}$ M. Jeffrey Hardwick, and Victor Gruen. Mall Maker: Victor Gruen, Architect of an American Dream. Philadelphia: University of Pennsylvania, 2004: 79.

82 IBID, 80.

${ }^{83}$ IBID, 80.
} 
that desolate looking spot? You've got a garden court that has all the evils of the village street and none of the charm."

Wright hated Gruen's design and thought his inspiration was misguided. Gruen consciously tried re-creating an aura of urbanity for suburbanites. He planned Southdale to halt sprawl and perceived it as a social and commercial centre, a "blight-proof neighbourhood," ${ }^{84}$ however, his plan failed and sprawl surrounded the mall.

The "primary human instinct is to mingle with other human beings," ${ }^{85}$ said Victor Gruen. He thought that shopping centres might "well be regarded as satellite downtown areas, offering much of what the metropolitan centres give." ${ }^{86}$ The shopping centre in the 1950s came to define the American suburban landscape and played a critical role in the development of the contemporary regional city. What distinguished a shopping centre from other retall arrangements was that a single owner controlled it. The ability of public spaces to support the social and cultural activities would ensure the commercial success of the centre. Gruen Identified the core issue of shopping centre design as a formal equation between access, parking, the mix of social, cultural, and commercial functions, the public spaces in which the shopper could promenade, window shop, consider, and then buy. ${ }^{87}$ "The shopping center of tomorrow will be more than its name implies... [It] will, besides its commercial function, fill the vacuum created by the absence of social, cultural and civic crystallization points in our vast suburban areas." 88 Judith Coady studied shopping malls for five years explains her findings to the New York Times as follows:

"I expected to find the mall as some kind of new community, particularly for suburbia... But I found that the mall is not a community at all... There was the appearance of community, but the interaction was truncated if there was any at all. The focus is on consumption... The issues that are part of our everyday community are not discussed there, so it doesn't function as a community."

As discussed in the earlier section, Reston was the creation of a North American New Town. Robert Simon, the creator of Reston, was pushed out of control of its development soon after the creation of Lake Anne village centre. Simon's plans of Reston designated an area for the creation of Reston Town Centre, but believed early on that construction be delayed to not

\footnotetext{
${ }^{84} \mathrm{M}$ Jeffrey Hardwick, and Victor Gruen Mall Maker Victor Gruen, Architect of an American Dream Philadelphia University of Pennsylvanıa, 2004154

${ }^{85}$ Wall, Alex Victor Gruen from Urban Shop to New City Barcelona Actar, 200556

${ }^{86}$ IBID, 56

${ }^{87}$ IBID, 81

${ }^{88}$ IBID, 80

${ }^{89}$ Philıp Langdon A Better Place to Live Reshaping the American Suburb Amherst University of Massachusetts, 199421
} 
interfere with the development of the village centres. In the 1980s, when the new developers of Reston began to plan the suburban town centre, and submitted the design to the Urban Land Institute for criticism, experts told them that their plan failed to reflect the vision of Reston and that the design should be "more urban and less suburban, and also more cultural." As a result, the project staff began to integrate taller office buildings, brought in a mixed-use development team and expanded the retail plans. Kenneth Wong, lead developer believed that the town centre would serve as a public space: "We wanted to create a main street with a town square the way people used to do it." a large neoclassical plaza, a seasonal ice-skating rink, and a movie complex. The elements are sited in a grid that is surrounded by parking lots hidden from the interior of the complex.
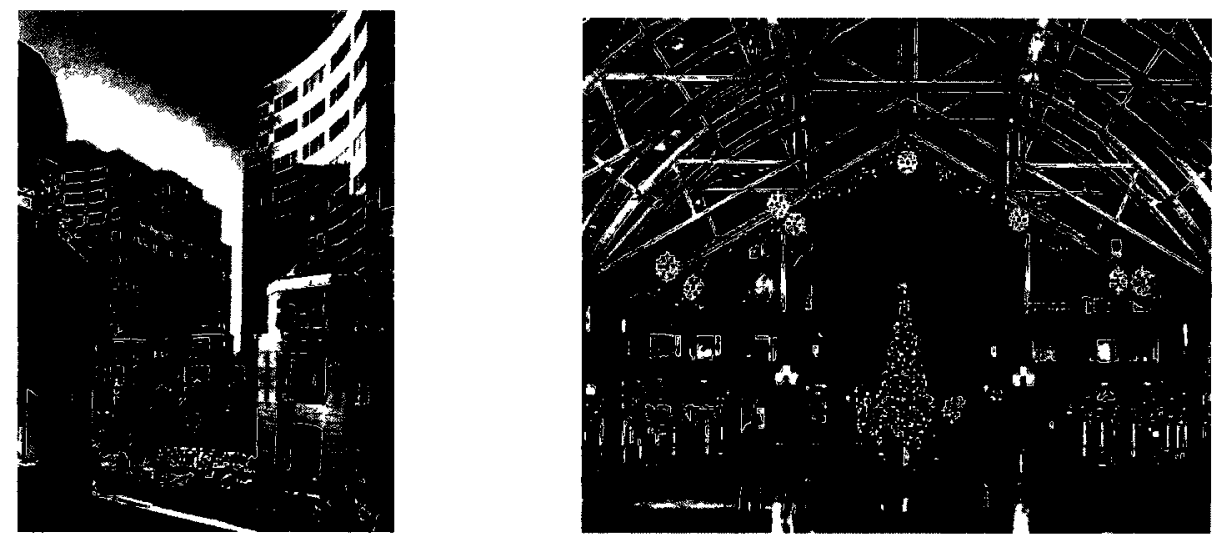

Figure 10: Reston Town Centre

After its construction, Robert Simon said that he liked the place and that "this is not a mall, this is an urban phenomenon - a place for shopping and socializing." 92 The town centre had the illusion of urbanity. Simon predicted in the 1960s that the future town centre would "be more like an urban centre without cars, because the cars will be underneath it or in several parking fields removed from it." 93

\footnotetext{
${ }^{90}$ Nicholas D. Bloom. Surburban Alchemy. Columbus: Ohio State UP, 2001: 29.

91 IBID, 29.

92 IBID, 29.

${ }^{93} \mathrm{IBID}, 28$.
} 

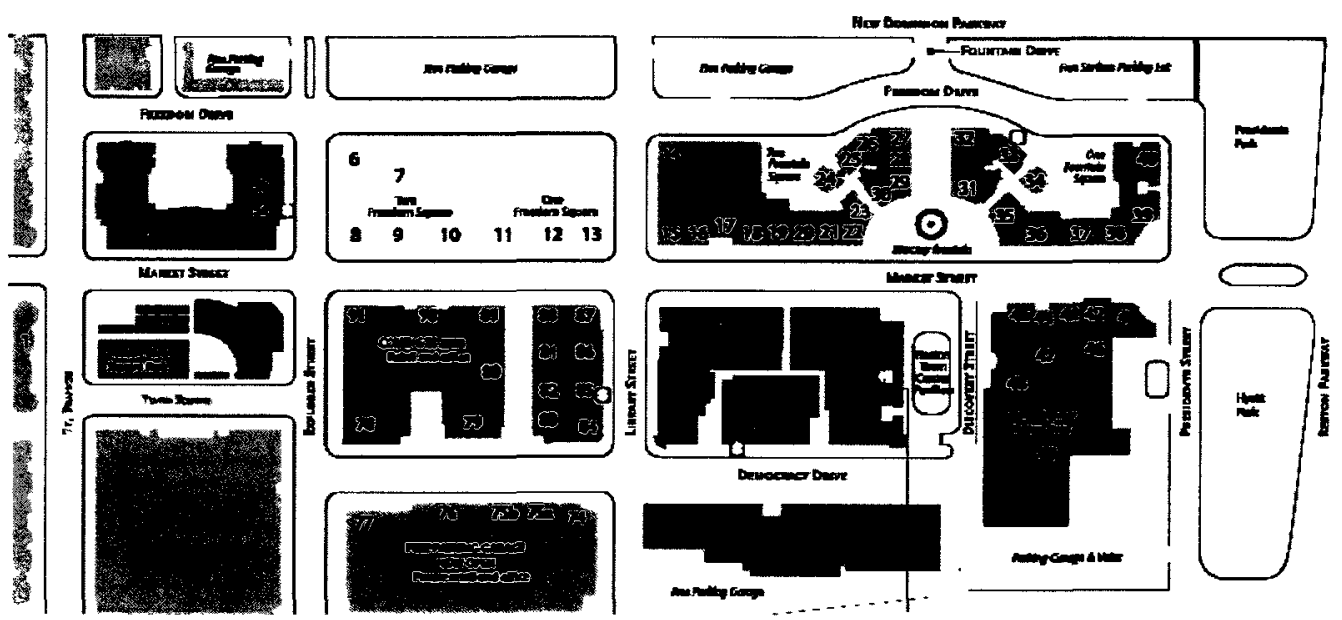

Figure 11: Reston Town Centre Site Plan

Columbia's town centre differed from Reston's town centre in form. Columbia's town centre took the shape of a covered shopping mall following the American trend to internalize the public spaces within communities. Rouse believed that the mall could function as both a regional shopping destination, as well as an enclosed town centre, and help create community in suburbia. The shopping centre incorporated many features associated with a traditional main street to bring a level of urbanity such as trees, fountains, large clock and garden spaces. When the mall first opened in 1971 it was positively received, however the dominance of the mall was the reason for the failure of urbanity at its downtown. ${ }^{94}$ Unlike Simon at Reston, Rouse made the decision to develop the town centre relatively early on in the build-out of Columbia, and as a result Reston's town centre has taken on a form that is more versatile and of continued relevance into the future because of its dense, multi-use pedestrian-friendly design.

Similar to Reston and Columbia, Don Mills also incorporated a commercial area within its plan. Don Mills as discussed above was a self-contained neighbourhood with various housing types, industry and community uses such as shopping, recreation, and schools. The original mall, opened in the 1950s was outdoors and had covered walkways. A renovation in the 1970s expanded and enclosed the mall, and helped it serve as a natural meeting space and community hub for the neighbourhood. The new commercial property developed by Cadillac Fairview called Shops at Don Mills, a 'lifestyle centre,' replaced an earlier mall demolished despite local opposition in 2006.

${ }^{84}$ Nicholas D. Bloom. Suburban Alchemy. Columbus: Ohio State UP, 2001: 51-52. 

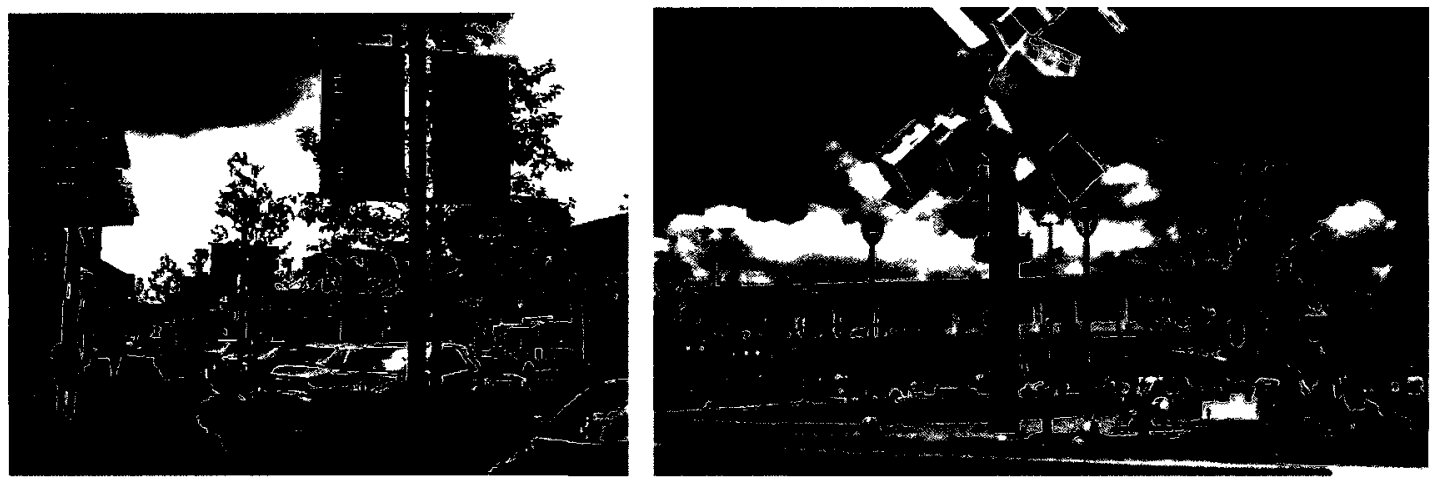

Figure 12: Views of Shops at Don Mills

The new 'lifestyle centre' brings the stores back outside facing private lanes with parallel parking almost like a neighbourhood retail strip. It includes bike racks, benches and speakers playing background music. Unlike the neighbourhood-oriented stores in the previous mall, the new stores are high-end. The internal road networks, street furniture, and a mix of facades give the illusion of a shopping neighbourhood; however, it is a managed, private space, with Cadillac Fairview security guard patrol. Surface parking is located at the edge Don Mills Road. In the middle of the complex is a central square encompassed by art, fountains and a planned winter skating rink replicating public uses found in a downtown. The centre is not finished; there are plans for a mid-rise condominium development that would be facing the proposed Don Mills LRT line. The owners realizing that the previous mall was underutilized - a dying mall of greyfield status revitalized the site before it created a gaping hole in the city fabric.

In the book entitled The Great Good Place, sociologist Ray Oldenburg argues that people need a third place outside of work and home where they can make contact with others. For centuries, society has generated informal gathering places where the stresses of work and home can be left behind for awhile, this is denied in most suburbs built in the past 60 years. Residential subdivisions zone out the tavern, café, coffee shop, butcher, hairdresser, community centre, bar, neighbourhood store, and other gathering places. Richard Sennett observes that unlike European middle-class counterparts such as the French or German, North American culture lacks the daily visits to sidewalk cafes or pubs. Hence, there is a lack of the third realm of satisfaction and social cohesion beyond the realms of home and work, which is an essential piece of a good life.

The pleasures of the North American landscape have been reduced to consumerism. The third place used to signify "the core settings of informal public life." The first place is the home - the most important place, the second place is work. The prominence of third places 
varies with cultural settings, in ancient societies the third place was actually primary, being of the greatest structures in the village and commanding the most central locations. In both Greek and Roman societies, their values dictated that the agora and the forum should be great, central institutions; that homes should be simple and modest, and that the architecture of cities should affirm the worth of public and civic individuals over the private and domestic one. ${ }^{95}$ However, in modern times third places survive without the importance and elegance of previous centuries.

The suburbs, Robert Goldston describes "offers almost no facilities for accidental encounters or for collective meetings; social participation beyond the narrow range of family and friends is limited to the passive receipt of goods, information, and entertainment from impersonal and isolated sources." The level of activity on a Main Street for example is because a great majority of individuals who visit these places did so with the desire of company. During the prewar period, the small town Main Street was where people would gather and go; people later claimed that the Main Street was reborn in the form of a shopping mall as the core of community belonging in America. However, the shopping mall as mentioned in this section fails to actually offer and replace the qualities that people loved, and that worked in a Main Street. Where once there were places, there are now non-places. In a real place, the human being is a person, and in non-places individuality disappears, one is only the customer or shopper, client, patient or car parked. Ray Oldenburg explains: "The third place does belong to the past in the sense that most of them are to be found "in the debris" of a previous order... we don't want the past. We can't have the past. We don't need the past. We need the places!"96

\section{SUMMARY}

Town centres and shopping centres attempt to emulate the urbanity and life of the Main Street while at the same time try to be a third place. In most cases, the mark was missed as demonstrated in this chapter. Reston Town Centre (RTC) is an impressive example. RTC was the closest in maintaining and attempting to create the allure of urbanity, and celebrated the qualities of Main Streets by building a well-rounded space for the community and the district. The positive aspects of town and shopping centres can be interpreted and incorporated for the creation of nodal development (similar to village centres) that act as a third place for the local community.

\footnotetext{
${ }^{95}$ Ray Oldenburg. The Great Good Place: Cafés, Coffee Shops, Community Centers, Beauty Parlors, General Stores, Bars, Hangouts, and How They Get You through the Day. New York: Paragon ${ }^{96}$ IBID, 209. House, 1989: 17.
} 


\section{NEW POST-MODERN VISIONS}

Past theories and models transform into new post-modern movements. The new movements discussed in this section bring past theories into relevance by combining and depicting characteristics under a new package and name.

As a reaction to previous models and theories in planning mentioned above, the movement known as New Urbanism emerged in the 1980s with the urban visions and theoretical models for the reconstruction of the "European" city proposed by Leon Krier, and the "pattern language" theories of Christopher Alexander. In 1993, the Congress for New Urbanism formed in Chicago. New Urbanism was a reaction to the modern suburban condition of singleuse sprawl, but also an attempt much like earlier models like Garden Cities and New Towns to achieve the "best possible human settlement."97 The movement shows that the relationship between architecture and public space can be "urban" regardless of the building height or mass. Some principles of New Urbanism greenfield design are: walkability, connectivity, mixed-use, mixed-housing, quality architecture and urban design, traditional neighbourhood structure, increased density, green transportation, sustainability, and quality of life - all within pedestrian pockets. New Urbanism is most effective if planned on all levels from a single building, to groups of buildings, urban block, neighbourhoods, and networks of neighbourhoods, towns, cities, and regions. ${ }^{98}$ However, New Urbanism does have obstacles to overcome such as restrictive zoning codes enforced by municipalities that do not allow new urbanist developments, but allow for sprawl.

SmartCode is a form-based code that incorporates Smart Growth and New Urbanist principles. It is based on the rural-to-urban transect rather than separated-use zoning, thus it integrates a full range of environmental techniques. Municipal planning departments and the local government can administer SmartCode. In most places, it is actually illegal to build in the traditional neighbourhood pattern described below, and for that reason, SmartCode deals with the intersection between law and design. ${ }^{99}$ SmartCoode coordinates transect-zones at all scales of planning from the region through the community scale, down to individual lot and buildings. New Urbanists believe that the distinctions and rules put in place by SmartCode does not limit choice but expand them, and can act as an antidote for the one-size-fits-all development common today. Once adopted, it allows urbanism to evolve and mature over time without losing the foundation of order thereby increasing in complexity, density and intensity.

\footnotetext{
${ }^{97}$ Emily Talen, New Urbanism and American Planning: The Conflict of Cultures. New York: Routledge, 2005: 5.

${ }^{98}$ Smart Growth Online. Web. Nov. 2009. <http://www.smartgrowth.org/>.

${ }^{99}$ SmartCode Version 9.2. Town Paper, 2009: V.
} 
The New Urbanism movement or traditional neighbourhood development (TND) is small in area to allow for walkability. An example of a traditional neighbourhood development is Seaside located in the Florida panhandle where development began in the 1980s. Seaside is a dense clustering of traditional-looking houses, with mandatory front porches located close to the street; healthy social interaction is supposed to follow automatically because of continuous and unavoidable contact between residents and onlookers. ${ }^{100}$ It is not a matter of whether the New Urbanist ideal of community characterized by visual charm, and formalized public interchange is bad; the issues are that supporters assume that good design in and of itself will automatically solve major metropolitan issues such as transportation, jobs, education, and personal safety. New Urbanism assembles much its rhetorical and political power through the nostalgic appeal to "community" as an answer for our social, economic and urban ills. Vincent Scully commented that Seaside, an icon of New Urbanism has "succeeded beyond any other work of architecture in our time... In creatıng an image of community, a symbol of human culture's places in nature's vastness."101 People make the presumption that "neighbourhood" and "community" have the same meaning and are what North Americans want and need. Community has always meant something different to different people. Community in New Urbanism is an attempt to transform large towns and cities, out of control places, into interlınked sites of "urban villages."

The most recent attempt at neighbourhood planning is LEED-ND (LEED for Neighbourhood Development) - a guide to assess sustainable community developments. The guide integrates the leading knowledge on urban design and smart growth, ${ }^{102}$ sustainable infrastructure and transportation, public health linked to built form, ecological site development, and green building into an inclusive system to guide and certify community developments. Eligible projects can be redevelopments, urban infill, and greenfield developments depending on the site. Size is the defining feature of a neighbourhood; it needs to be a comfortable distance for walking from the centre of the neighbourhood to the edge. Inspired by Clarence Perry's

\footnotetext{
100 Tom Martınson American Dreamscape. the Pursut of Happıness in Postwar Suburbıa New York Carroll \& Graf, 200041

${ }^{101}$ William S Saunders Sprawl and Suburbıa Mınneapolıs, MN Unıversity of Mınnesota, 200523

${ }^{102}$ Smart Growth coined by the Environmental Protection Agency to designate polıcies that help cities conform to environmental standards of clean air and clean water acts Smart growth recognizes the connections between development and the quality of life and leverages on new growth to improve on community Developments are town centred, transit and pedestrian oriented, mixed housing, commercial and retall uses, preserves open space, and thus it is the return of the "urban village" - a place that has daily essential needs in close proximıty Some of its basic princıples are to create a range of housıng choices, a walkable neighbourhood, encourage community and stakeholder collaboration, foster distinctive attractive communities with a strong sense of place, mixed land uses, preserves open space, farmland, natural beauty and critıcal environmental areas, provides transportatıon choices, and takes advantage of compact buildıng design It encourages regional-scale planning that identifies both natural areas to be preserved and growth areas targeted for higher density, transit-oriented development Smart growth lınks economıc development, land-use plannıng, and environmental protection
} 
ideas and models for neighbourhood planning, LEED-ND suggests a maximum of 320 acres to serve as a guide on the size reasonable for a neighbourhood, based on the distance a person would walk or take a bicycle. ${ }^{103}$ The guide emphasizes the creation of compact, walkable, vibrant mix-use neighbourhoods with good connections to nearby communities, and creating a pedestrian scale. The sustainable benefits increase when the neighbourhood developments are in close proximity to transit, and when residents and workers can travel safely by foot or bicycle to jobs, amenities, and services. The goal of the program is to create a neighbourhood with a high quality life and healthy inhabitants.

Although LEED-ND is relatively a new guide, it has received criticism. Kaid Benfield of the NRDC believes that if the point of LEED-ND is to provide a counter to sprawl than the program should not honour sprawl locations. ${ }^{104}$ Furthermore, because the guide is complex, it can also be expensive and time consuming with typical projects incurring $\$ 50,000-\$ 75,000$ in additional soft costs, analysis and documentation. ${ }^{105}$ Moreover, LEED-ND is not finished; it is in on-going progress and updated on a regular basis as it gathers feedback from experience. LEED-ND hopes to first rise to a zero-impact (net-zero) level of sustainability, and eventually reach a net-positive level.

Transit Oriented Development (TOD) is the philosophy that concentrates urban development around transit stations for the facilitation of increased accessibility. Its intentions are to provide alternatives to automobile-based land use, and to allow for human interaction in the public domain or 'urbanity' that is difficult to achieve in socially segregated car dependent environments. The goal is that centres (nodes) would link to transit. Furthermore, transit oriented development requires zoning that allows for a mix of uses to create dense centres with minimal parking and a proportion of affordable housing that can assist in their delivery. ${ }^{106}$ Public and private partnership and funding arrangements are inherently the most effective way to create TODs as opposed to state funding alone. The key is to focus new construction and redevelopment around transit nodes, thus TOD can be a tool to curb sprawl, and a method for retrofitting the suburbs opposed to new planned areas on greenfields. Multiple health benefits

\footnotetext{
${ }^{103}$ Congress for the New Urbanism, Natural Resources Defense Council, and U.S. Green Building Council. LEED 2009 for Neighborhood Development Rating System. Rep. Washington: U.S. Green Building Council, 2009. (pg. xviii)

${ }^{104}$ Kaid Benfield. "Switchboard, from NRDC :: Kaid Benfield's Blog :: The new LEED-ND standards: what's new, what's good, and what's not (part 3)." Switchboard, from NRDC :: Home. 9 May 2009. Web. 12 Dec. 2009. <http://switchboard.nrdc.org/blogs/kbenfield/the_new_leednd_standards_whats_2.htmi>. ${ }^{105}$ Laurence Aurbach. Introduction to LEED-ND for CNU Members. Rep. 30 June 2009. Web. 12 Dec. 2009. <http://www.cnudc.org/lmages/LEEDND_Intro.pdf>. (pg. 4)

${ }^{106}$ Carey Curtis, John L. Renne, and Luca Bertolini. Transit Oriented Development Making It Happen. Burlington, VT: Ashgate, 2009: 20.
} 
correlate to TOD. Residents of such neighbourhoods have higher rates of physical activity, lower body mass indexes, and reduced risk of respiratory ailments such as asthma. ${ }^{107}$ Those who live in less walkable neighbourhoods are more likely to be overweight or obese, and increase their likelihood of developing life-threatening illnesses.

Urban services and amenities are only viable if a minimum number of people are present. At least 86 people and jobs/acre of urban land are required before transit/walking/biking and short car trips can combine to reduce the need for driving. ${ }^{108}$ This kind of density is associated with a minimum range of urban services and amenities in a local centre. The above holds true if established within the limits of a $1 \mathrm{~km}$ radius. 10,000 people and jobs can create a local centre. Within a $3 \mathrm{~km}$ radius, a town centre is viable with around 100,000 people and jobs. ${ }^{109}$ In comparison, Vallingby centrums cluster populations of 10,000 people. Planners at Vallingby found the use of services drops off at around $460-500 \mathrm{~m}$, which is in line with Clarence Perry's radius of a $1 / 4$ mile $(400 \mathrm{~m})$ but about half that of the radius limits of TOD. Furthermore, Ebenezer Howard's Garden City, the pioneer of TOD, was designed for 30 people per acre; significantly less is the new towns of Reston and Columbia that are approximately 11 people per acre and 7 people per acre compared to what TOD has suggested above.

Trying to introduce transit-oriented development to outer suburbs is a challenge since the average suburban resident responds negatively to higher density urban living. Housing and jobs near transit will continue to appreciate in value because they create an overall more affordable lifestyle, as well as a better quality of life. However, TOD can offer a greater impact in the suburbs than in the urban core where the pattern of compact districts is already established. The annual report issued by Price Waterhouse Coopers and the Urban Land Institute gave their highest recommendation to markets that offered 24-hour cities, mixed-use places and access to transit.

The roots of transit-oriented development go as far back as Ebenezer Howards Garden City that linked to rail. New Towns also adopted the importance of connection and transit in the European examples above. The North American interpretations of a New Town were more suited for the automobile, and had transit that connected the different village centres together and to the central town centre. Transit-oriented development is no longer a new concept. Demographic and cultural trends more strongly than ever support public preferences for lively,

\footnotetext{
${ }^{107}$ Carey Curtis, John L. Renne, and Luca Bertolini. Transit Oriented Development Making It Happen. Burlington, VT: Ashgate, 2009: 156.

108 IBID, 15.

109 IBID, 15.
} 
unique destinations, and lifestyle choices. Transit Oriented Development positively responds to climate change, gaining infrastructure, healthy lifestyles, rising fuel costs, and housing affordability.

\section{SUMMARY}

As one can see the new visions of our time are very much building on the past. However, it is important to incorporate various initiatives together to create a truly holistic and better-built environment. Recently, the mentality of people has slowly begun to change. People are not only concerned about social issues as well as environmental and economical issues. Only when the three (social, environmental, and economic) are intertwined and approached together are we moving to the creation of something great. The urge for complete communities and neighbourhoods like fashion is coming back as environmental factors increasingly lead people to living in holistic localized communities that incorporate all aspects of life. 


\section{CONCLUSION}

The various examples in this chapter illustrate important points of departure and inspiration for the proposed design to follow. Now, building planned communities on greenfields needs to end, and instead the focus and attention for future developments should turn towards the repurposing of greyfield sites in the existing suburban landscape. By moving towards an urban, compact, transit connected nodal environment we are moving towards creating complete communities at the neighbourhood scale. By filling in or completing existing neighbourhoods, help construct a well-rounded and walkable environment. The design portion aims to build on this chapter by distilling key points and characteristics with the intention not to create completely new communities out on greenfields, but to "fix" the issues of the suburbs from within, on greyfields. 


\section{Toronto Morphology}

The immensity of Toronto's suburbs is often described as unintended sprawl; however, their shape conveys a different story. Toronto set itself apart from other cities by attempting to plan its future in the postwar era, and regional plans were drawn up in both 1943 and 1959. Eugene Faludi produced a Master Plan for the City of Toronto and Environs that was adopted in 1943. This plan did little to build on the city's strengths: its compact, mixed-use form, efficient transit and other services that supported civil society. Instead, his plan reflected the thinking at the time that privileged low densities to existing urban densities. Faludi set targets at 10,000 residents and/or jobs per square mile ${ }^{110}$ - half the density of the urbanized areas of Toronto at the time. Richard Harris describes the growth in that era by saying:

"People needed homes and wanted space; new transportation technologies brought cheaper suburban land within the reach of many; rising income made it feasible for governments to mandate (and enforce) building standards for health and safety. Land subdividers, developers, builders, and lenders were happy to oblige. What else is there to say? It is true that these trends were bound to shape the suburbs. It is also true that the suburbs were, and are, artificial constructions." 111

In 1954, Toronto created a metropolitan government, one of only two in North America (the other being New York). ${ }^{112}$ The responsibility of Metro Toronto was to administer the rapidly growing region, which was more rural than urban at the time. The aim was to fill inside its borders and to leave the land beyond as untouched.

The modern suburbs of Toronto contained extensive parks and protected natural systems, transit infrastructure, industrial zones, cultural and community facilities, universities, modern planned communities and numerous clusters of high-density, concrete high-rise apartment buildings. Toronto's growth was highly controlled by regional and modern planning, financed by the boom of the 60 s and 70 s, with the result that the form of Toronto's suburbs is unique in North America. ${ }^{113}$ Metro Toronto was privately developed and publicly directed,

\footnotetext{
${ }^{110}$ John Sewell. The Shape of the Suburbs: Understanding Toronto's Sprawl. Toronto: University of Toronto, 2009: 33.

${ }^{111}$ Richard Harris. Creeping Conformity: How Canada Became Suburban 1900-1960. Toronto: University of Toronto Press, 2004: 168.

112 Michael McClelland, and Graeme Stewart. Concrete Toronto: a Guidebook to Concrete Architecture from

${ }^{113}$ IBID, 212. the Fifties to the Seventies. Toronto: Coach House, 2007: 212.
} 
creating a metropolitan region organized into natural areas, employment, institutional, and residential zones. The image of 30 storey towers at the northern edge of Metro Toronto, 11 miles from downtown, triggered John Barber of The Globe and Mail to observe:

"Not since the first bird's eye views of the Italian Renaissance has a city looked so coherent: the densely human, heavily built-up urbe ending abruptly - and totally - at an ancient wall heavy with meaning, the Arcadian rus rolling unbroken to the horizon in striking contrast ...Although the wall surrounding 1960 s Toronto was made of policy, not stone, the meaning was still there. No other city in North America built high-density suburbs like these during the long postwar boom. Few modern cities in the world, if any, were better planned than Metropolitan Toronto."114

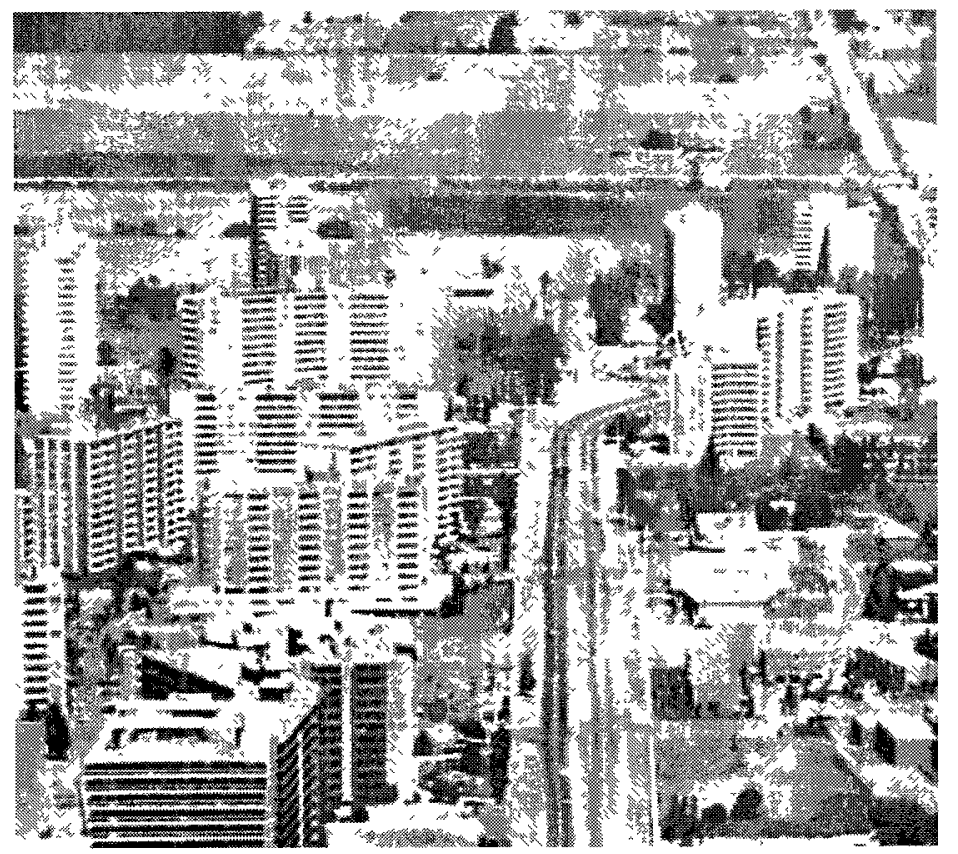

Figure 13: The Edge of Metropolitan Toronto

Bathurst and Steeles, 1960s

Consequently, Toronto is the only suburban landscape in North America where a never-ending sea of bungalows coexists with high-rises. Toronto's suburbs more closely resemble those of Paris, Belgrade or Moscow than the suburbs of its American neighbours. ${ }^{115}$ Additionally, the suburbs of the ' $60 \mathrm{~s}$ and $70 \mathrm{~s}$ included shopping centres, religious institutions, community facilities, transportation infrastructure and universities.

\footnotetext{
114 John Barber. Neglected High-Rises Hold the Key to a Sustainable Future. The Globe and Mail, May 27, 2007.

${ }^{115}$ Michael McClelland, and Graeme Stewart. Concrete Toronto: a Guidebook to Concrete Architecture from the Fifties to the Seventies. Toronto: Coach House, 2007: 215.
} 
"In Toronto, an unusually large number of high-rise apartments poke above the flat landscape many miles from downtown.... This is a type of highdensity suburban development far more progressive and able to deal with future than the endless sprawl of the U.S."116

Buckminster Fuller, 1968

When originally built, these high-rise buildings were ultra modern; they symbolized a new world and a nation confident after the war. The high-rise was the best solution for mass housing and designed to contain floods of inhabitants within Metro Toronto. ${ }^{117}$ High-rises not only provided an abundance of rental units but also helped organize them into high-density concentrations to better align with Metro services. European efforts such as the high-rise New Town of Vallingby, in Sweden, and London's Roehampton: both illustrate a bold change in suburban planning internationally, ${ }^{118}$ partly influenced Metro's approach. The suburban highrise became the most popular housing type in Toronto for a period of about 20 years, representing about $60 \%$ of the development at the time. 30,000 high-rise units were built in 1968 alone. $^{119}$ Apartment buildings were popular with business travelers, new immigrants, young, childless couples and single women. Sites surrounding highways, arterials, ravines and the edges of bungalow communities were flagged by planners as preferred zones for apartment development and developers happily listened. In contrast with other North American cities fewer than $20 \%$ of Toronto's renters actually reside within downtown; the bulk live in suburban rental units. Arguably, without the densities produced by the high-rises, transit in the suburbs would be less sustainable and the whole Toronto region would have sprawled more than imaginable. Neglect of the 'park' spaces around the tower complexes, however, has resulted in acres of underutilized land.

At the same time that planners attempted to control the form of development, provincial programs encouraged low-density development beyond Metro Toronto's boundaries. While not against growth per se, urban reformers in Toronto opposed the low-density, car-dependant development taking form beyond Metro's planning jurisdiction. ${ }^{120}$ They favoured the European growth models (to which many had been exposed) that privileged higher densities, public transit, vibrant street life; they found inspiration in the ideas of urbanist Jane Jacobs, who lived

\footnotetext{
${ }^{116}$ Fuller Geometric, Architects, Engineers, Planners, Project Toronto, A Study Proposal for the Future Development and Design of Toronto. Cabridge: MA, 1968.

${ }^{117}$ Alana Wilcox, Christina Palassio, and Jonny Dovercourt. GreenTOpia: towards a Sustainable Toronto. Toronto: Coach House, 2007:133.

${ }^{118}$ Michael McClelland, and Graeme Stewart. Concrete Toronto: a Guidebook to Concrete Architecture from 119 IBID, 214 the Fifties to the Seventies. Toronto: Coach House, 2007: 214.

${ }^{120}$ Richard White. Urban Infrastructure and Urban Growth in the Toronto Region, 1950's to the 1990's. Toronto: Neptis Foundation, 2003: 56.
} 
in Toronto at the time. Suburban development leaped or spread beyond the boundaries set by the planning control of Metro Toronto. Growth within Metro in the mid 1970s all but halted, despite an abundance of available space. It was a significant point of frustration that Toronto's residents subsidized development outside the boundaries of Metro Toronto through levies and provincial taxes. ${ }^{121}$ The city of Toronto was twice as dense as inner ring suburbs within Metro (North York, Etobicoke, and Scarborough) and four times as dense as those outside of Metro (Halton, Peel, York, and Durham). As such, Toronto's suburbs sprawled in an inverse relationship to the subsidies they had received. Most of the development beyond Metro - the so called "905" - was at extremely low densities and would not have occurred without the subsidies they received from the Toronto taxpayers.

Attempts to address the situation, including the Toronto-Centred Region (TCR) plan, had little effect. With the help of provincially funded water and sewer infrastructure, farmland beyond Metro turned into suburban subdivisions at rates as high as 14 acres per hour. In 1978, the Ontario government set out the Food Land Guidelines that gave high priority protection of productive land "to ensure the best lands are kept for agricultural use." (Ministry of agriculture and Food 1978, Section 3.2) These guidelines, however, were never enforced.

If density is a measure of sprawl, however, even with the lower density development beyond the boundaries of Metro, the Toronto region was twice as dense or half as sprawling as development in most American cities. ${ }^{122}$ Metro Toronto consisted of fewer than 50 square miles, at a density of 20,000 persons per square mile. ${ }^{123}$ By the end of the 1990 s, the actual population of the urbanized areas was 5 million - half located within the former Metro Toronto and half outside, on the fringes. Almost all of the new growth beyond Metro (or what became in the late 1990's the amalgamated City of Toronto) has occurred at densities between 6-10 residential units per acre - about double the density of suburban growth in the United States. ${ }^{124}$

As a result, Toronto's urban densities reduced, and rural densities rose, giving both a suburban quality that compromised the traditional character of the city and countryside. Without government policies, Toronto's existing buildings and neighbourhoods would have remained compact and intact, upgraded and adapted by their owners as needs presented themselves. Toronto's new neighbourhoods would be at higher densities. Before the era of subsidized

\footnotetext{
${ }^{121}$ Lawrence Solomon Toronto Sprawls a History Toronto University of Toronto, 200771

122 Joe Berride, Suburbıa Forever, Literary Review of Canada 15, no 7 (September 2007), 24-6 See also Pamela Blais, Inching Towards Sustamabilty. The Evolving Urban Structures of the GTA (Toronto Neptis Foudation, 2000)]

${ }^{123}$ John Sewell The Shape of the Suburbs Understanding Toronto's Sprawl Toronto University of Toronto, 200912

124 IBID, 158
} 
sprawl, the suburbs developed compactly along transportation corridors. Had the provincial policies not sabotaged the dense city model, Metro Toronto could have housed the population that moved to the edge within its boundaries, making Toronto as compact as equivalent areas in New York, Paris and Milan.

Although Toronto had great aspirations to high-density compact planning, it was never fully realized. That said, density alone cannot create the urban qualities that Metro Toronto was trying to achieve. In retrospect, it is far from clear whether high-rises especially in the clusters promoted by Metro's post-war planners - could have provided the kinds of integrated, pedestrian-friendly environments we associate with high-density planning. 


\section{Project of Architecture}

Following the Second World War, large numbers of Torontonians moved to detached houses on relatively large lots at the suburban periphery. Metro planners, highly influenced by Le Corbusier and Western European models after World War II, attempted to constrain and control suburban expansion with the goal of achieving higher density and greater mix of tenancy options that were available in American suburbs. As discussed, their plan was to add density to the compact designated planning region by incorporating clusters of high-rises. The result, although unique, did not produce a successful suburban landscape. Meanwhile, planners succumbed to provincial policies that funded infrastructure beyond Metro in the area known as the "905." 125 There were ongoing concerns that too much land was being swallowed up by suburban development, and that the densities especially beyond Metro were too low. Developers happily responded to the call for greater densities. Their solution was to shove more houses closer together onto smaller lots to increase densities and create higher profit margins - a favourable solution from a developers' perspective. Although there was an increase in density to about 10 units per acre, the amenities and services traditionally associated with these densities were not located within walking distance of most residential subdivisions. Accordingly, the result was neither prototypically suburban by postwar standards, nor was it urban. Neither the Metro planners' approach of using towers to up densities nor the current practice of decreasing lot sizes has produced suitable or sustainable forms of development.

New Urbanism, as discussed in an earlier section, has struggled to define appropriate forms for density developments. They weighed in on this issue by implementing form based codes and the Transect principle. Toronto area NU developments like Cornell, in Markham, do not implement NU principles as successfully as on paper. While in the United States, New Urbanist communities tend to be denser than surrounding suburban subdivisions; this is not the case in Toronto, primarily because the existing suburban development is already twice as dense as analogous development in America. NU developments like Cornell are neither more dense than surrounding subdivisions, nor are they intense enough to support a real mix of uses. Cornell, like most NU projects, is a pre-planned greenfield development at the periphery. Public transit is not viable unless significantly subsidized by the city.

125 “905": The area-code of the region beyond Metro Toronto's boundaries. 
It was not my intention to use the design portion of this thesis to propose a new city centre, nor have I attempted to create a new community, neighbourhood, or subdivision. Rather the goal was to augment an existing community from within using underdeveloped land. Ebenezer Howard reinforced the importance of complete communities - of towns that incorporated all aspects of life - and the $20^{\text {th }}$ century has witnessed an ongoing struggle to find a balance between urban and rural living. For over a century intellectuals, critics, planners, and architects have attempted to make suburbs better places by responding to the needs and wants of citizens. Keeping that in mind, I have left the task of designing new communities to others, and instead focused my attention on an existing community. Following the recommendations of Clarence Perry and Clarence Stein, I believe that the neighbourhood unit is the essential building block of communities and the appropriate scale to address the "repurposing" of suburbia.

Greyfield or vacant sites do not just affect the adjacent spaces; they can disrupt the whole neighbourhood network. As Emily Talen has notes, 'putting back the 'missing teeth' is one way to repair the seams." ${ }^{126}$ Along major corridors connected to transit are locations that to target for increased density, and are in dire need of retrofitting. Essentially, the thesis explains the creation of prototypical nodes (centrums or village centres) on prime, underutilized land, to support live, work, and play spaces. The nodes add to existing neighbourhoods by providing essential services they currently lack, as well as expanding living options, reducing dependency on automobiles, developing social networks, creating a better quality of life for inhabitants, and encouraging social interaction within the community. The vast majority of growth in North American cities in the past century has taken shape on greenfield sites. The time has come to repurpose or retrofit suburban communities, beginning with greyfields. Civilization rebuilds every 50-60 years, ${ }^{127}$ thus it is time to rethink and appropriate the suburban landscape. The aim is to breathe new life into aging districts, to effect change from within.

Although the Shops at Don Mills (discussed in Chapter 3 ) is well-intentioned, the local community has lost its meeting place. The new centre targets a larger, regional demographic that can afford the high-end stores, cafes, and restaurants. If its attempt was to create an urbanized downtown neighbourhood, the density of the project is too low. The majority of the buildings on the site are single-storey retail. An opportunity was lost to take advantage of proper mixing of uses and overlapping functions (although this may come in time). While the

\footnotetext{
${ }^{126}$ Emily Talen. Design for Diversity: Exploring Socially Mixed Neighborhoods. Amsterdam: Architectural, $2008: 173$.

${ }^{127}$ Andres Duany, Elizabeth Plater-Zyberk, and Jeff Speck. Suburban Nation: the Rise of Sprawl and the Decline of the American Dream. New York: North Point, 2000.
} 
Shops at Don Mills is a step in the right direction it suffers from many of the same problems as a shopping mall. The site is inward facing, like its predecessors. The project does not hold the street; there is little interest at the edge to generate pedestrian activity, primarily because parking lots mainly surround the project. In actuality, the shops are less dense then before and have the feeling of big box retail masked as local shops. A mix of uses and neighbourhood services envisioned by E.P Taylor and Macklin Hancock must be incorporated. Unlike the Shops at Don Mills, Reston Town Centre was constructed at high densities with mixes of uses, and public spaces for people to linger. The goal of my proposal is to incorporate the qualities and characteristics that work at both the Shops at Don Mills and Reston Town Centre into smaller, village centres or nodes that augment and intensify existing neighbourhoods.

Emily Talen identifies two types of strategies to support diversity: the mix of housing options and the mix of services and facilities needed to support a diverse set of needs. ${ }^{128}$ It is important to mix housing sizes, prices, types and tenancy options to build a place that people of different demographics can call home. The thesis aims to create a node that can accommodate the suburban nuclear family, newlyweds, childless couples, bachelors, young professionals, students, seniors, and empty nesters. A mix of people augments the diversity, liveliness and civil character of the space. Moreover, the additional density supports a wider variety of services and amenities. The reduced percentage of households with children, the growing market for multi-unit housing, the growth in the percentage of jobs in suburban locations, the rise oil prices, and an increased demand to live near transit, all make the proposed project a viable alternative for future development.

Jane Jacobs argues that there was logic to mixed-use where healthy urbanism is concerned. Identifying dynamic synergies between uses create a successful mix. For example residential attracts retail, retail supports office, office supplies restaurants, and restaurants attract residential. ${ }^{129}$ Combining uses vertically, compactly and creatively produces new efficiencies of land use and shared infrastructure. Now uses can be cross-wired to produce unanticipated social and spatial relationships.

Cultural and community facilities, as well as communal play spaces connect people. Spaces specifically designed for children are essential since children are a vital ingredient to forming social connections, ${ }^{130}$ and because kids need protected places to play. Currently there are few places in the middle-class suburban environment for teenagers. There is a need for

\footnotetext{
${ }^{128}$ Emily Talen. Design for Diversity: Exploring Socially Mixed Neighborhoods. Amsterdam: Architectural, $2008: 115$. 129 IBID, 109.

130 IBID, 160.
} 
more facilities and better access to existing ones. Only an extensive 'mix' can generate densities, intensities, and frequencies of use to create meaningful compact places.

Underdeveloped sites, located along major corridors regardless of their size and shape can create prototypical intensification nodes. Nodes rely on a network of interconnected streets with plentiful links to provide optimal circulation for both pedestrians and motorists. Vallingby is not only a high-density, diverse, mixed-use development; it is also one of several nodes along a transit line (incorporating transit-oriented development); connection emphasized both within and between communities/nodes. Characteristics and strategies implemented at Vallingby, along with other vital qualities mentioned above helped in the creation of the formula below. Applying the formula to each site will support the creation of a desirable community and can help guide the suburbs into the future.

\section{NEW FORMULA FOR PROTOTYPICAL GREYFIELD REPURPOSING}

(RETAIL/COMMERCIAL (AMENITIES) + RESIDENTIAL + COMMUNITY/CULTURAL SERVICES + MEDICAL/OFFICE SPACE + SEPARATION OF CAR AND PEDESTRIAN PATH + PUBLIC SPACE + STREET FURNITURE + NATURE + TRANSIT CONNECTION) $=$ FUTURE DEVELOPED SITES ${ }^{131}$

While the formulas intent is as a minimum, a guide, a recommendation - specific location and site conditions take priority. I have applied this formula to a specific site in order to better understand and assess it. On a micro level, the conveniently located sites along suburban transportation corridors are within walking distance of surrounding neighbourhoods, and provide fundamental services connected to transit. On a macro level, the interconnection of highdensity, mixed-use nodes help to transform the larger low-density "suburban" fabric into something that functions more like a city without threatening the appeal or integrity of the adjacent single-family neighbourhoods.

\footnotetext{
${ }^{131}$ Formula based on research and site studies of streetcar suburbs and of postwar suburban environments
} 


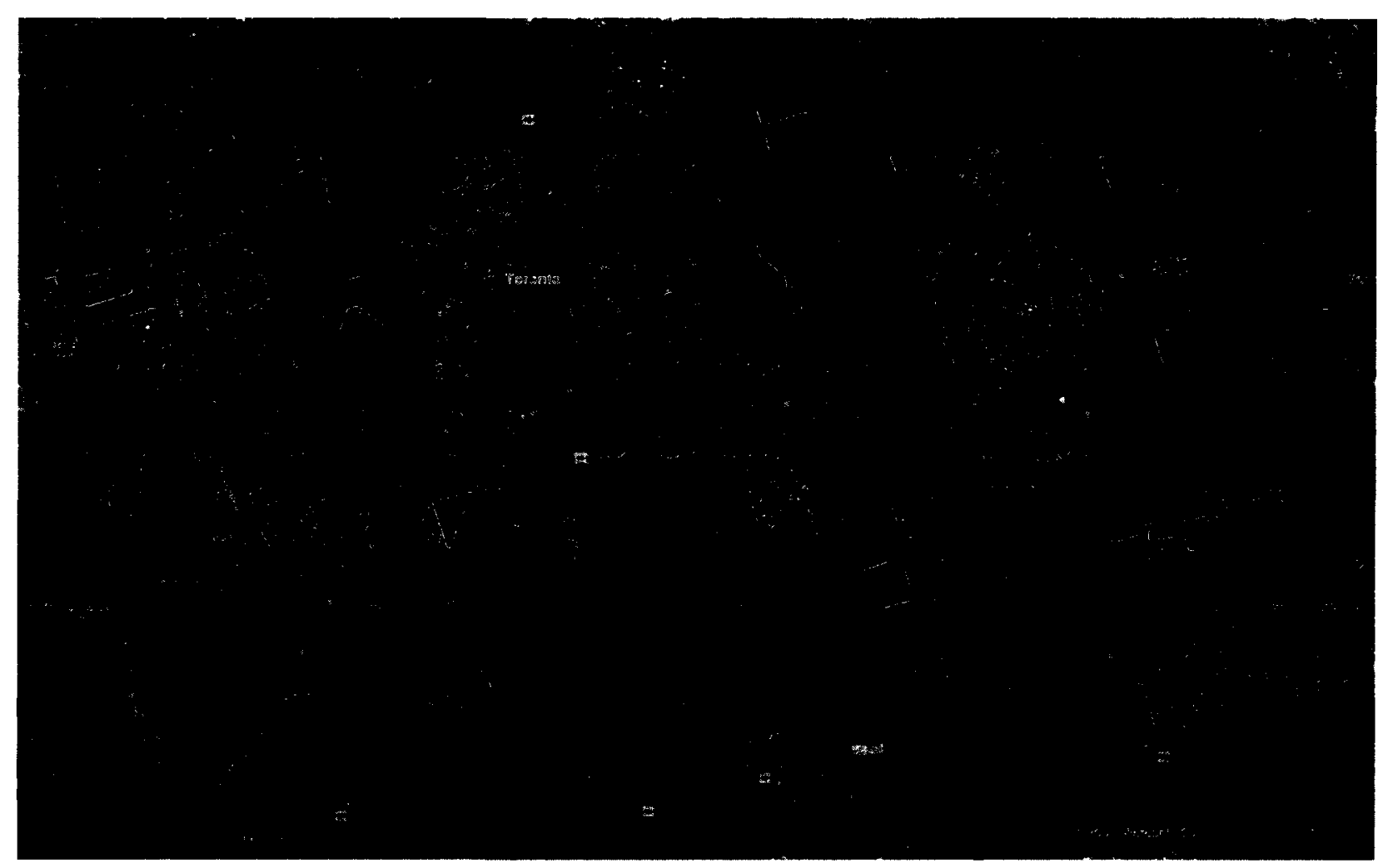

Figure 14: Potentiality of the Prototypical Nodes

View of a portion of the Toronto suburbs

Red: indicates the sheer quantity of potentially available greyfield sites in need of repurposing

Turquoise: indicates the location of the site being investigated in this thesis

Blue: indicates the areas that are within a 5 minute walk to prospective greyfield sites

Yellow: indentifies the areas that are within a 10 minute walk to prospective greyfield sites

\section{SITE ANALYSIS}

The project is located in a suburb of Toronto, on a single-use site, at the corner of Victoria Park Avenue and Sheppard Avenue. Currently, Food Basics (grocery store), restaurant, Bank of Montreal, Chuck E. Cheese, Winners, Petro-Canada, and a small hairdresser occupy the site. Compared to 15-20 years ago the plaza has lost customers. Pedestrian access from the adjacent neighbourhoods is non-existent; a hidden staircase provides the only connection. The plaza turns its back on residents reducing accessibility; and is set deep within a huge area of parking with no designated paths for pedestrians to approach the stores. The plaza is clearly designed for automobiles.

The site is located at the intersection of two transit-served main streets. Furthermore, the site is surrounded by typical suburban elements, including several that are typical to Toronto. Every use is segregated. Residential subdivisions surround the site to the northwest. Apartment buildings straddle the site across Victoria Park Ave. to the east, and are surrounded 
by additional residential subdivisions. Across Sheppard Ave. to the south is a business park. Smaller commercial strips with residential subdivisions are located southeast of the site. Within the surrounding subdivisions, nothing is accessible by foot except neighbourhood elementary schools and a couple of deserted parks. Errands and trips to the community centre or recreational facilities would involve a 5-10 minute drive.

The Toronto Transit Commission (TTC) has started construction on a light rail line that would run along Sheppard Avenue East, replacing the existing busy bus route. The light rail will connect to Don Mills Subway Station, Go Train, and various other bus routes. However, the new Mayor of Toronto Rob Ford has recently stopped the construction of the LRT line. His intention is to put the new transit route under the ground to separate transit from vehicles, and to create a faster route unaffected by streetlights and traffic. Whatever the case may be, Sheppard Avenue East has been marked as an important corridor in need of efficient public transit, and will be a significant corridor for future development that can handle greater capacity.

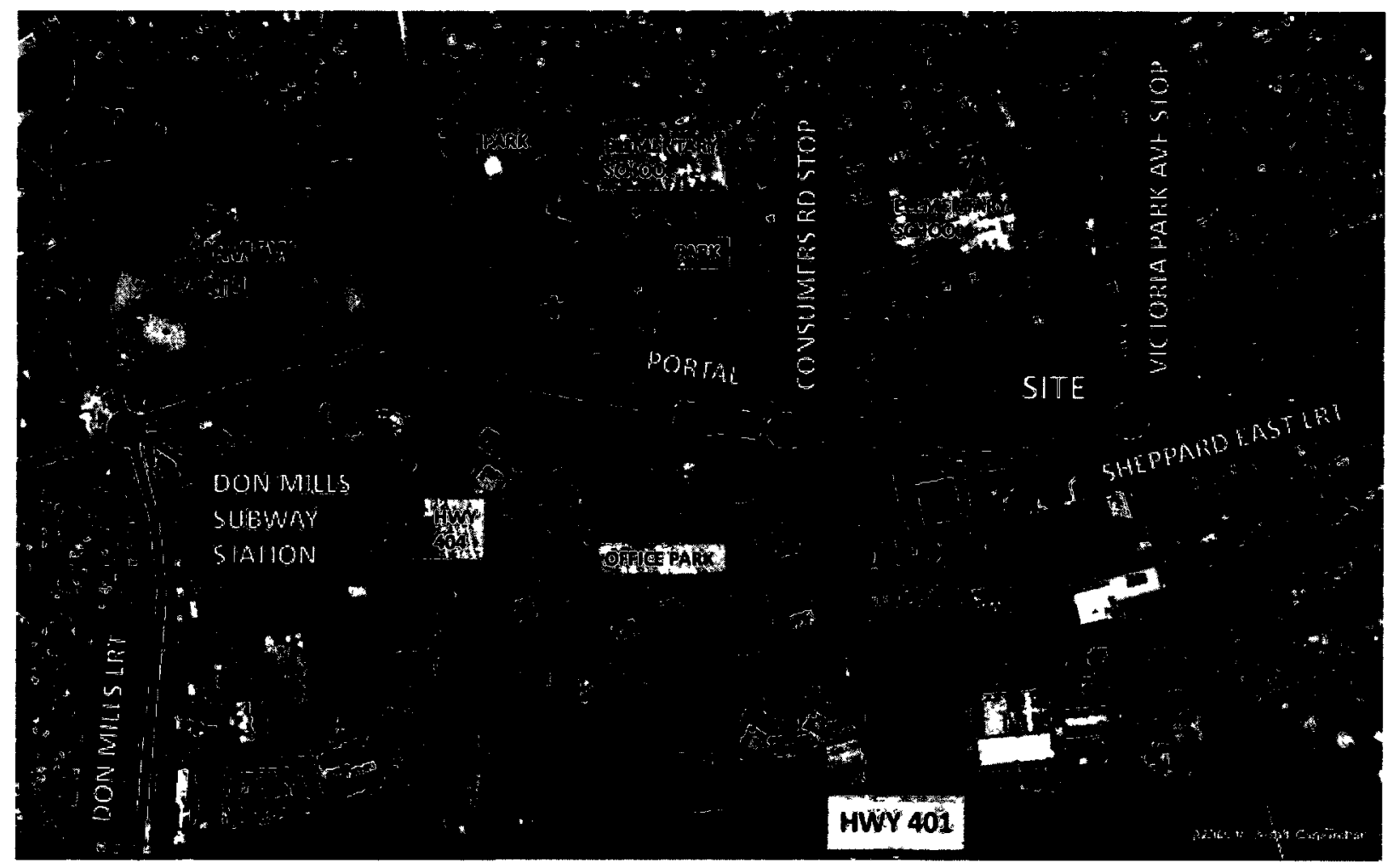

Figure 15: Overall Site Plan

Showcasing the site in relation to existing and future transit routes and connections. Note: the Portal is the point at which the LRT line goes underground. 


\section{TRANSITCITY

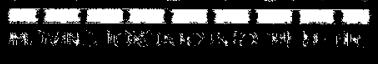

Looking West at Sheppard Avenue East and Victoria Park Avenue - BEFORE

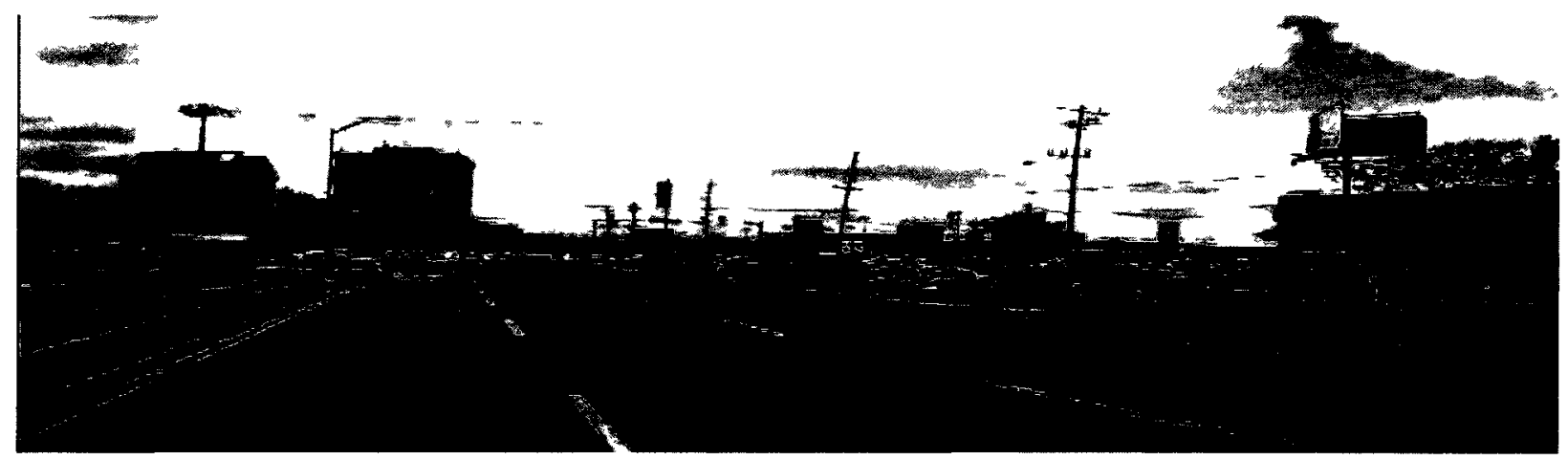

Looking West at Sheppard Avenue East and Victoria Park Avenue - AFTER CONSTRUCTION

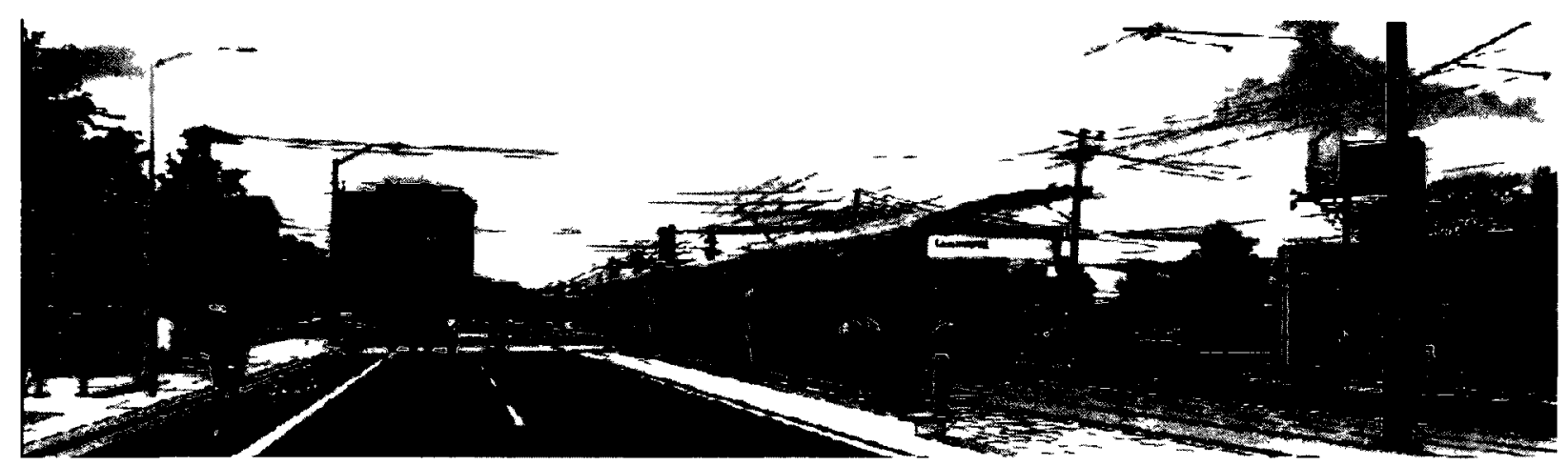

Figure 16: The Before and After look of LRT line

View of the proposed site intersection 


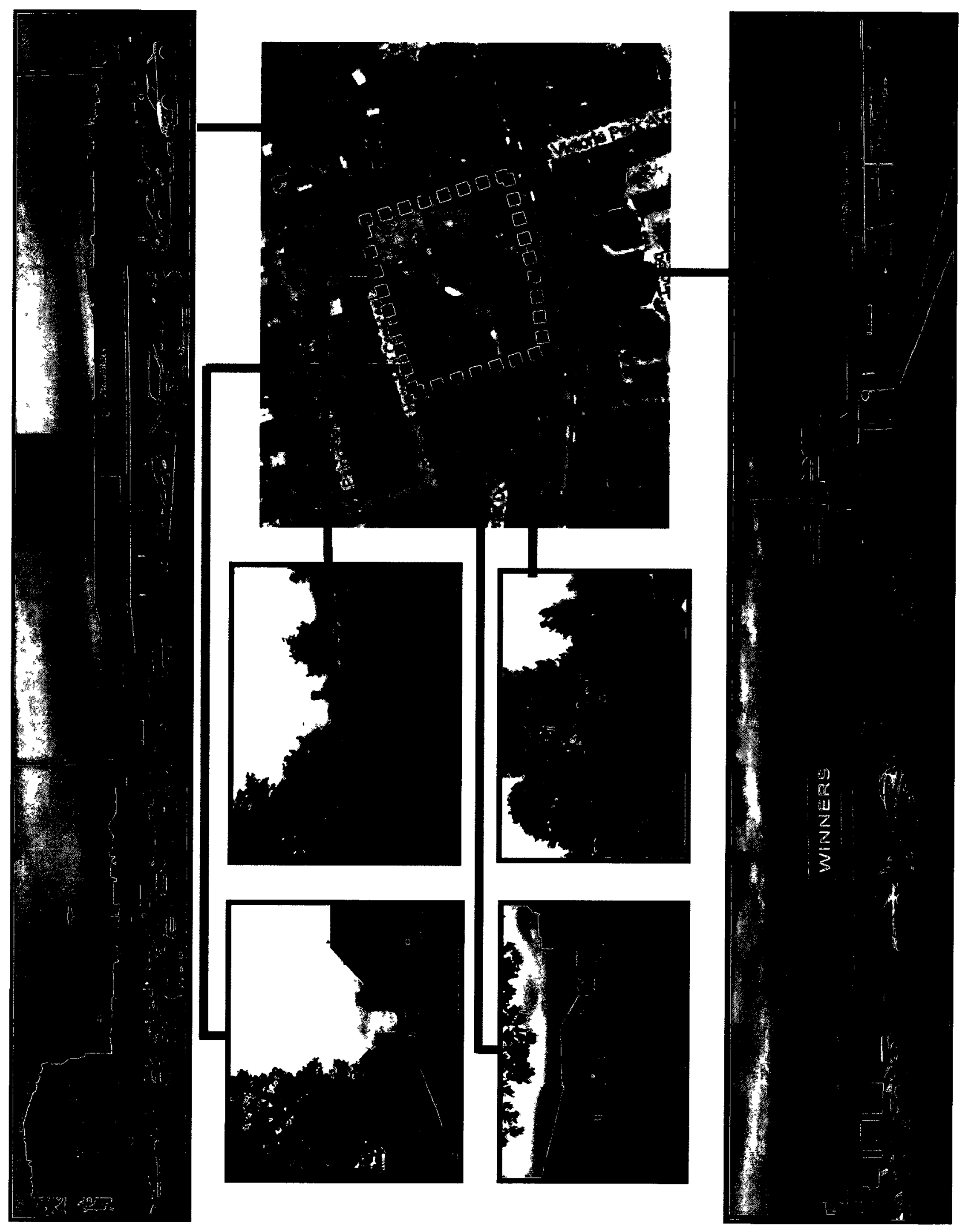

Figure 17: Existing Site Images 
The site program was based on the surrounding built environment. It was established by examining of the Census, Statistics Canada, Official Plan of Toronto, and the Neighbourhood Social Infrastructure in Toronto for the specific site area and district. The city of Toronto's population will reach an estimated 3 million persons by the year 2031. Social infrastructure must meet not only the broad needs of the general population but also the specific needs of diverse and vulnerable groups to strengthen neighbourhoods. Neighbourhoods should be inclusive, vibrant, cohesive and safe. Community services such as libraries, schools, and recreation programs are key contributors to inclusion and cohesion. Studies show that greater proximity to services increases the likelihood that individuals will receive care and use nearby services. To be most effective in building social capital it is critical that organizations and services be near the residents they intend to serve. The diagram below shows what amenities and services are available within the critical 5-10 minute walking range of the proposed site.

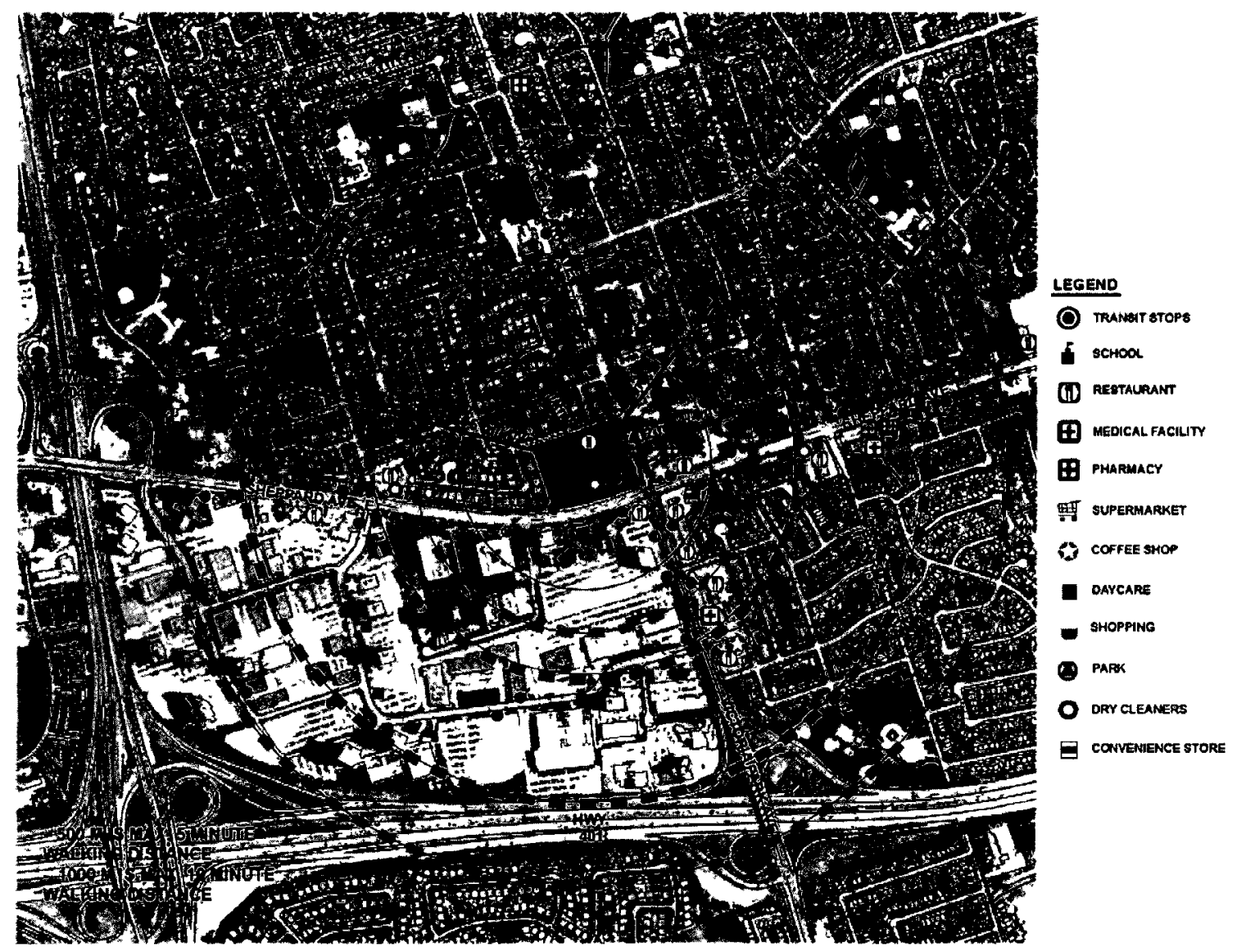

Figure 18: Ring Diagram

Pink ring: indicates Clarence Perry's 1/4-mile radius equaling a 5-minute walk.

Purple ring: the approximate distance after which point the use of services used within walking distance drops according to the Vallingby centrum.

Navy ring: indicates Clarence Perry's maximum of 1/2-mile radius equaling approximately 10 -minute walk. Green ring: indicates the maximum walking distance for uses approximately 10 minutes. 


\section{PROPOSED SITE PROGRAM}

- Grocery Store

- Bank

- Daycare

- Medical Centre

- Seniors Home

- Library

- Seniors Services

- Restaurants

- Bars/Lounges

- Cafe/Coffee Shop

- Hair Salon

- Office Space

- Butcher

- Bakery

- Community Services for Recent Immigrants

- Employment Services

- Post Office
- Retail Stores

- Cleaners

- Pet Services

- Health Food Store

- Pharmacy

- Florist

- Community Recreation Facility

- Different Residential Types

- Outdoor Skating Rink

- Market place

- Swimming Pool

- Playground

- Outdoor Movie Screening Space

- Water Feature

- Street Furniture

- Community Gardens

- Public Square

"Program based on the above Ring Diagram, the information gathered from Government and City sources as well as formula created to produce future project developments*

Architectural variety is a way of supporting diversity. Urbanists have stressed that the most important requirement for good urban places is the control of size and keeping things small. Within small neighbourhood-based establishments, trying to accommodate larger retailers can be challenging. Big box chains can be accommodated in ways that do not work against the grain of the neighbourhood scale and fabric. Some strategies are to wrap them with small units, to put smaller retail spaces in front of the big box store, or to put a small neighbourhood retail size entrance at ground level and raise the rest of the big box store above, so that it does not take away from the scale of surrounding independent stores. The plinth of one use such as commercial creates a synthetic "landscape," a new ground for residential units above. Vertical connections facilitate integration between levels and uses, where the plinth can act as meeting ground.

Transitioning between the low-density single-family homes to the higher density, street edge condition in a respectable way will be the challenge. It is important that buildings and 
services do not turn their back to surroundings, but instead integrate and connect with the existing local community. The series of schematics below play with different configurations to create a transitional link and connectivity between the existing and the new. Massing and program distribution on the site is explored. In most cases the scale of the buildings and use help with the transition. The technique implemented in the schematics was hierarchal in terms of function, shape and height. Family oriented residential units and services are connected or closer to the existing neighbourhood fabric acting as the link. Next, are the neighbourhood scale services and uses with retail/commercial at grade, and residential flats above gradually rising in height as the design works its way to the edge of the site. Finally, holding the boundary, along main corridors are programs and scales that can handle higher speeds - with retail and commercial at grade, and office space below high-rise point access towers.

\section{INITIAL SCHEMATICS}

The schematics have the following points explored and implemented within each attempt:

- Reorient the site activity to face the street rather than internal corridors. This encourages social interaction and a sense of community, as streets become properties of main civic spaces

- To differentiate between pedestrian streets from vehicle streets

- Activities and structures should integrate multiple uses both horizontally and vertically and be designed for human scale

- To have a range of housing types from maisonettes (stacked towns), to senior's residents, and apartment flats. A range of housing to accommodate as many diverse people and demographics as possible

- Create residential units that have multiple orientations thus having access to cross ventilation and natural day light

- Accommodate parking both at street level and underground where the bare minimum is provided. Because different programs are using the space at different times of the day, they can share the available parking.

- Implementation of wide sidewalks, pedestrian paths, street furniture, public civic spaces, and green space for people to interact with other, to sit, linger, and watch life go by.

- Create a gradual transition.

- Connect to public transit.

- Hold the street edges 
Schematic 1:
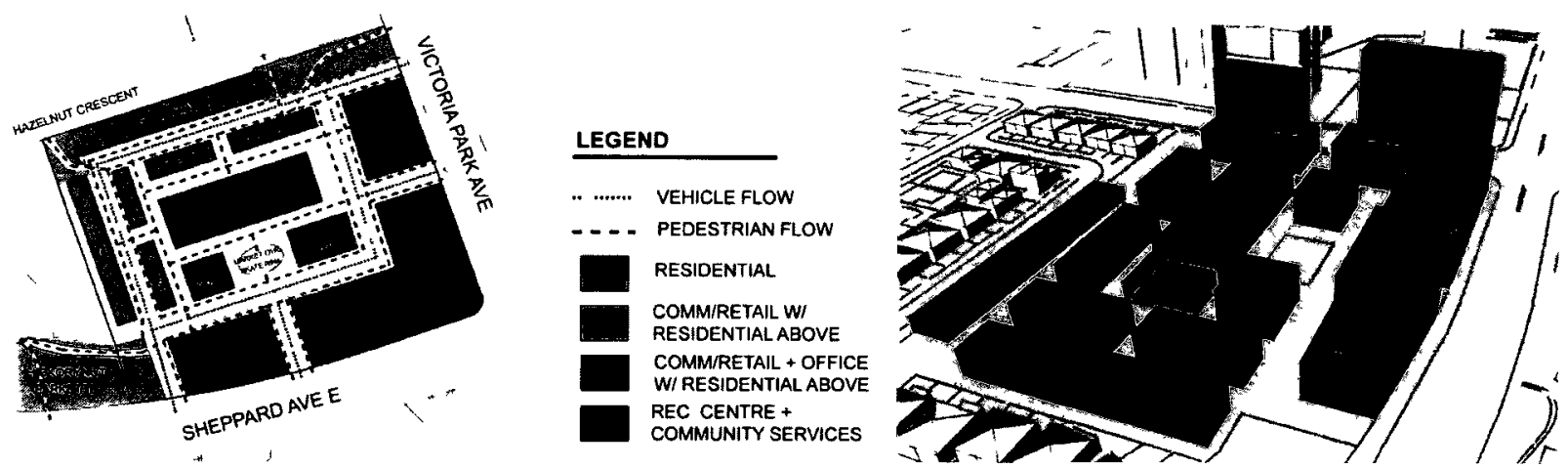

- Removes everything on the site and starts from scratch

- Puts the community centre and swimming pool at the centre of the site making it the focal point along with the central public square

- Housing includes family oriented units, stacked maisonettes, seniors housing, low-rise and high-rise apartment flats.

- Breaks up the site in smaller buildings

- Most of the buildings are too low of scale, and it is not a gradual transition

- Still has single function buildings

\section{Schematic 2:}
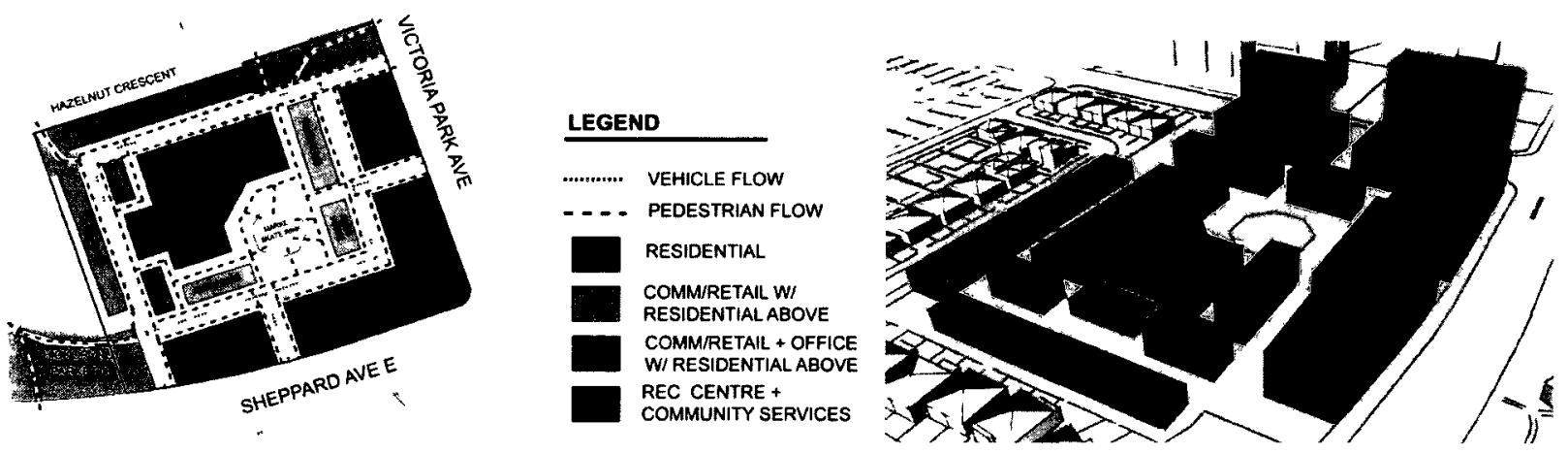

- Keeps most of existing plaza to repurpose it as a community and recreational facility

- Surrounds swimming pool by only residential units

- There are still single-use buildings

- Scale feels more like the current suburban landscape 
Schematic 3:
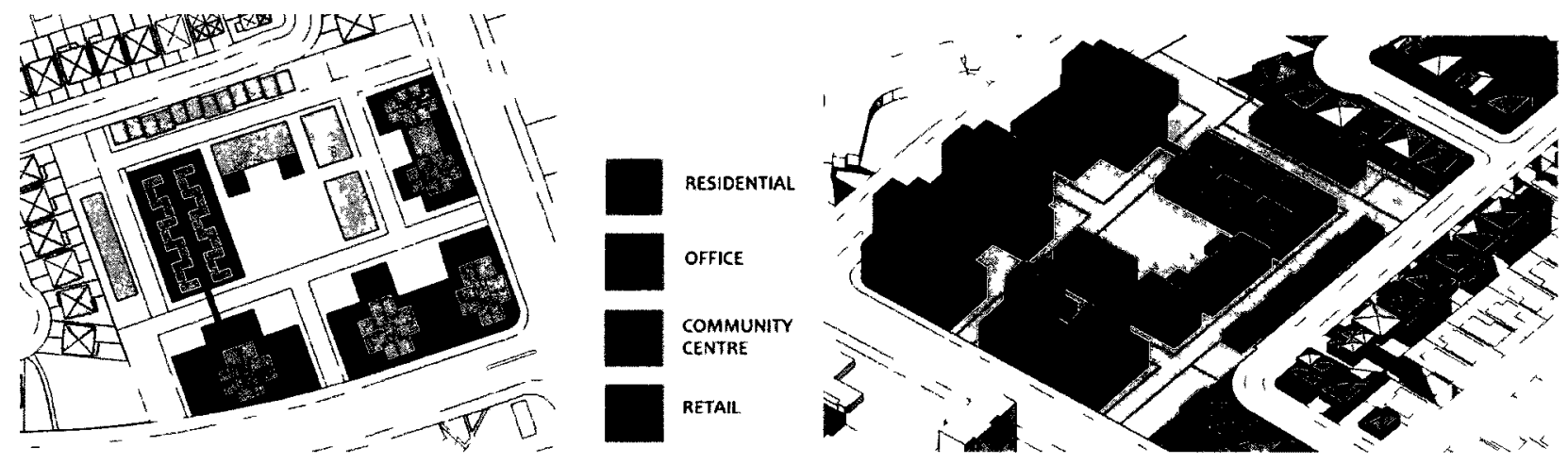

- Brings part of community centre to the edge of Sheppard Ave continuing to the building behind with town homes and maisonettes on the roof

- Creates 2 small surface parking lots that can be locations for future development

- Scale and shape of central buildings do not seem to be working

- Doesn't seem to connect well with neighbouring subdivision

- Still single use buldings at edges of the neighbourhood

- Crenellation of street edge buildings creates defined pedestrian areas

- Point access tower above community centre seems out of place at edge

Schematic 4:
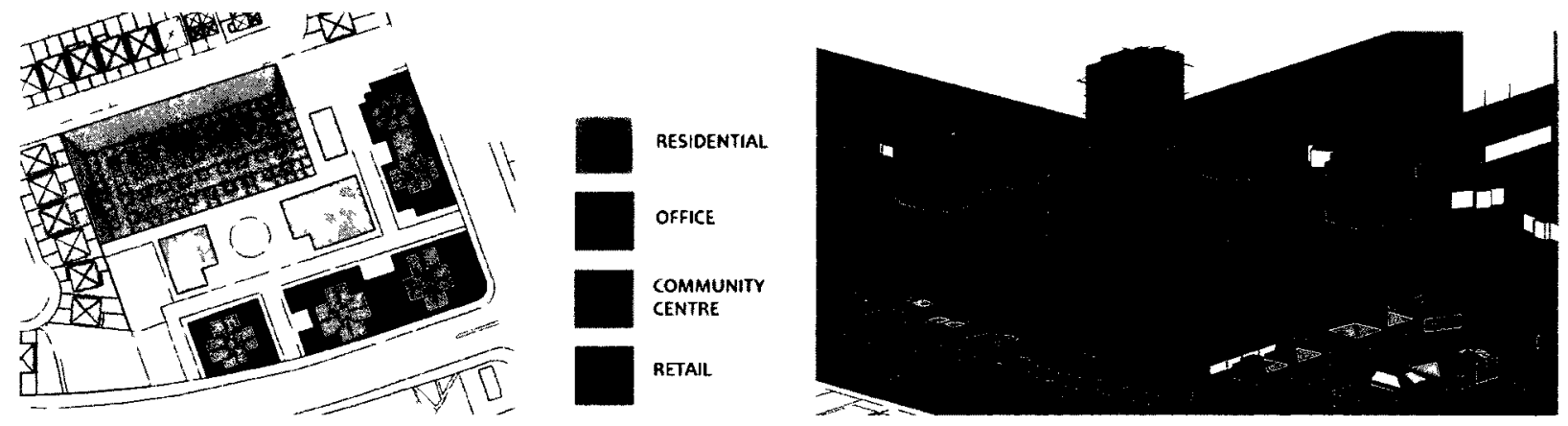

- Community centre with stepped housing on top creates a better transition and connection with housing subdivision

- Stepped housing creates substitute for single-family homes each with outdoor spaces

- Landscaped sloping creates a gradual transition and sectional and elevational interest

- Other central buildings seem too large and bulky, and seem to be of the same caliber to the buildings at edge

- Creates 2 at grade parking lots 
Schematic 5:
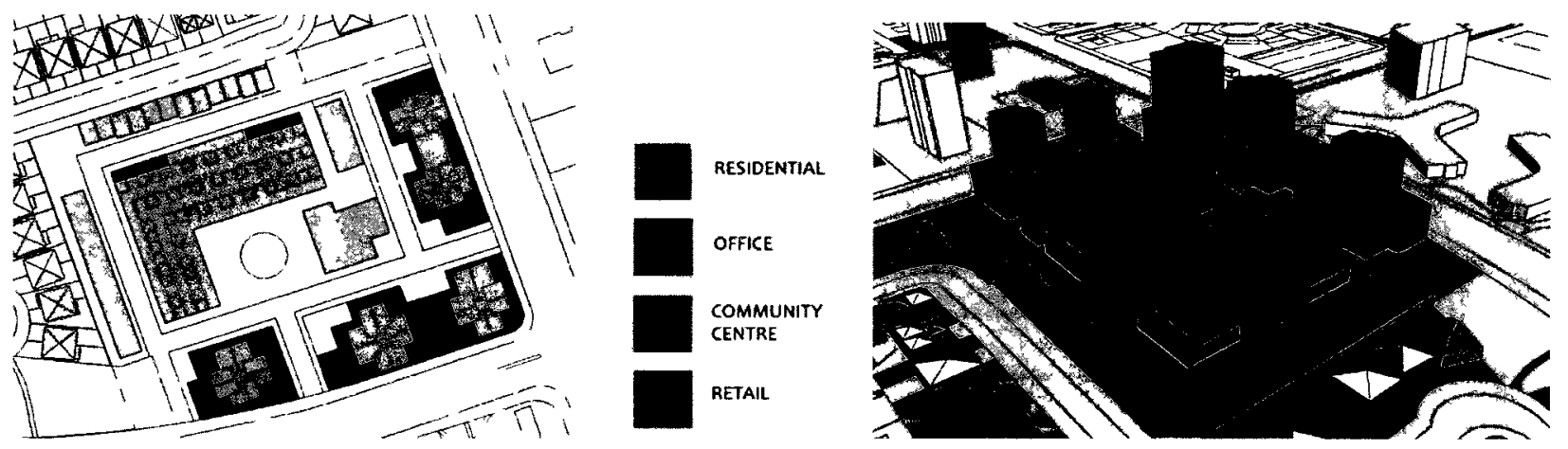

- L-shaped stepped housing above community faclity seems too static

- Each stepped housing has its own outdoor space

- Scale and shape of other central buildings seem out of place and awkward

- Does not seem well connected to neighbouring subdivision, might work better if it was shifted and closer to the edge of subdivision

\section{The Proposed Scheme}

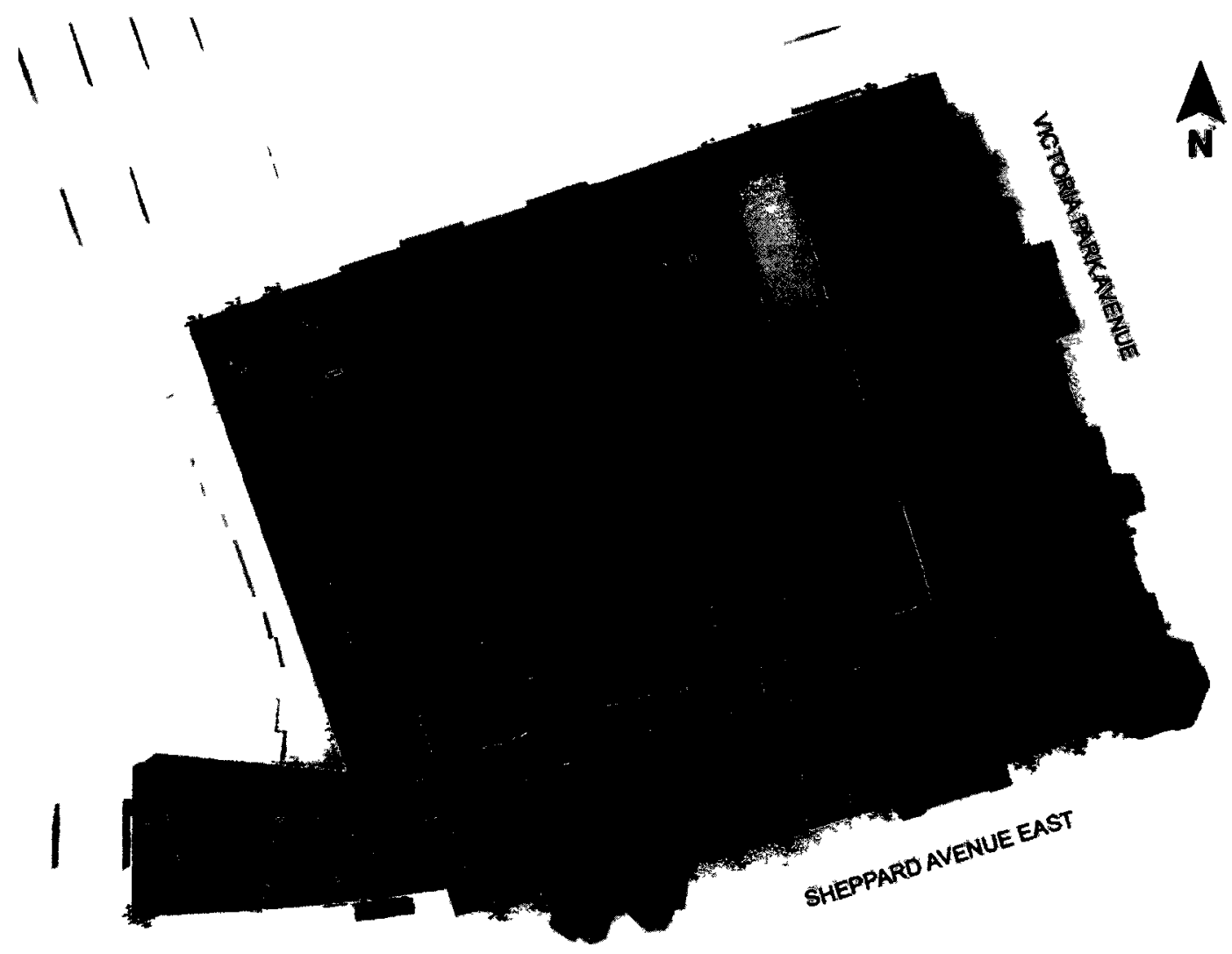

Figure 19: Proposed Plan 


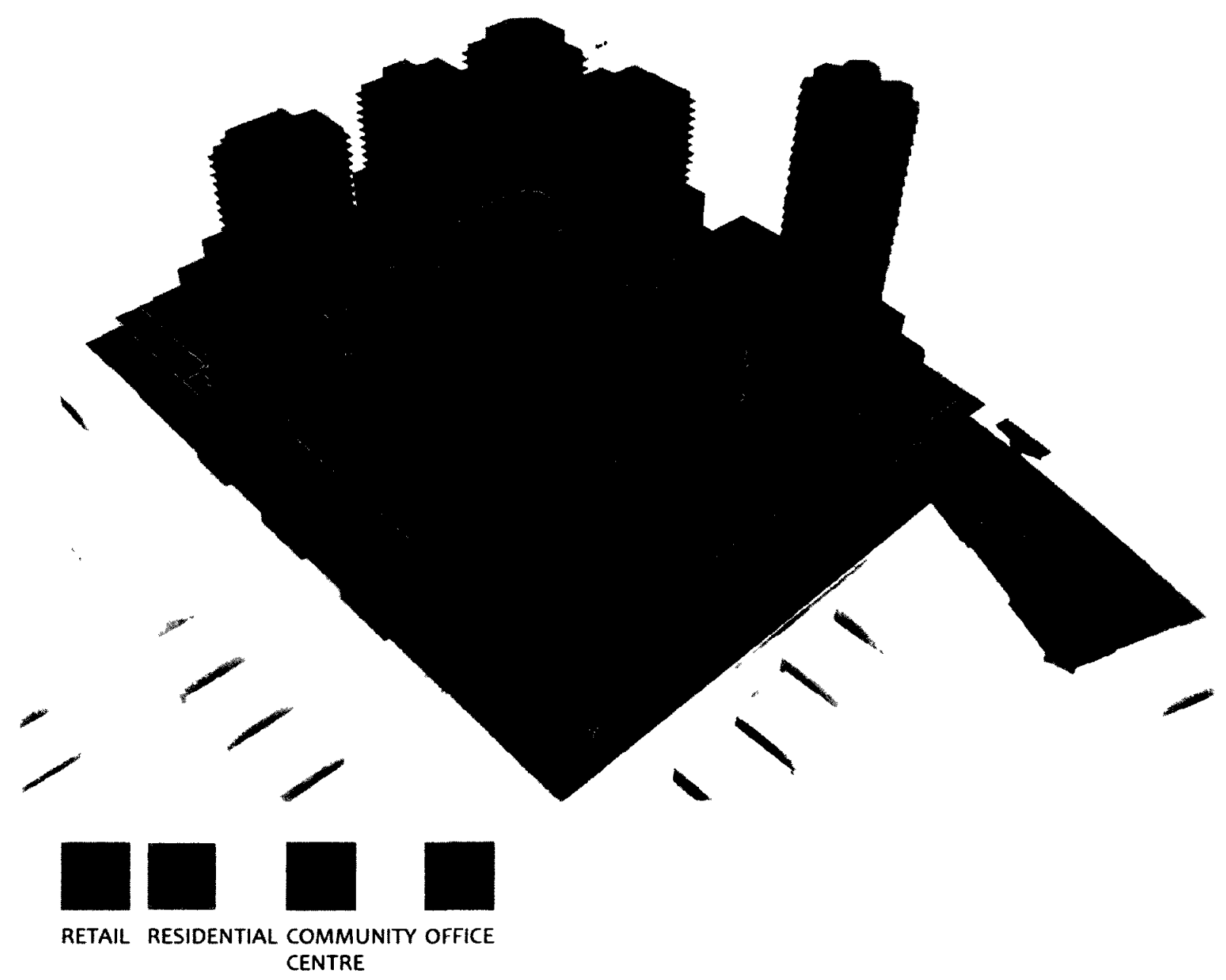

- Creates different sized variations of single family home in a mound stepped form on top of a community recreation centre

- Creates many public and green spaces including the central square

- Each mound housing unit has its own outdoor space

- Feels more transitional between the neighbouring low-density subdivision and the higher speed of the corridor

- The sizes and shapes of the other central buildings are more gradual and more similar to neighbourhood scale. Acts as a transition between the services found in a neighbourhood and to other services found at the edge

- Looking from the direction of the single-family homes the proposed project looks like it extends the suburban housing mass up the mound. Looking from the other direction the 
mound housing looks like a well defined edge shaping the main public space. Looks urban and dense.

- Can build and keep most of existing plaza if feasible
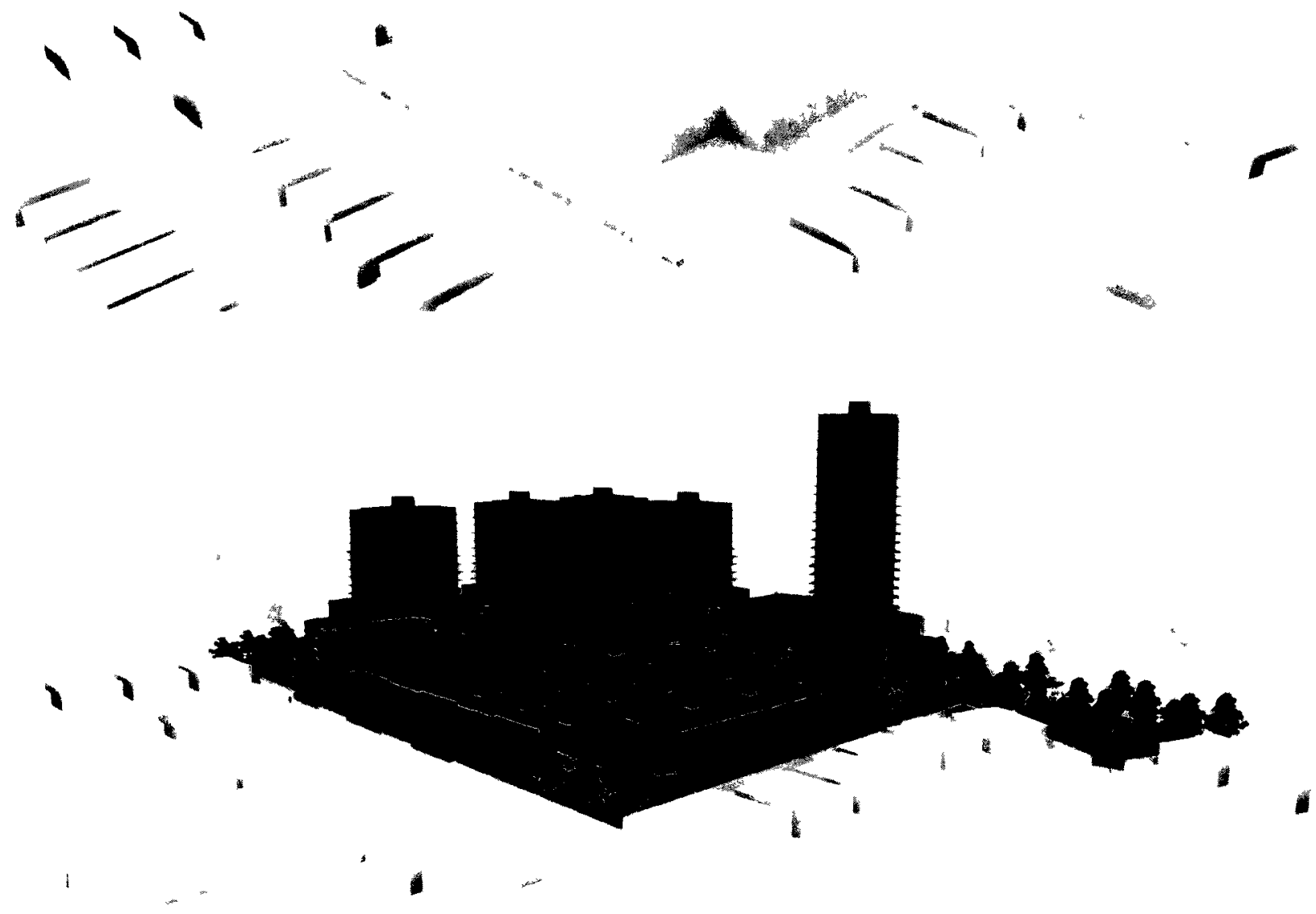

Figure 21: Before and After-1 

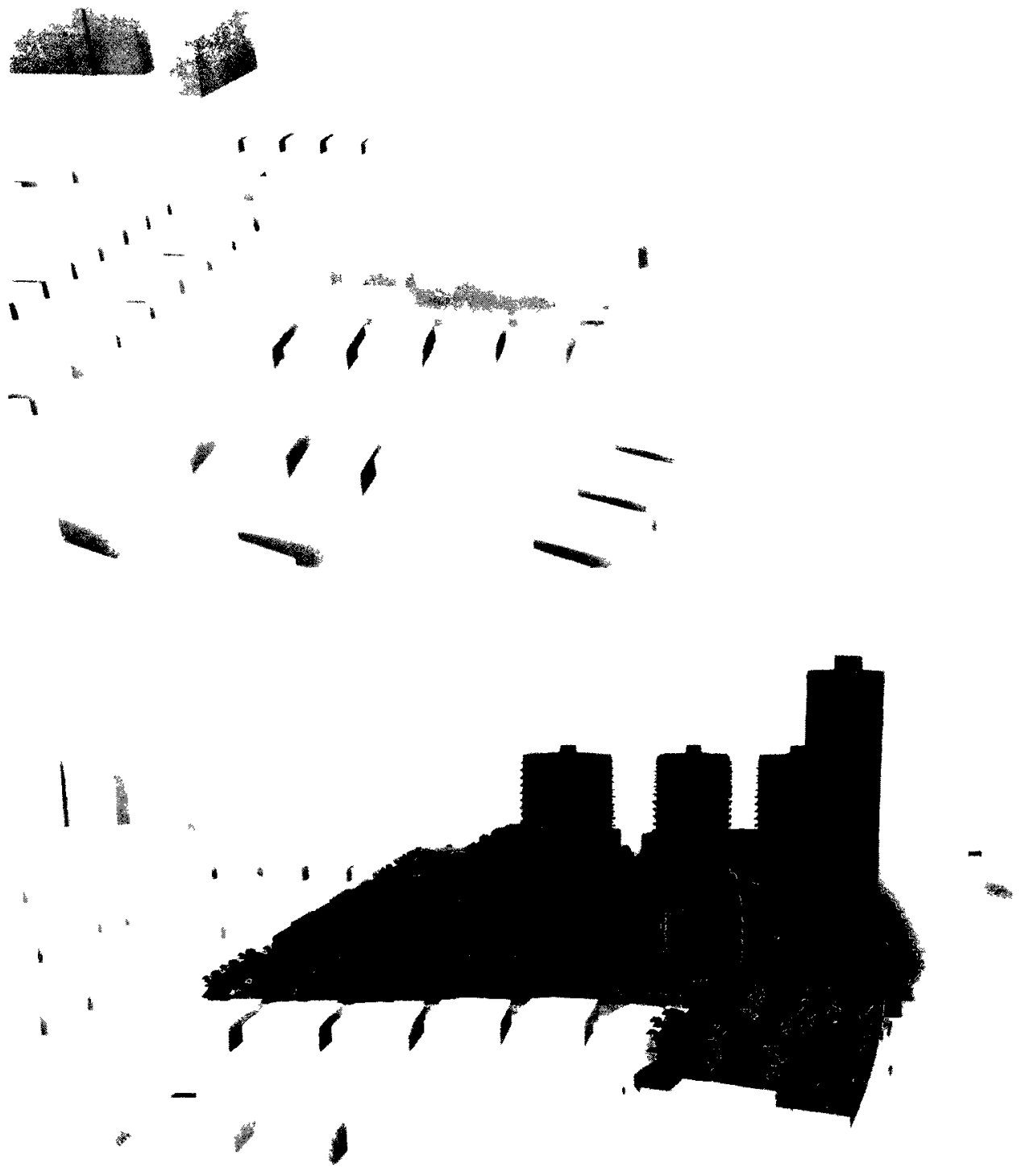

Figure 22: Before and After - 2

65 


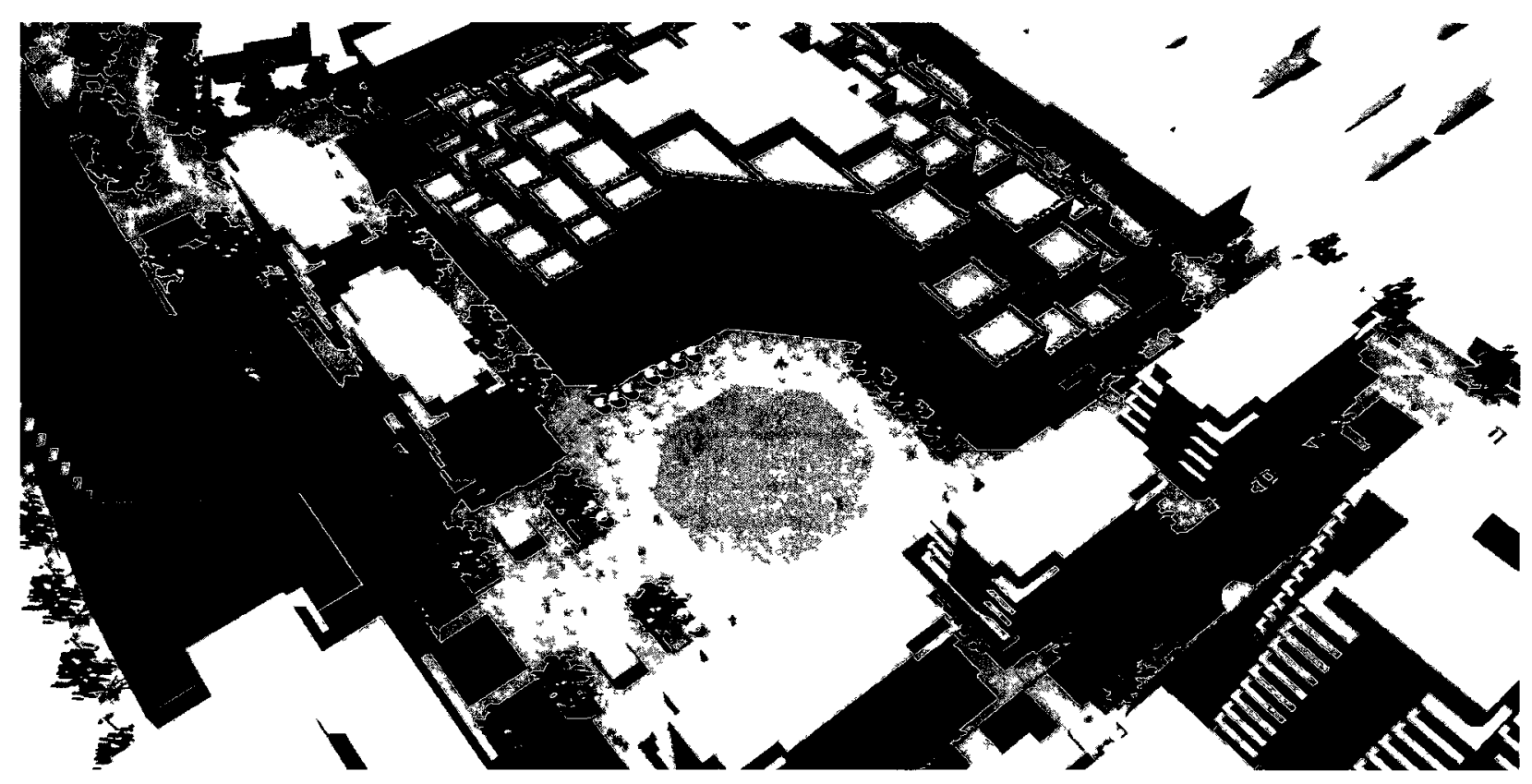

Figure 23: View of Central Public Space and Connections

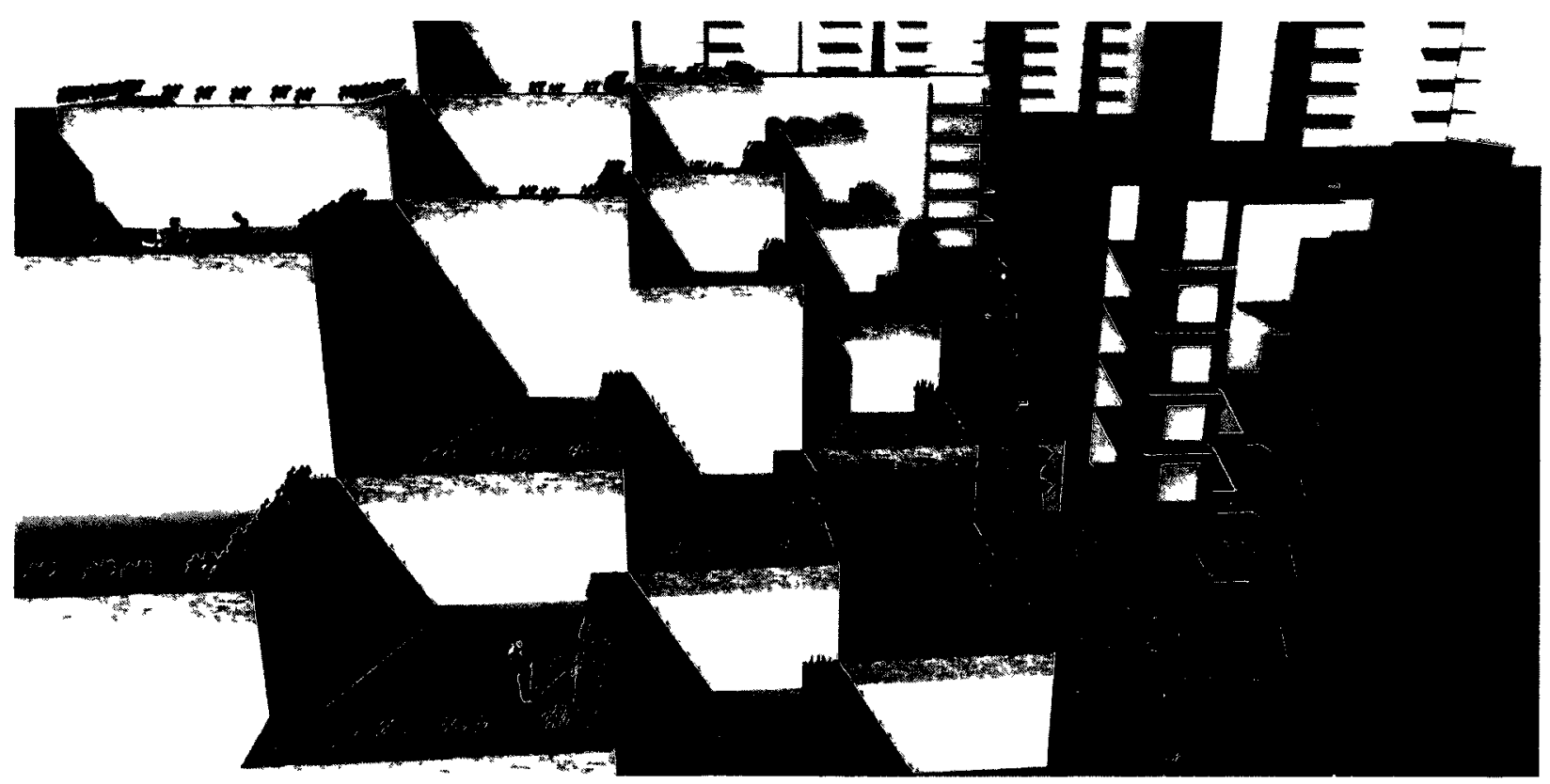

Figure 24: View of Mound Housing and Terraces 


\section{SECTION THROUGH MOUND}

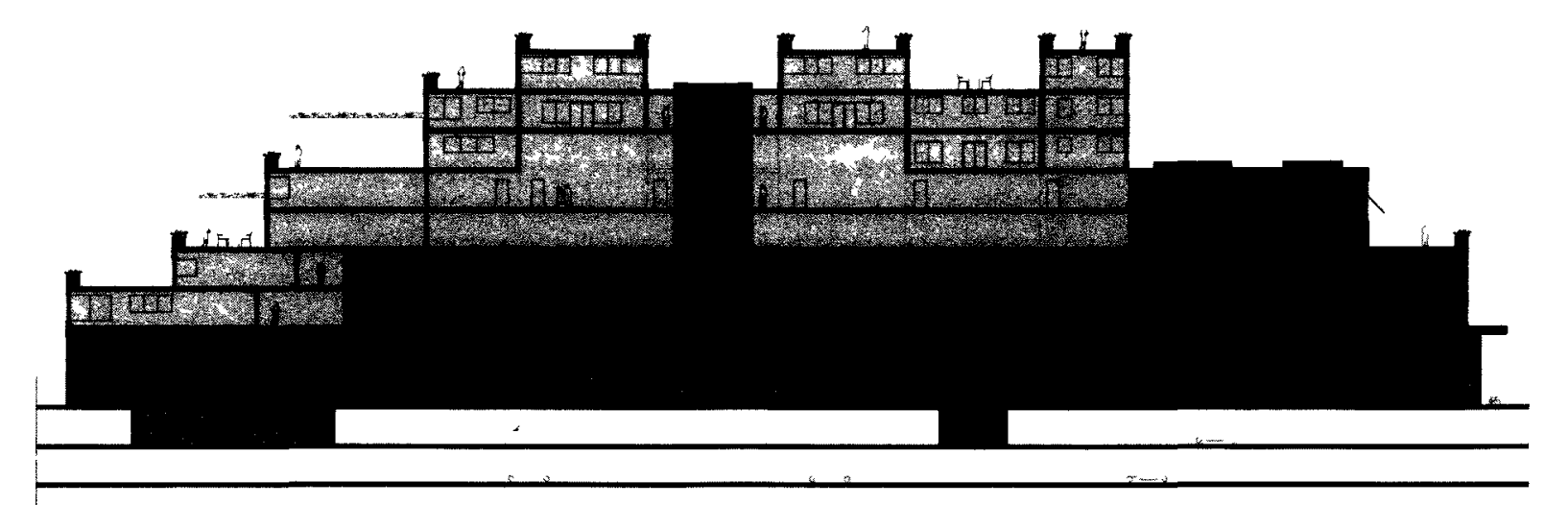

LEGEND

COMMUNITY CENTRE

等端 RESIDENTIAL
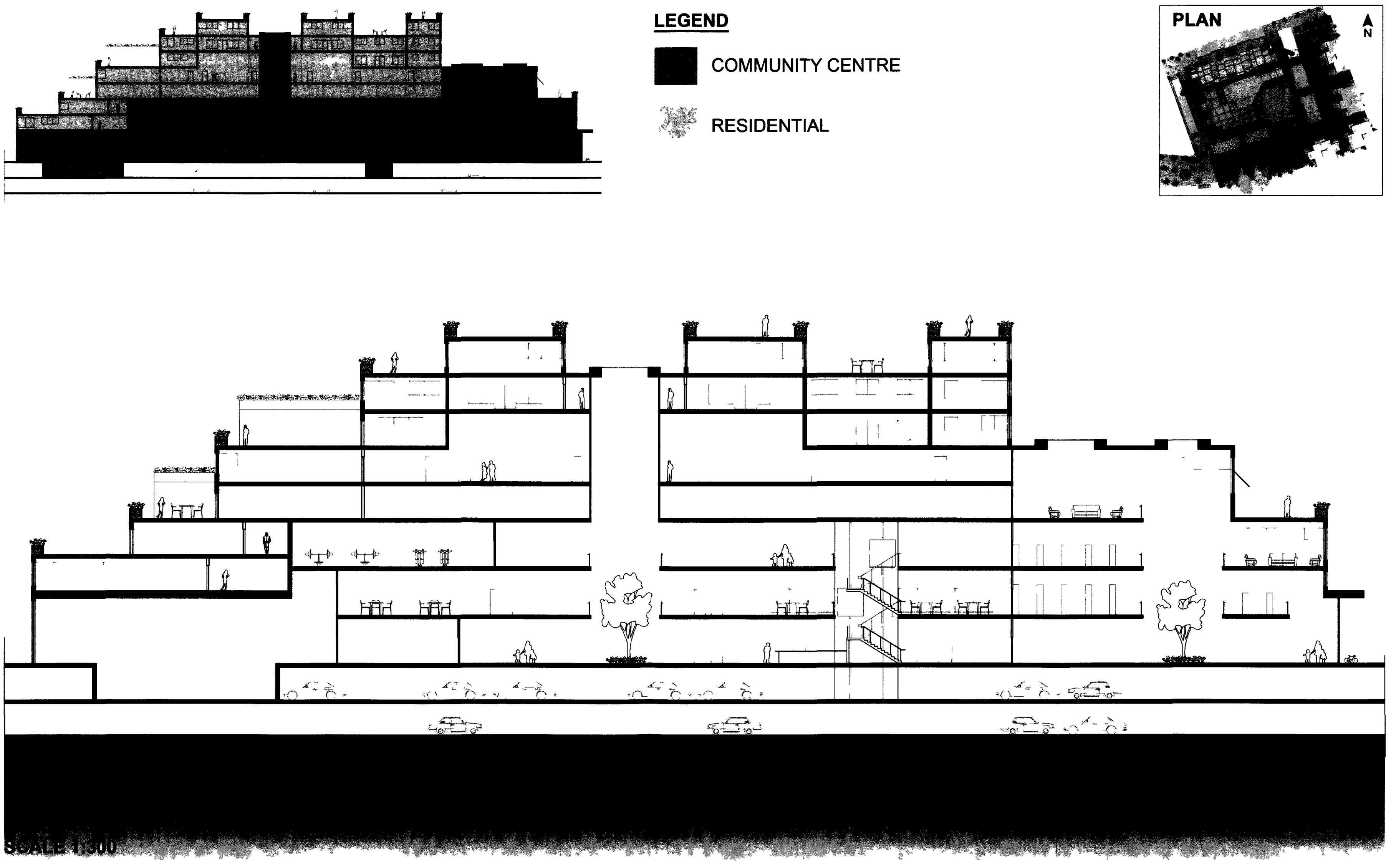


\section{STREET AND SIDEWALK}

The width of the sidewalk is important for social interaction to take place and especially important for children's play. Jacobs describes surveillance as the key dimension to successful urbanism; she believed that natural surveillance should be built into neighbourhoods and communities, what she called 'eyes on the street'. Urban structures in the proposed design allow people to focus on streets, by having buildings fronting public spaces promoting natural surveillance.

The automobile paths are narrow and have street parking to slow down traffic. The result is a street that is pleasant and safe to walk along. The wide sidewalks with trees for shade, along with buildings that hold the street edge create a pedestrian friendly environment. Wider sidewalks allow for areas of congregation, play, discussion, and for life and activity to spill out onto the streets for example sidewalk cafes, patios, kiosks and market spaces.

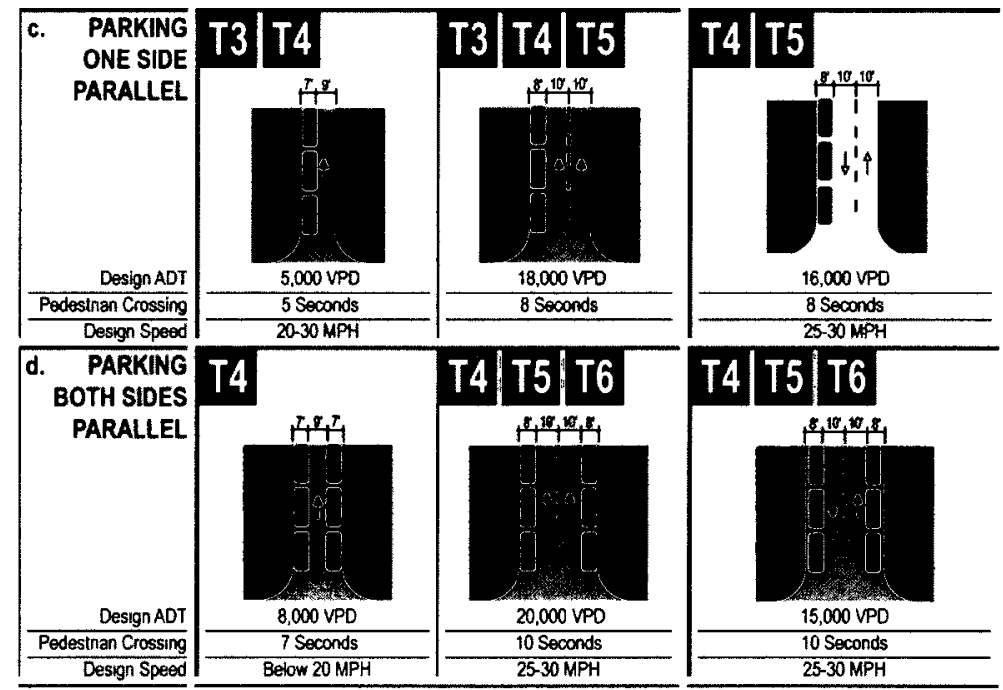

Figure 25: SmartCode Vehicle Lane and Parking Assembly 
Figure 26: Pedestrian Walkways and Street Views
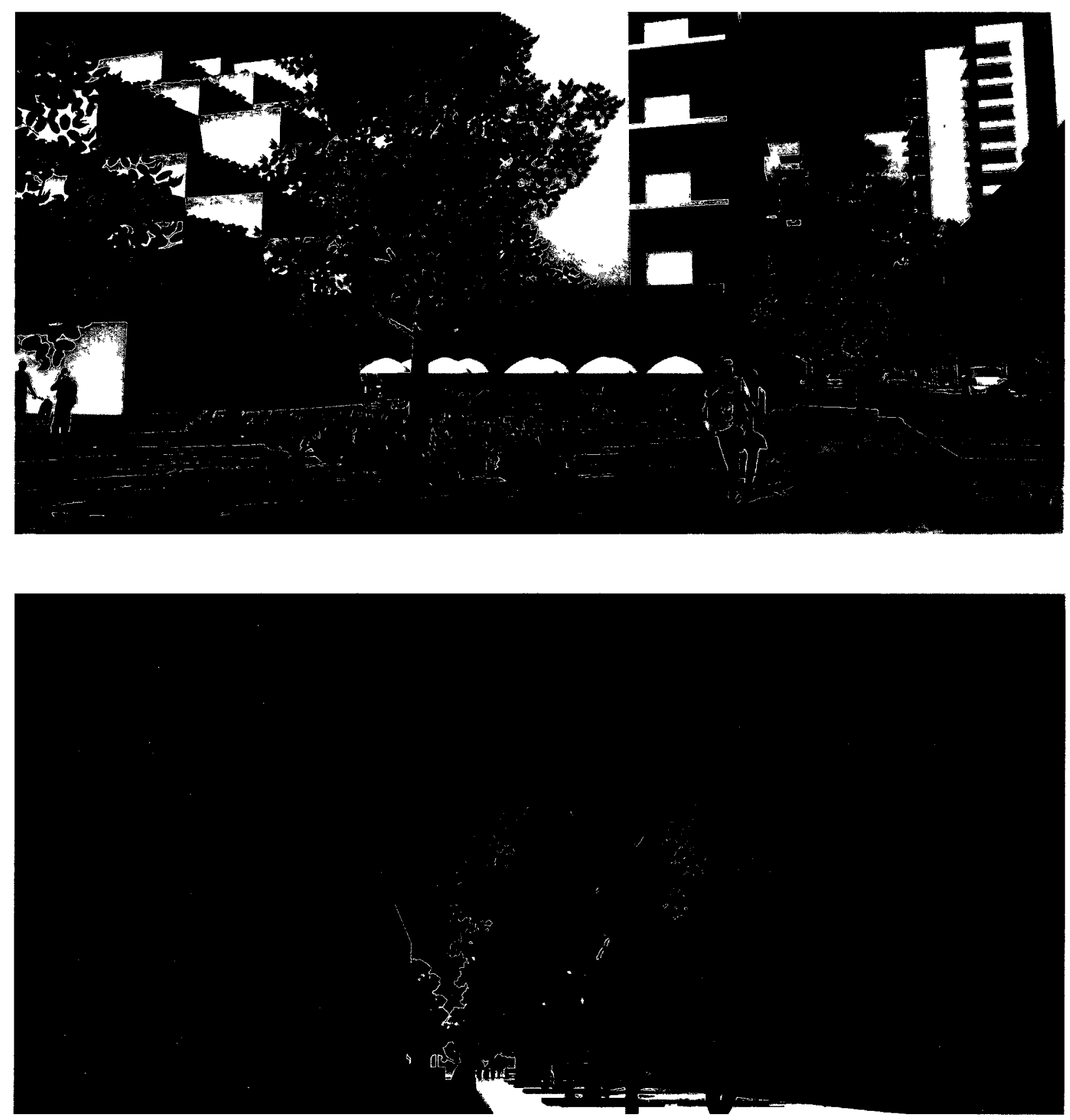

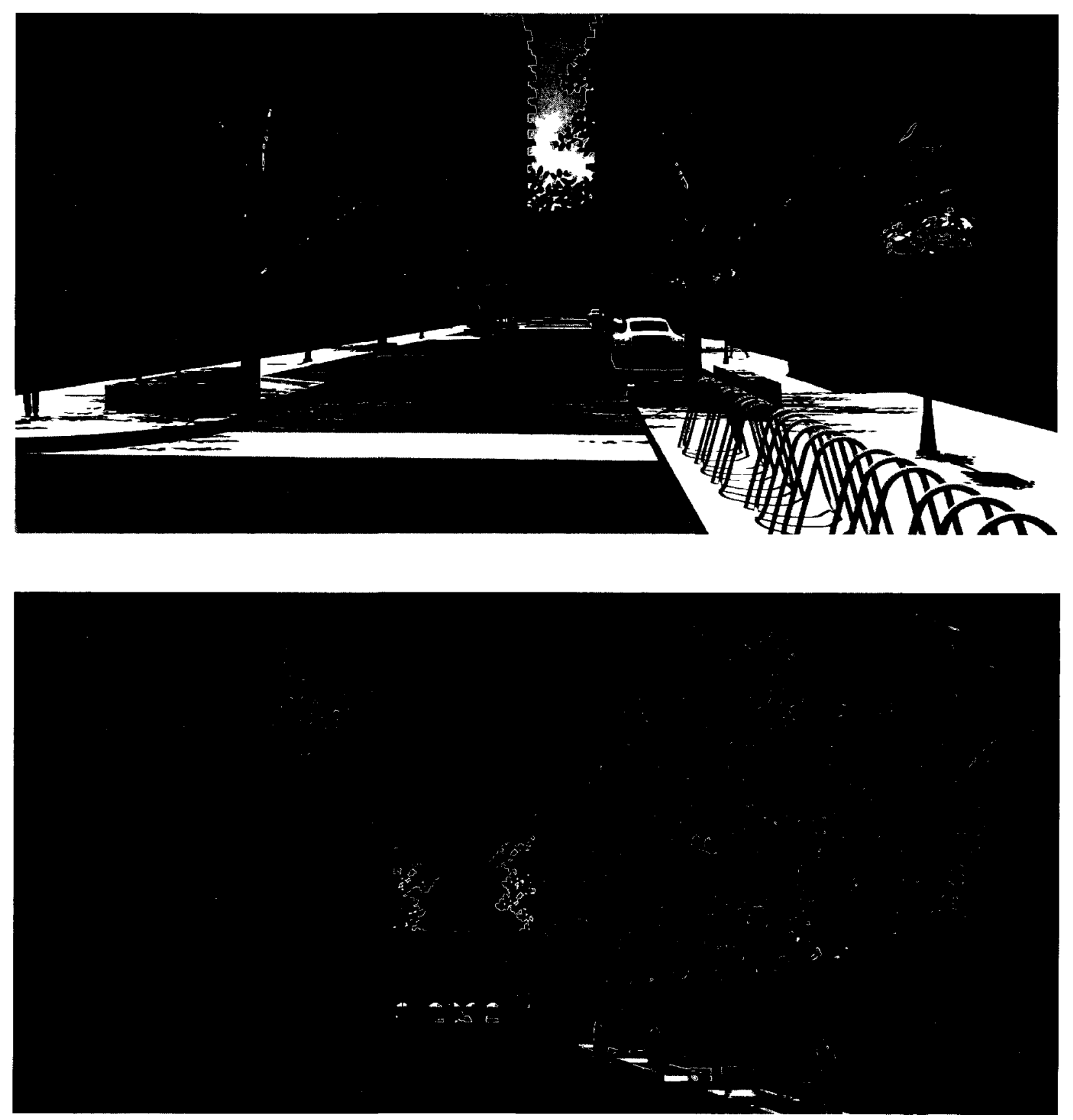


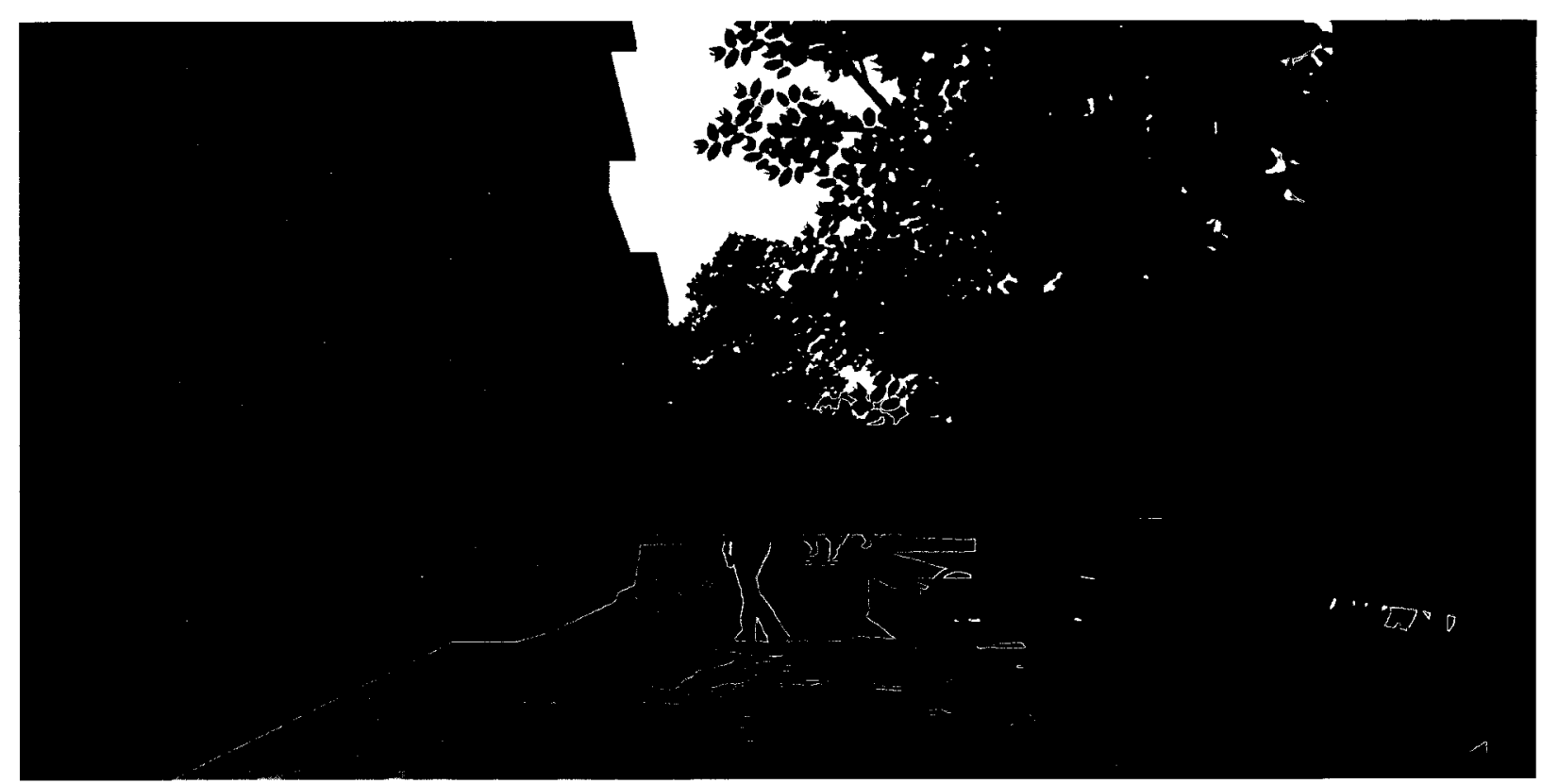




\section{PUBLIC SPACES}

The following vignettes show how public spaces can incorporate varied uses to create areas that can foster social interaction and create places for people sit, linger, watch and participate in the public realm. The central public space provides adequate room to accommodate the following: winter skating pavilion, farmers market, outdoor movies, local vendors and kiosks, shows, outdoor sports activities (yoga, Pilates, karate), etcetera.

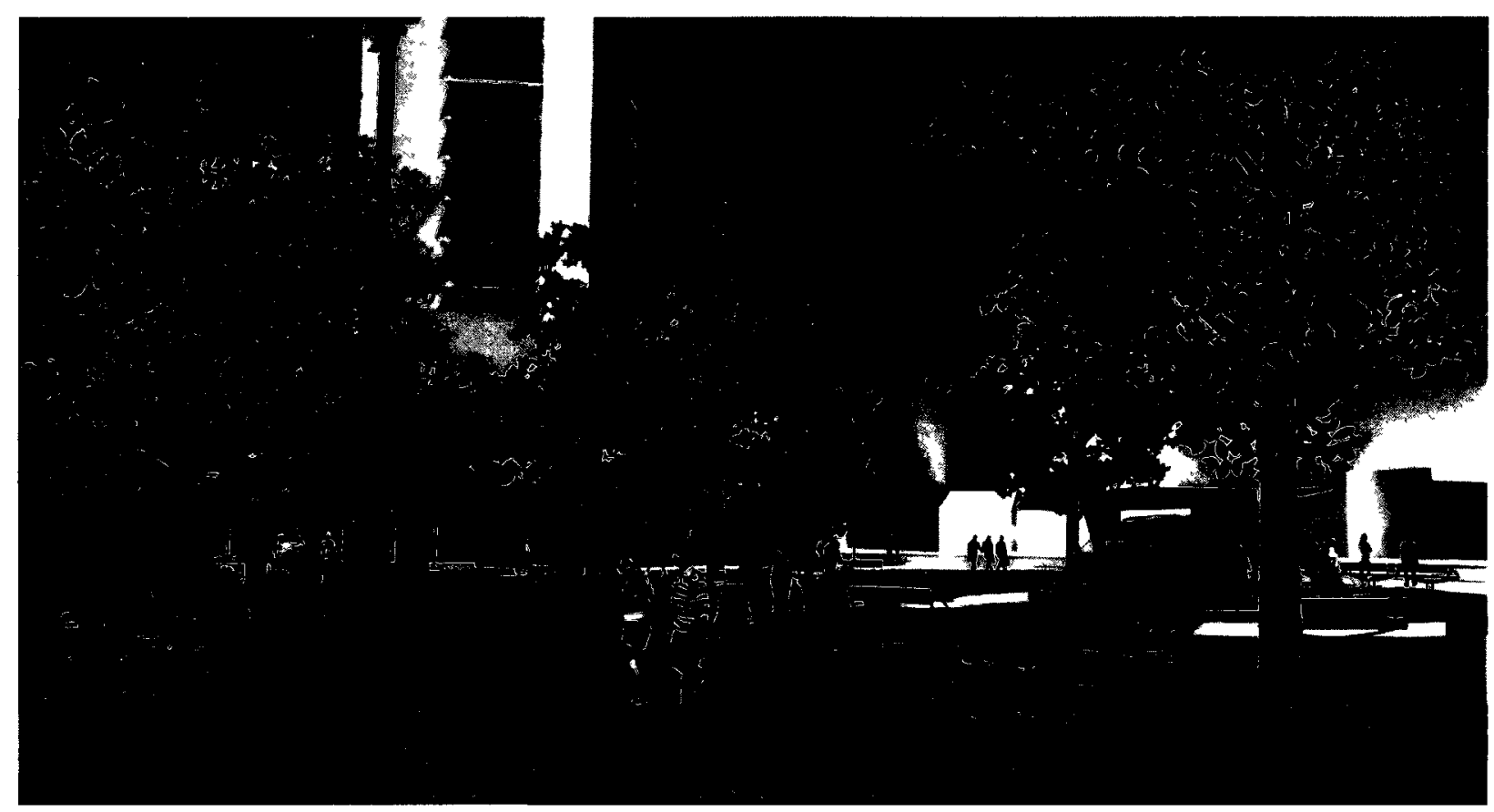

Figure 27: View of Park Bordering Sheppard Avenue East

The existing Parkette expands onto the proposed site and connects to the existing residential subdivision beyond through pedestrian path, and connects proposed site to main transit stop along Sheppard Avenue East. 


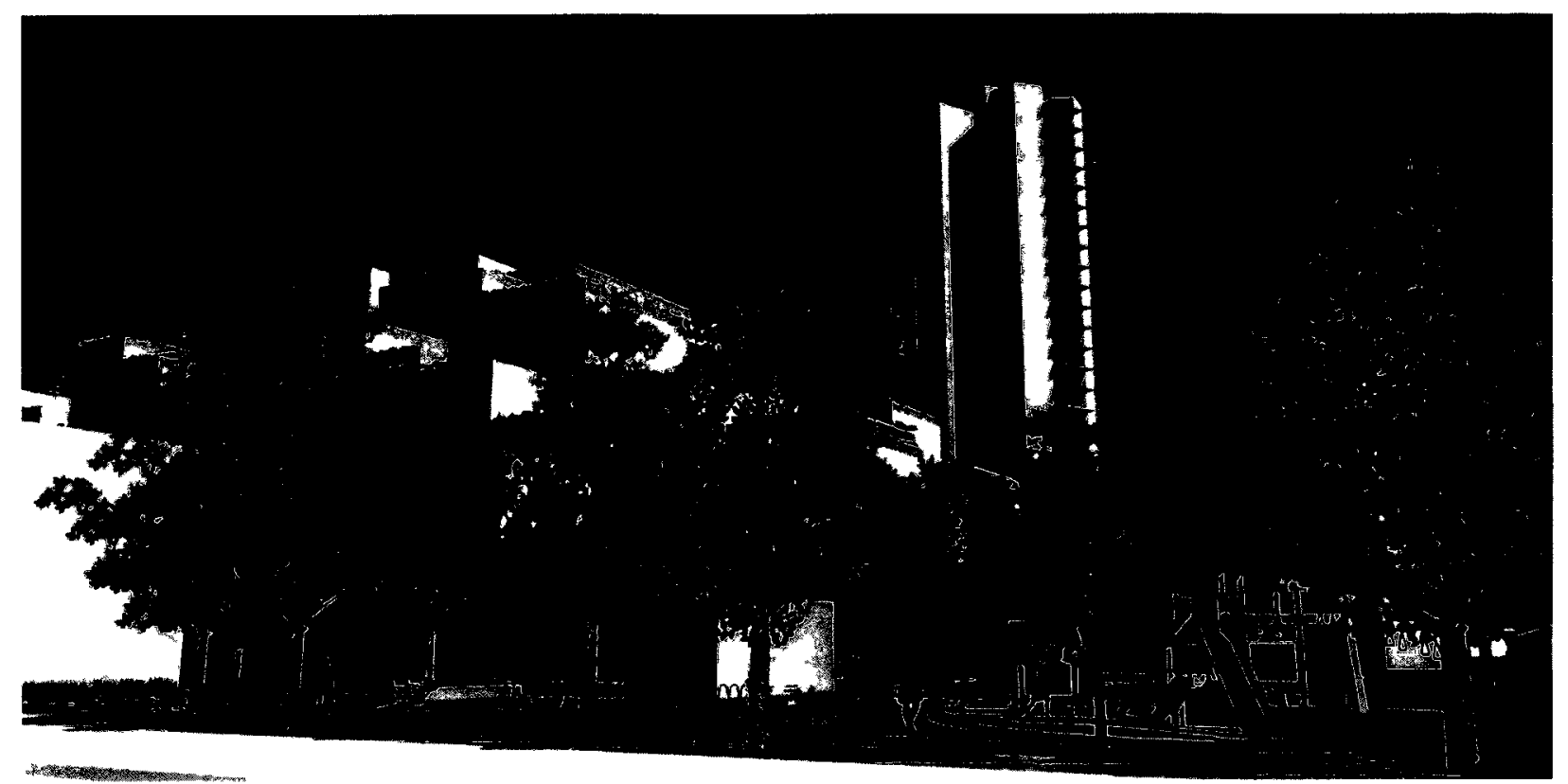

Figure 28: View of Park Entering from the North

Park next to community centre entrance and connected to the existing residential subdivision beyond.

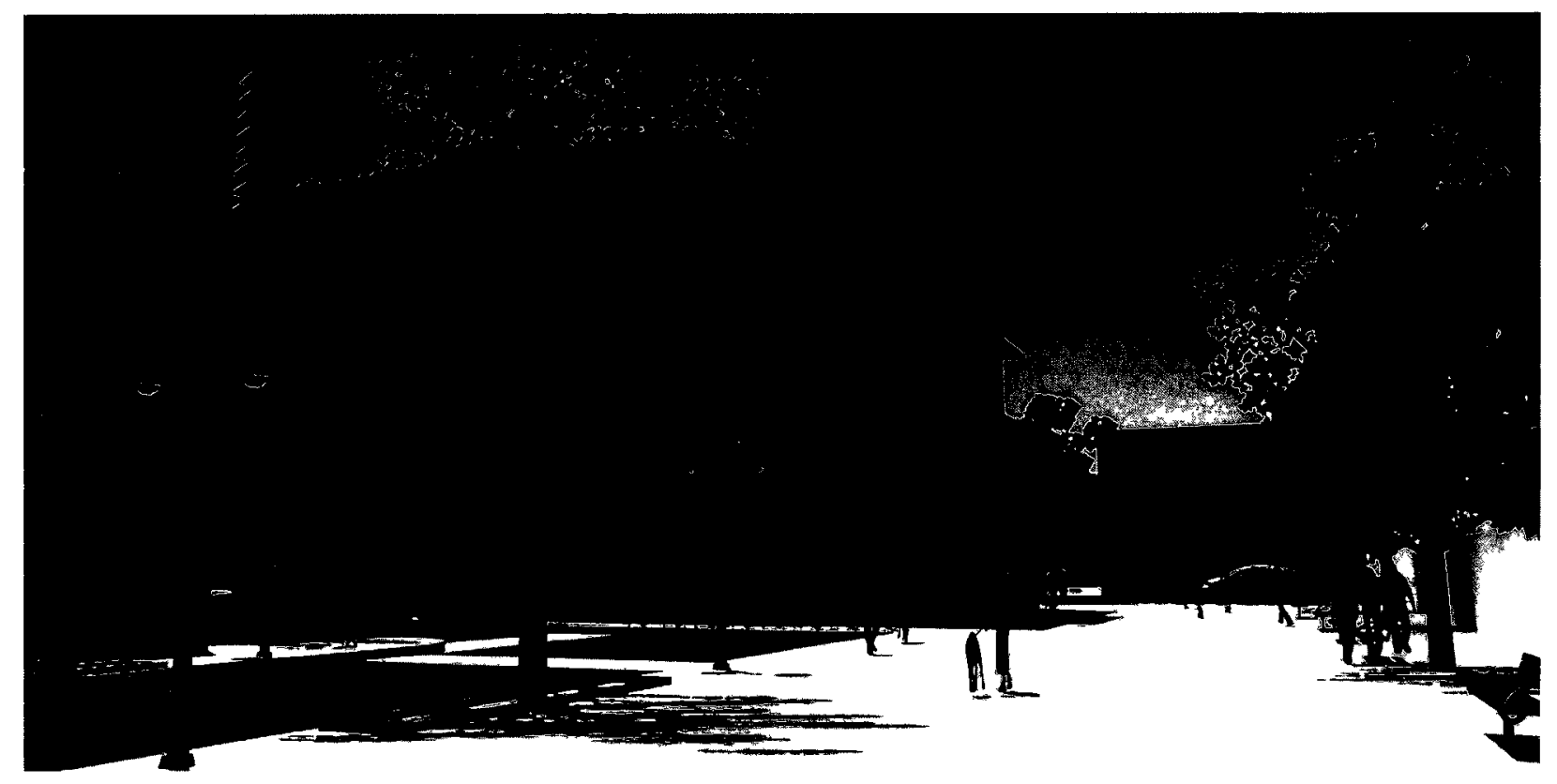

Figure 29: View of Green Space Connecting to Victoria Park Avenue 


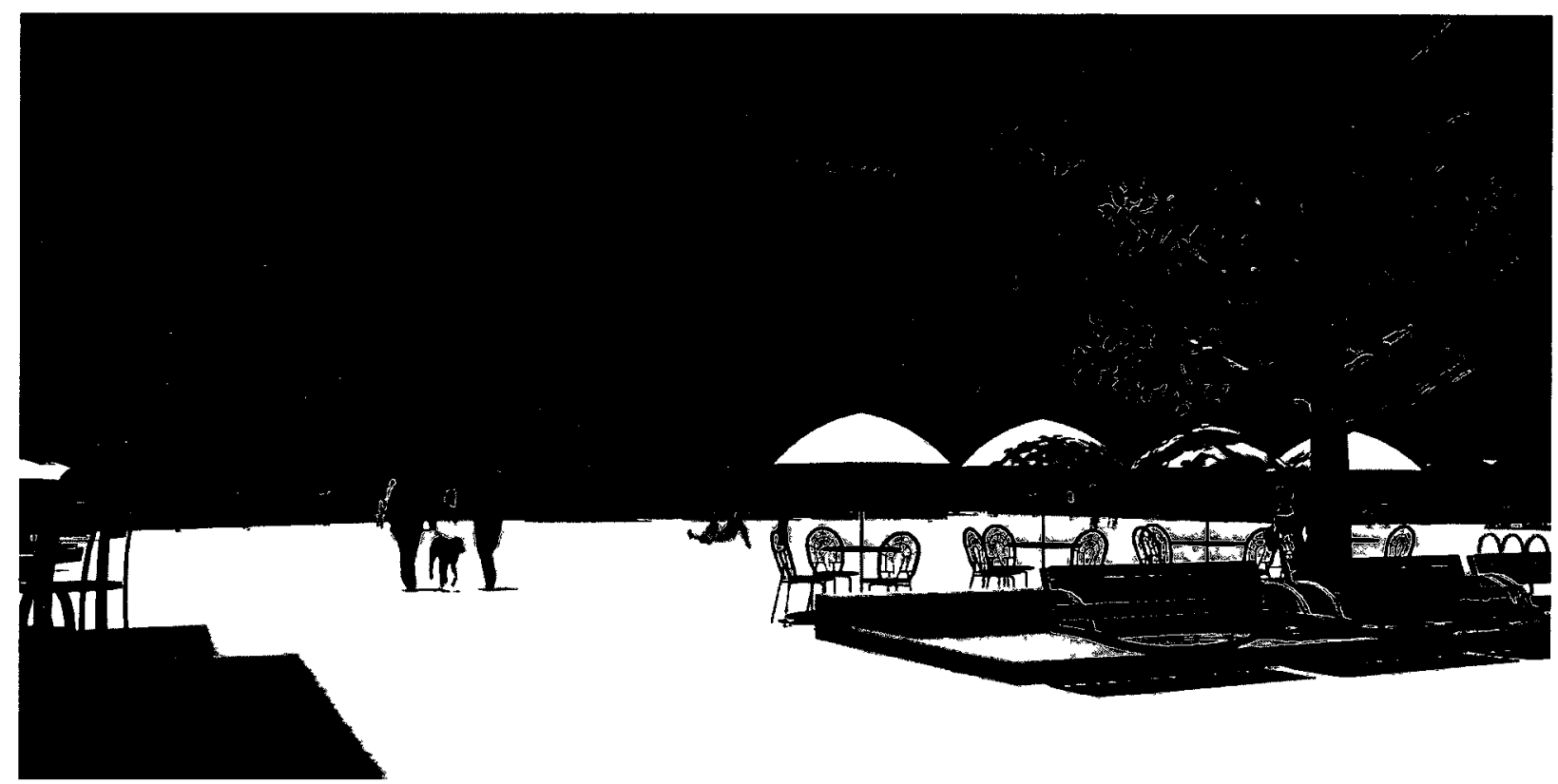

Figure 30: View of Central Public Space

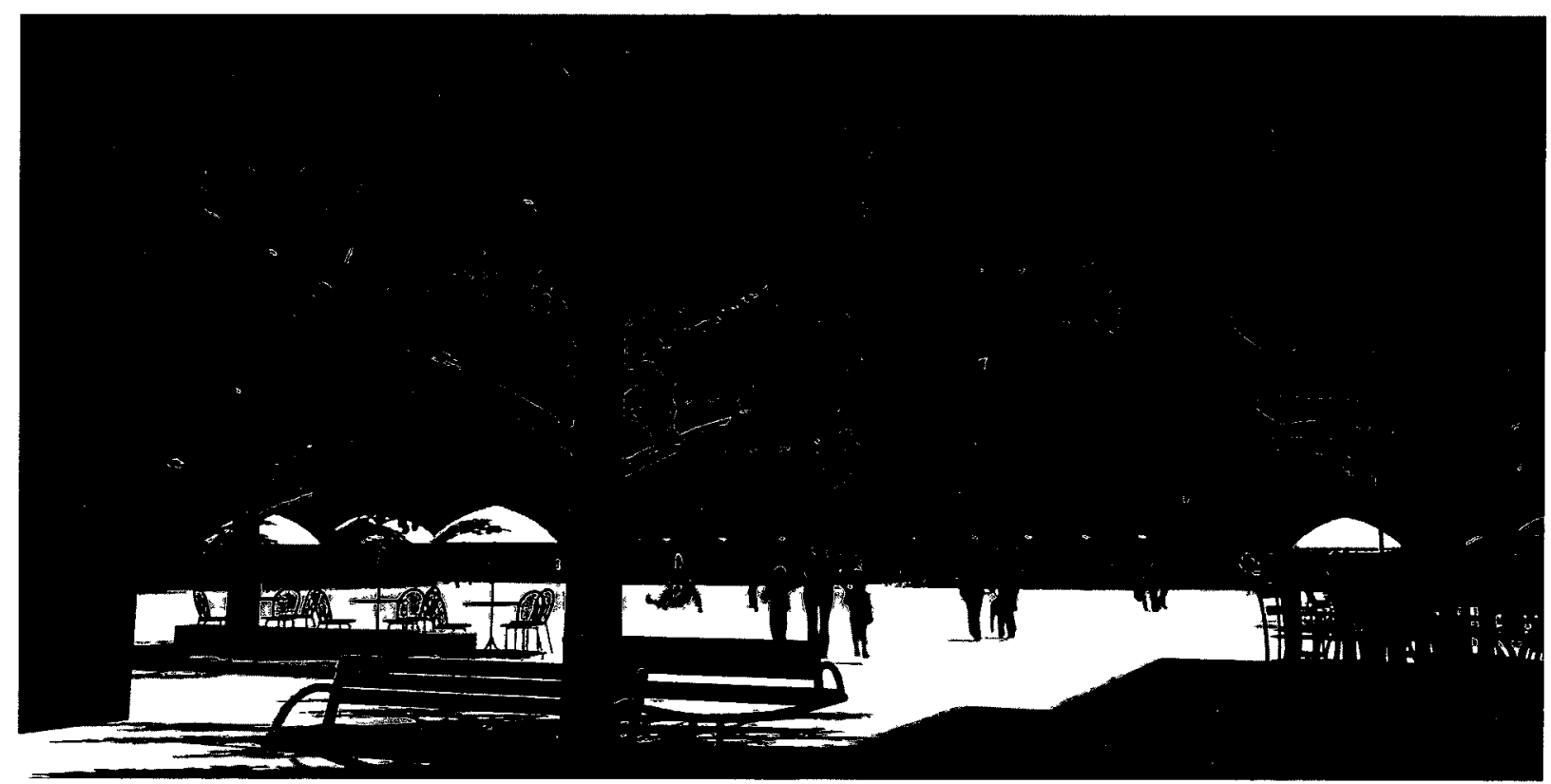

Figure 31: View Approaching Central Public Space by Pedestrian Street 


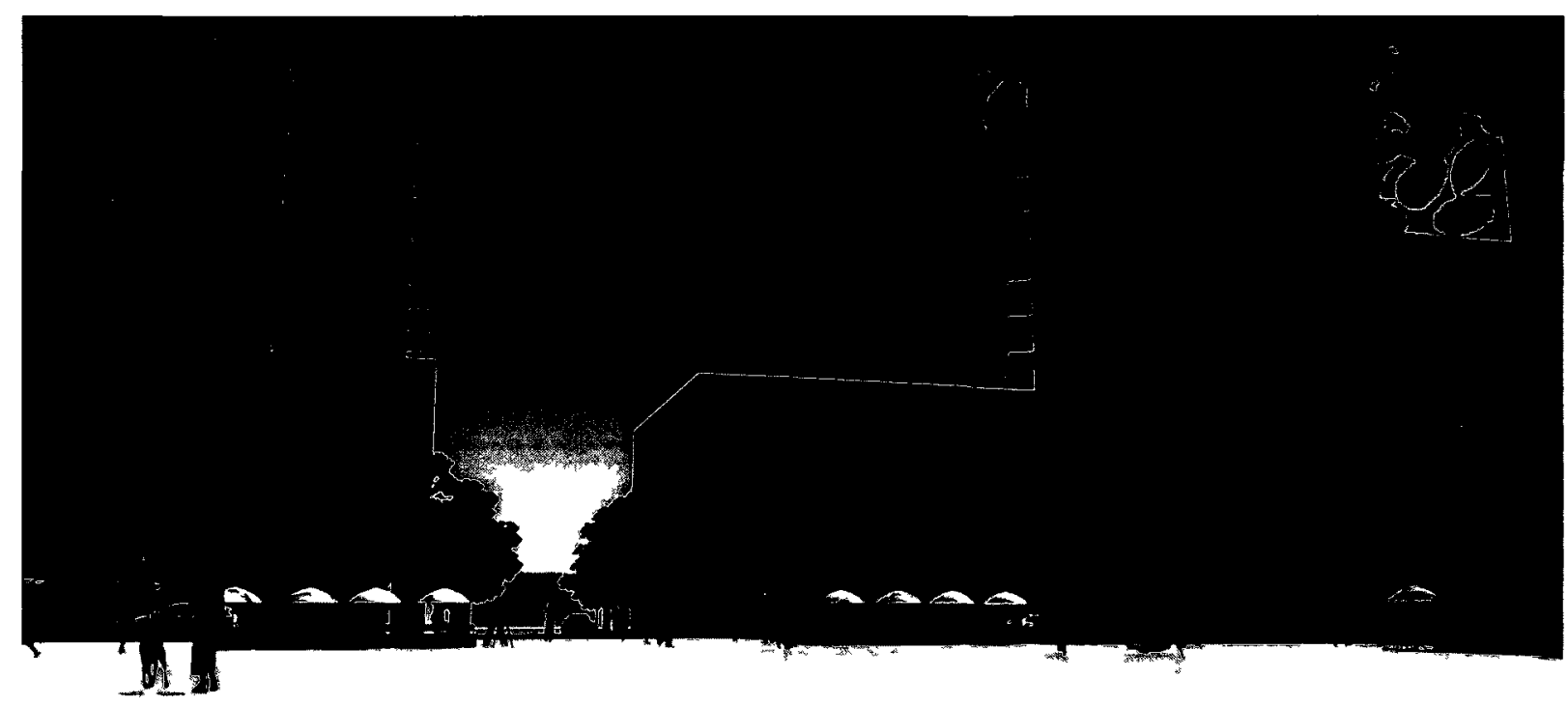

Figure 32: View of Central Public Space

\section{TRANSIT CONNECTIONS}

The following vignettes show the development and integration of transit stops into the design of the proposed project and surrounding community. By developing a node or centrum on a transit line, provides access for people to and from the site and increases the number of people who use public transit system as well, thereby enhancing the services efficiency and frequency. With the development of proposed plans of Sheppard Avenue East as a main transit corridor, access to the site and others like it on Sheppard Avenue East will only improve with time as above or below grade LRT lines are implemented. 


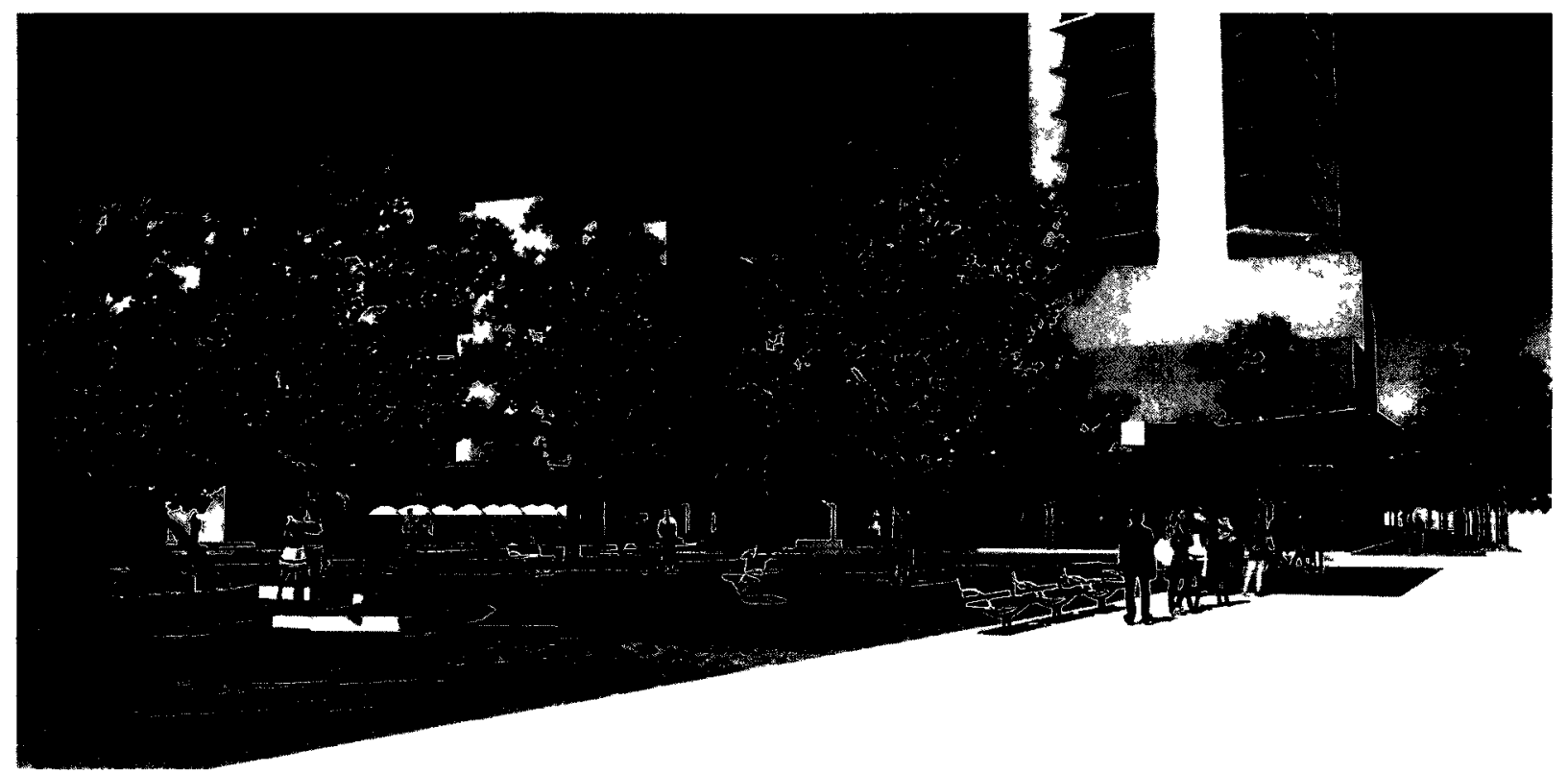

Figure 33: View of Transit Stop on Sheppard Avenue East

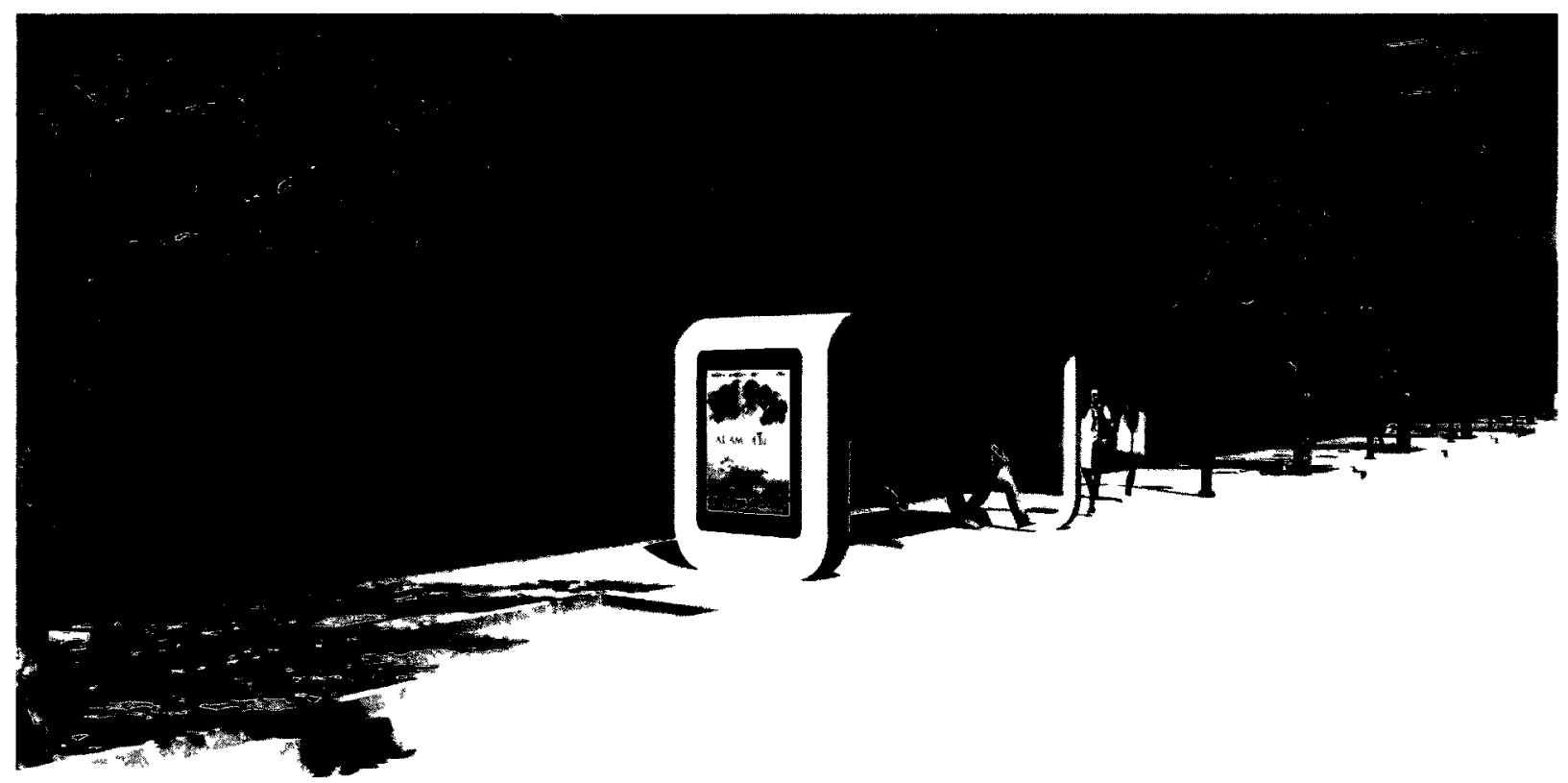

Figure 34: View of Transit Stop on Victoria Park Avenue 


\section{DENSITY AND OTHER STATISTICS}

\section{SITE: 35665 m sq OR 8.813 acres}

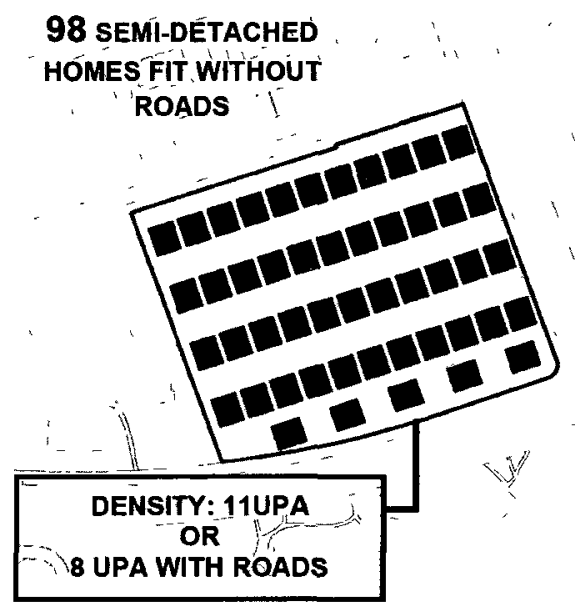

Residential:

UPA = units per acre

Average American suburb: 3-4 UPA

The average is 7-10 UPA in Toronto

\section{Residential: 663 Units $=75$ UPA}

- Includes: seniors residents, variation of suburban home, stacked maisonettes, townhouses, apartment flats above retail, and bachelor, 1-bedroom, and 2-bedroom units

Office area: $55,120 \mathrm{~m}^{2}$ or $593,309 \mathrm{ft}^{2}$

Community and recreation area: $18,753 \mathrm{~m}^{2}$ or $201,860 \mathrm{ft}^{2}$

Retail/commercial area: $24,445 \mathrm{~m}^{2}$ or $263,120 \mathrm{ft}^{2}$

Existing Building area: $96,835 \mathrm{ft}^{2}$

Number of street parking available: 50 spaces

Number of parking spaces needed:

Residential - 663 parking spaces (underground - one space per residential unit)

Office/Retail/Community Centre - 1027 (underground - as per shared office/retail factor of 1.2)

Although, in total 1690 parking spaces are required, as part of a method to think sustainably and towards looking at alternatives to driving such as public transit, walking, bicycling, and carpooling the goal should be to reduce the number of parking spaces as much as possible. Since the site is located on two transit corridors and integrated into surrounding neighbourhoods a logical stance can be taken to reduce the number of parking spaces on site. For example, reduce the 1027 required parking spaces by at least half. 


\section{JOB STATISTICS}

Standards:

Office -1 job/ $25 \mathrm{~m}^{2}\left(269 \mathrm{ft}^{2}\right)$

Retail - 1 job/ $110 \mathrm{~m}^{2}\left(1184 \mathrm{ft}^{2}\right)$
Proposed Site Job Statistics:

Office -2205 jobs

Commercial/Retail - 222 jobs

\section{NEW FORMULA FOR PROTOTYPICAL GREYFIELD REPURPOSING}

(RETAIL/COMMERCIAL (AMENITIES) + RESIDENTIAL + COMMUNITY/CULTURAL SERVICES + MEDICAL/OFFICE SPACE + SEPARATION OF CAR AND PEDESTRIAN PATH + PUBLIC SPACE + STREET FURNITURE + NATURE + TRANSIT CONNECTION) = FUTURE DEVELOPED SITES

\section{PROTOTYPICAL REPURPOSING FACTORS:}

By converting the square footage of each type of function into acreage and then dividing the number by the total site acreage creates factors. Any factor when multiplied by any given site area will give the amount of acreage needed for each function. By calculating the factors and targets based on the proposed site that attempted to push the limits on how much capacity a site can handle one provides a guideline or target numbers for repurposing any site into any configuration.

\section{Commercial/Retail: 0.6864}

Office: 1.5454

Cultural/Community: 0.5266

Target Residential Density: 63+ UPA

In comparison, the proposed project is well in line with the thoughts of Lewis Mumford and Jane Jacobs who both believed in the '60s that 70-100 people and jobs per acre was needed to produce an appropriate density and urban environment. Although half a century has gone by since their assumptions, their predictions are very appropriate and still relevant in contemporary and future development, mainly because for the past 50 years planners and developers have been working against these values of creating urbanity, and more for creating a sprawled suburban landscape. Furthermore, TOD suggests a minimum of 86 people and jobs per acre to reduce car trips and holds true if established within a one-kilometre radius with services, amenities, jobs and residents. As mentioned above in the statistical breakdown the 
proposed project has 75 UPA. Clarence Perry's neighbourhood unit had an estimated population of 5000 people per neighbourhood, equaling 40 people per acre or 10 UPA. In addition, Ebenezer Howard's Garden City with a population of 32,000 people on 5,000 acres looks at 30 persons per acre. Reston and Columbia both have similar densities of approximately 11 people per acre. Furthermore, Reston Town Centre only has 300 units within 140 acres in comparison to the proposed site that fit 663 units within 8.813 acres. Additionally, currently Shops at Don Mills has no residential component developed, however when the future 1300 residential condominiums units are constructed the site will be at 33.26 UPA. South Unionville Square a similar contemporary recent example is situated on a 7.5 -acre site that holds $300,000 \mathrm{ft}^{2}$ of retail space, $80,000 \mathrm{ft}^{2}$ of office space, 220 residential units equaling 51 UPA. LEED-ND requires that neighbourhood development must be greater than 10 or less or equal to 13 UPA. To receive the maximum points in LEED-ND new developments much have a residential density higher than 63 UPA. As such, present and future developments should meet LEED-ND's target as a minimum standard. By looking at the proposed project which easily surpassed LEED-ND's guidelines show that it is plausible and show the potentiality of how much capacity sites can handle and hold even with mixed-uses and allocated spaces for the public domain and parks. 


\section{Conclusion}

Since the turn of the $20^{\text {th }}$ century, people have continually criticized and created different interpretations and principles for how society can live better. However, more often than not these interpretations and models add to sprawl. In times of environmental concerns, rising oil prices, and people's interest in health and happiness, I believe that adding to the existing suburban landscape can begin to solve some of the issues facing society. The intention of the thesis was to propose a method of "fixing" or "repurposing" the existing suburbs. Implementing strategies of densification, intensification, mixing of both housing and uses, and incorporating public spaces on greyfield sites along main transit corridors help to repurpose suburbia.

Greyfield urban redevelopment can be the catalyst for community revitalization. Formally productive shopping centres, big box stores and strip malls are now underutilized; one time community assets are now suffering from disinvestment. These eyesores are symbols of a deeper-rooted pattern of haphazard development, and regardless of size, the property represents an opportunity to reinvigorate a community. By creating mixed-use and mixed demographic nodes, it provides the neighbourhood with the essential services it currently lacks. Greyfield sites are typically located at ideal locations that can make a difference for the surrounding neighbourhoods. Furthermore, in the process of repurposing greyfield sites or any future redevelopment in general, sustainability and environmental factors are of great importance. Designing future sites around natural systems like the sun, wind and methods of capturing rain and tackling storm water runoff takes sustainability a step further in the suburbs.

As described in the above chapters, suburban society is longing for inclusion and social relations; the monotony and segregation of the existing environment has led to the dehumanization of people. The thesis proposed techniques and strategies to bring and build back the missing public domain and social interaction that is so crucial to the wellbeing of inhabitants. By concentrating new development within the existing suburbs, along major transit corridors, it is creating alternatives to the automobile. Transit-oriented developments integrate a diverse range of demographics and lifestyles. The thesis project illustrated the potential at both the micro and macro level. On the micro level, prototypical nodes have the ability to complete neighbourhoods. On a macro level, the nodes connected and linked together through public transit begin to create the neighbourhood efficiency on a greater scale, first in districts, than towns and cities. 
The thesis proposed: a transit-oriented, dense, mixed-use neighbourhood. With major changes in demographics and the greater awareness of environmental and health issues, projects like the one proposed will increasingly gain momentum and popularity in Canada and the United States. Although not everyone is ready for a transformation in thinking and lifestyle, a significant percentage of people are ready for positive change. Only by beginning to reshape the built environment will the natural shift in mentality of people begin to take effect. As Winston Churchill has said "We shape our buildings; thereafter they shape us." As present and future architects, by teaming up with planners and the populace we have the ability to reshape cities.

In reality, towns and cities are meant for people - for people to interact with each other, with their surroundings, and the environment. Aristotle describes civility as the art of living together well. For some time now, we have moved away from these ideas by making the automobile the focus from which we shape everything. Knowing that the way we grow, as well as how, and where, has a profound effect on the world, it is hard to imagine continuing on this path of destruction and disillusion. Mishima once said "to know and not to act is ultimately not to know." Moving towards the future it is time to bring back human scale. The repurposing of the suburbs will be the big architectural project of the $21^{\text {st }}$ century. 


\section{FUTURE WORK}

The best cities in the world did not become so over night; cities achieve success with time. In relation to civilization's oldest cities, the suburbs are a work in progress. The idealized promise of the North American dream is still in reach. By looking at the first suburban developments of a given city, shows the potential of how the most recent suburbs can urbanize and evolve with time. In Toronto, the first suburbs were streetcar suburbs; they were not only vibrant extensions of downtown today, but are popular places where people work, live, walk, eat, and linger. Streetcar suburbs like the Annex, the Beaches, Danforth, Lesleyville, Little Italy, and St. Clair have transformed into mixed, dense communities. Although they have a different form, with shorter blocks and gridded plans, there is no reason why the curvy roads and cul-desacs of postwar suburbs cannot also develop to become urban in character and quality - albeit in they own way.

The Victoria Park and Sheppard development described above is Phase 2 in my speculative three-phase plan to repurpose the suburbs. Phase 1 was the evolution of the suburbs to its current state of disrepair. Phase 2 focuses on society's next step - the repurposing of underdeveloped land (greyfield sites) within the suburbs, representing capacity along corridors that can fill in the missing pieces for the surrounding community. Phase 2 proposes the creation of prototypical nodes that not only promote efficiency and connectivity at the neighbourhood scale, but also can transform the suburbs into a condensed, intensified, and repurposed form. Phase 2 and 3 will not be possible without a change in municipal zoning regulations.

Phase 3 would address what I would call the "Backyard Condition." Phase 3 is beyond the scope of this thesis; it tackles the issue of the inward facing single-family homes with backyards facing main streets. Phase 3 allows for further development along corridors such as Sheppard Avenue by removing the backyard fences and adding new uses that face the main street. Homes that turn their backs to streets create dead spaces, and discourage people from walking. Dead spaces detract from pedestrian quality because there is nothing for the passerby to look at. "The Backyard Condition" can provide integrated amenities within the local neighbourhood. Such a plan of action would help further transform the suburbs into wellrounded, sustainable $21^{\text {st }}$ century neighbourhoods. 


\section{Appendix}

The following appendix displays the presentation slides from the thesis defense. 


\section{RE-PURPOSE}

- To reuse for a different purpose, on a long-term basis; To alter and to make more suited for a different purpose isourte en wiktonary org/wikl/repurpose)

- Taking a thing or a material and using it for a purpose not originally intended. [5ourcer www lohas.ram/glossary htmm!)

- To take what may be otherwise a waste item and use it for another purpose (source stigreencontractors com/inoicx php)
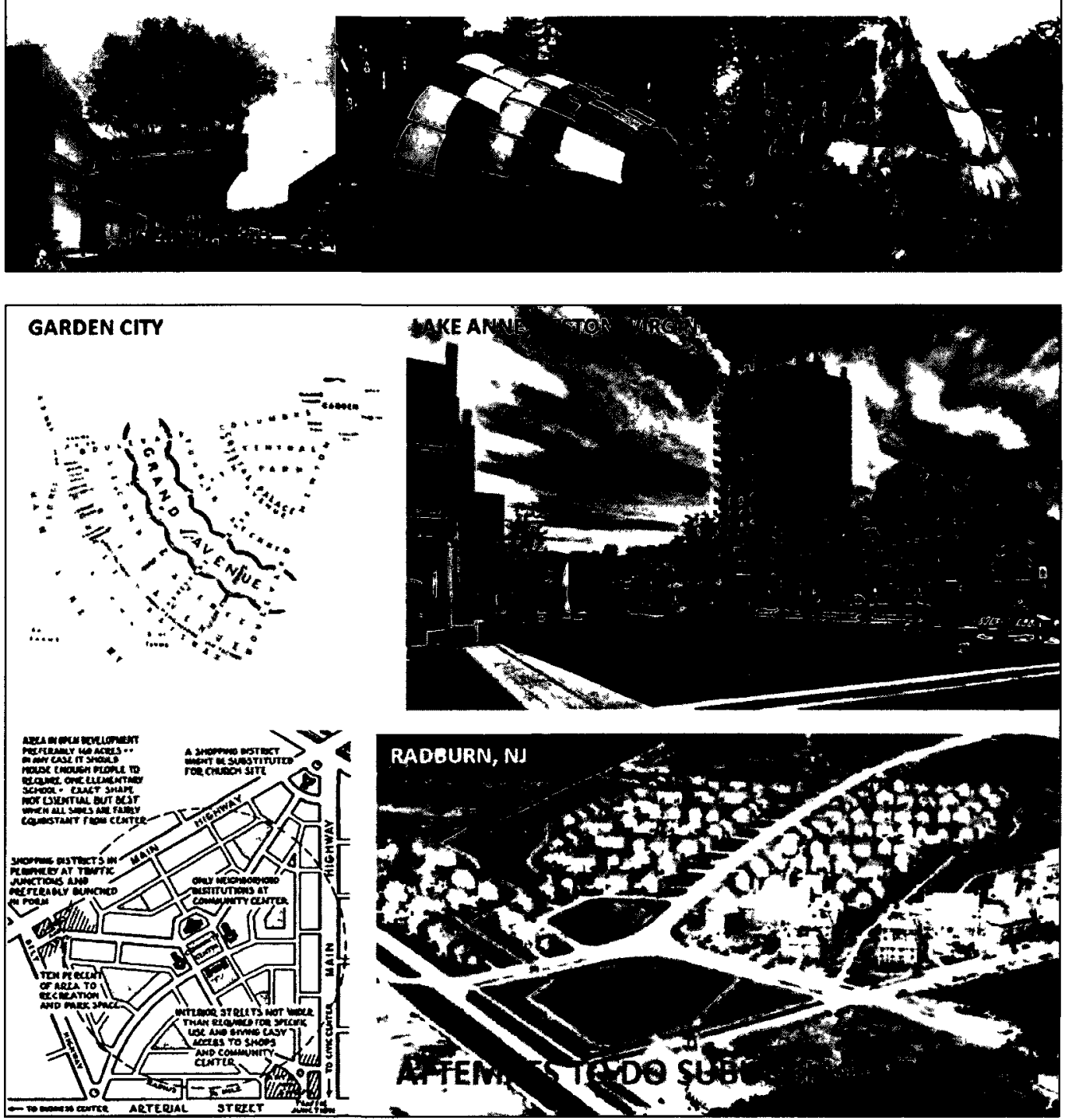

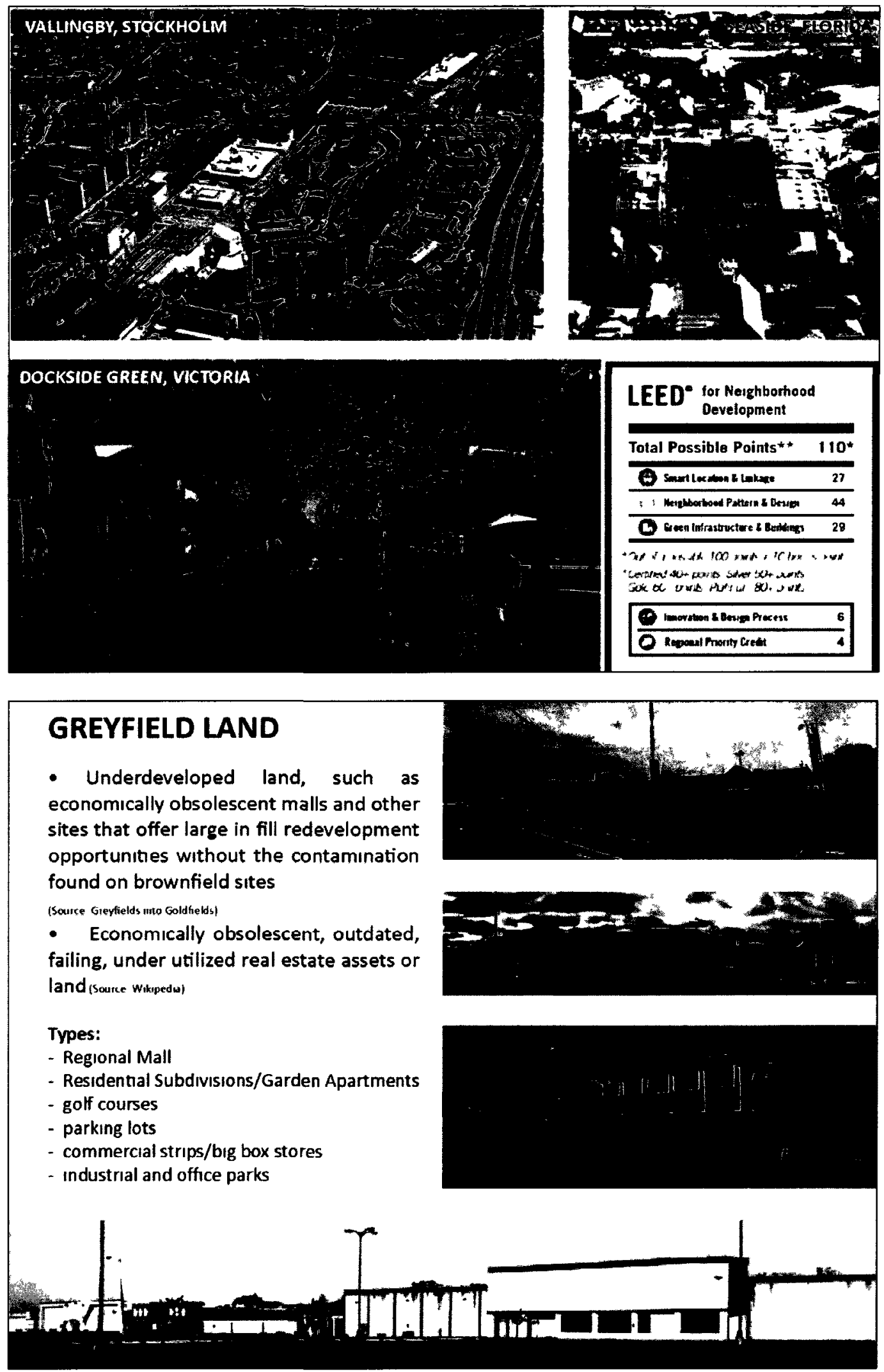

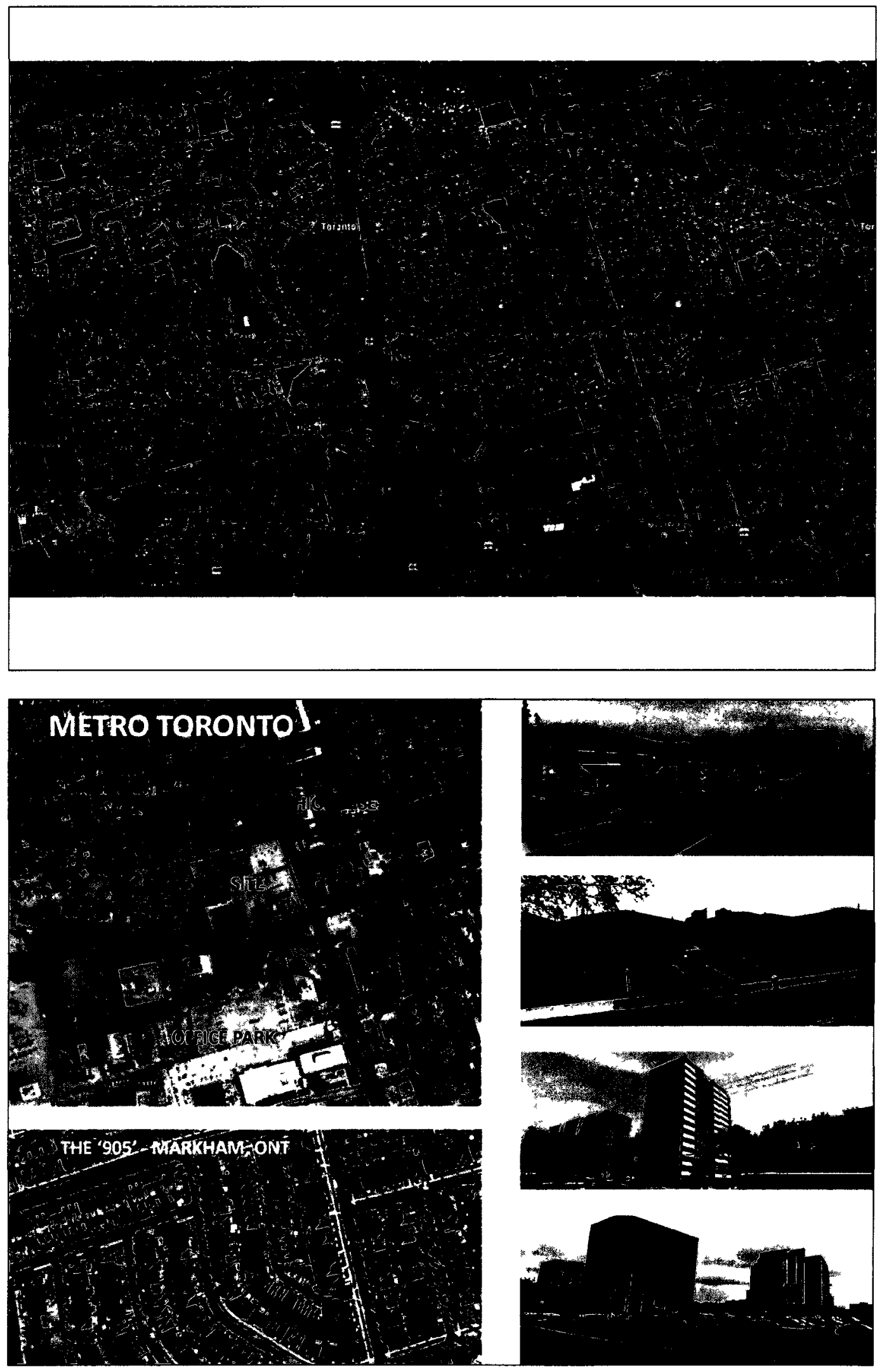


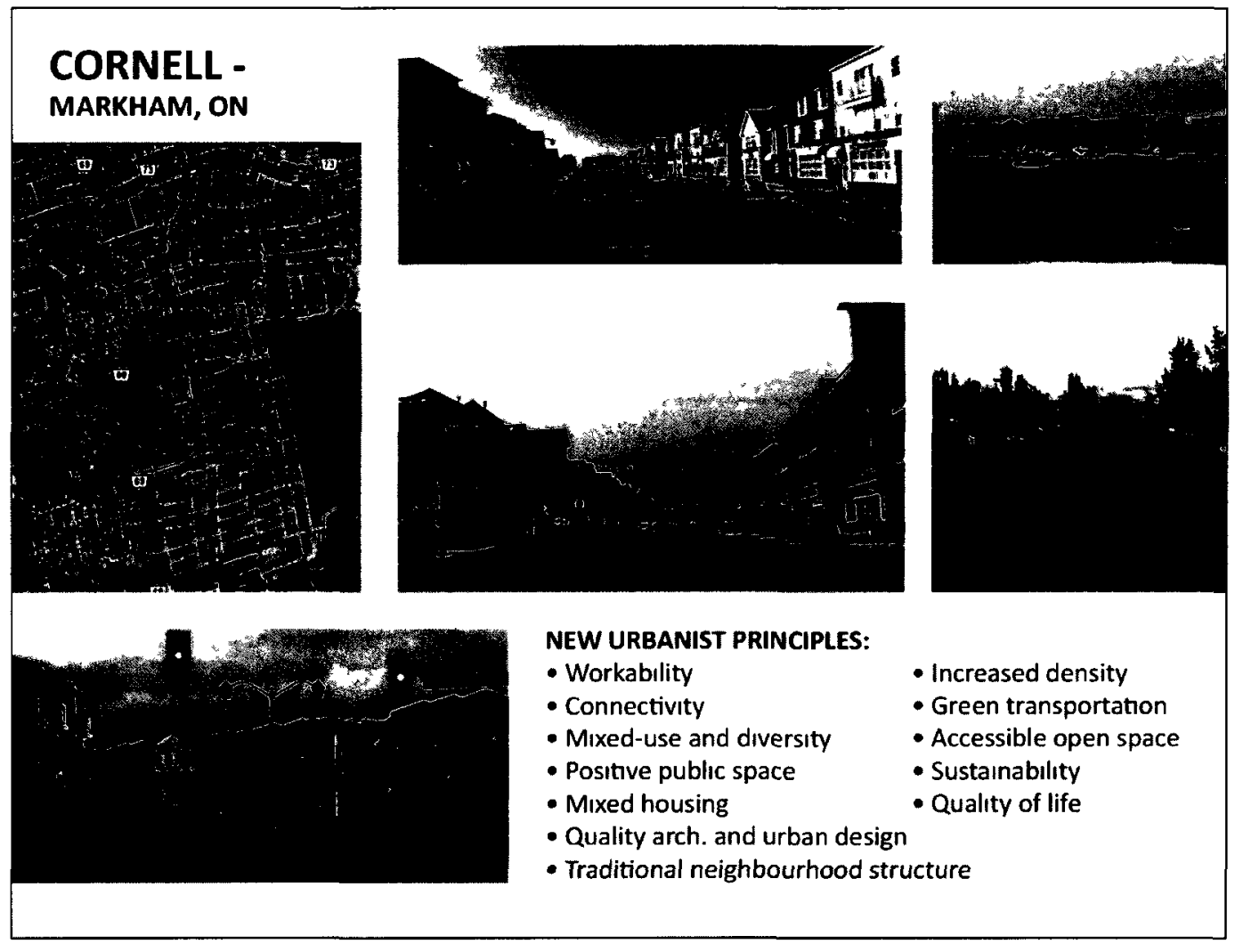

\section{RESTON TOWN CENTRE - RESTON, VIRGINIA}

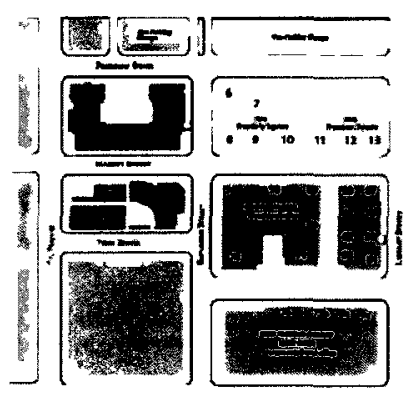

SITE: 140 ACRES

RETAIL: $372,378 \mathrm{ft}^{2}$

OFFICE: $2,100,000 \mathrm{ft}^{2}$

PARKING SPACES: 7,630

RESIDENTIAL: 300 UNITS
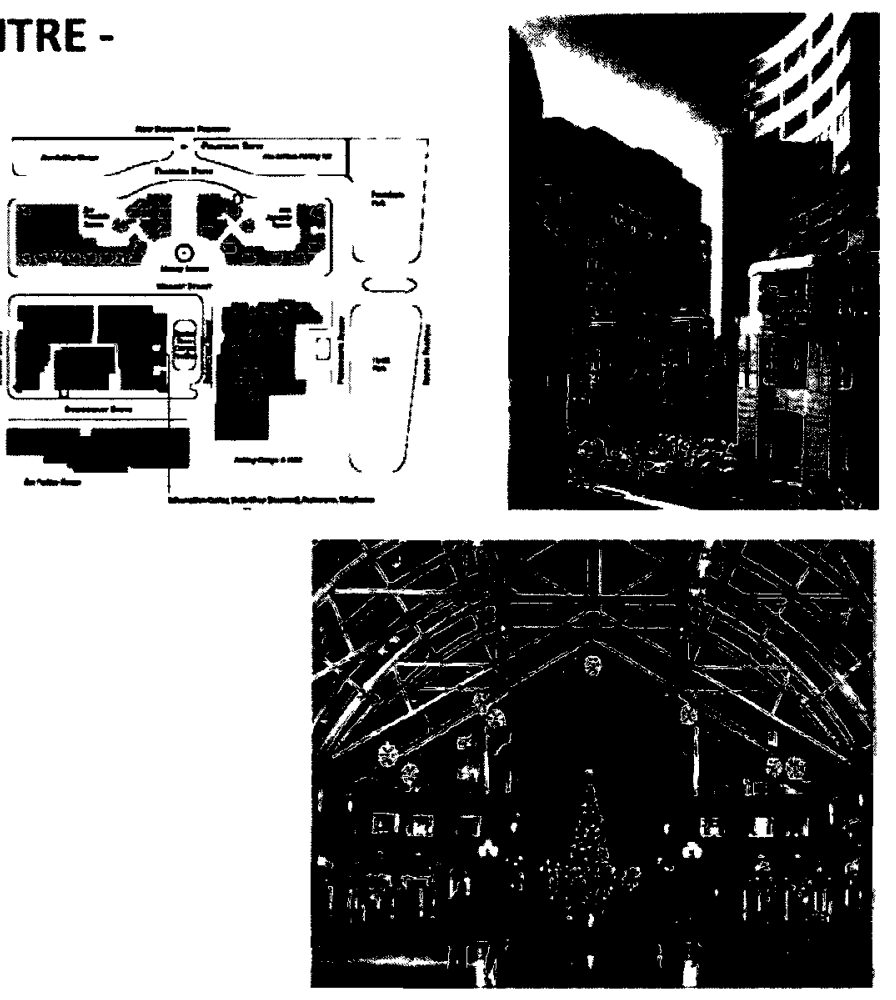


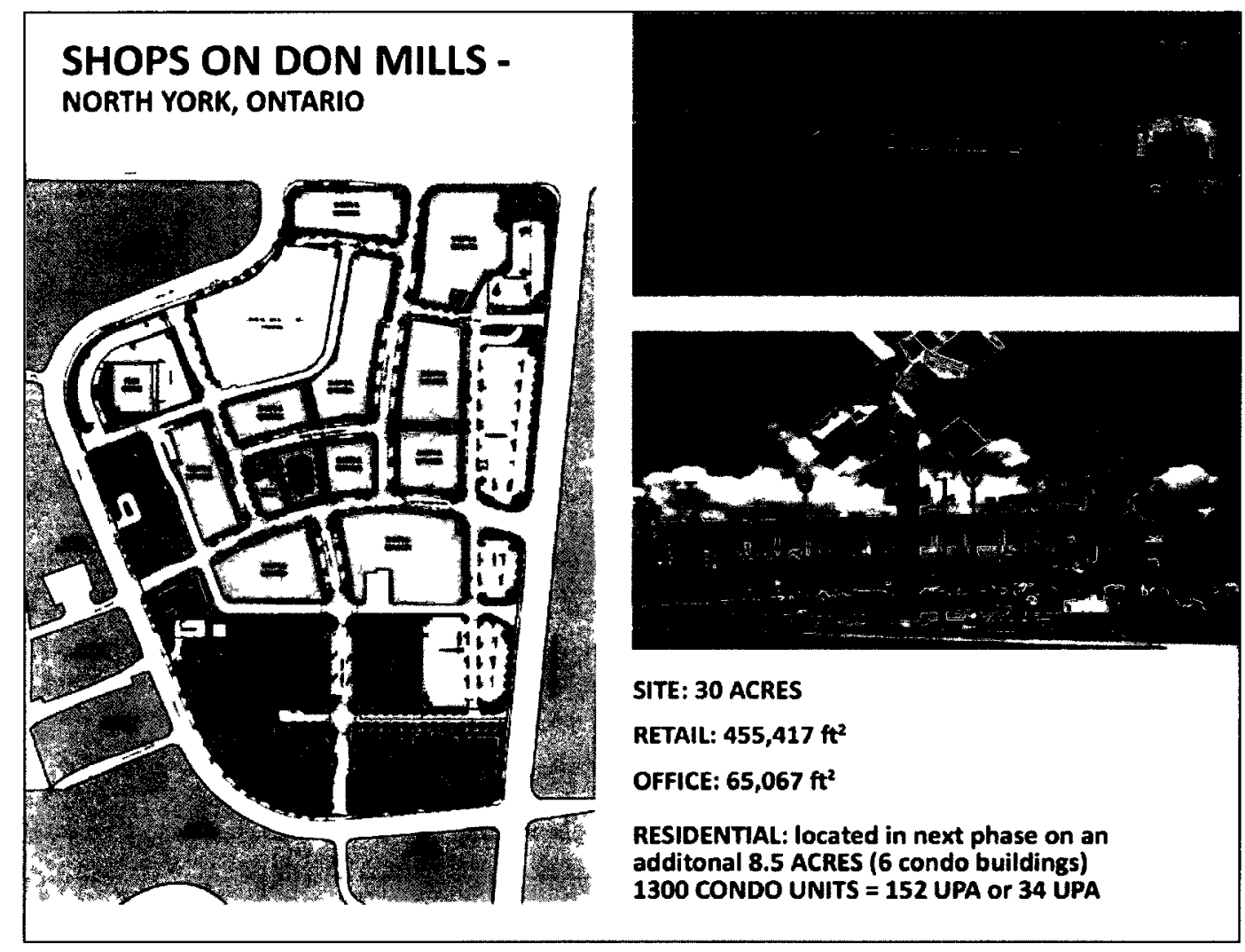

\section{SOUTH UNIONVILLE SQUARE -} MARKHAM, ON

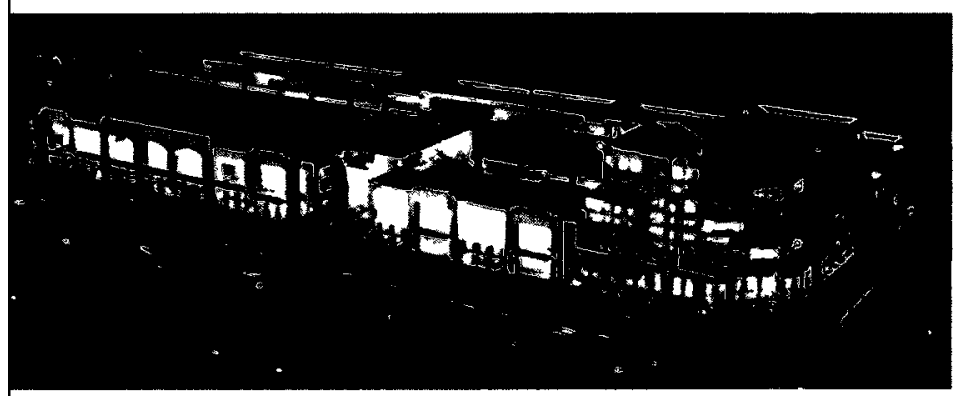

SITE: 7.5 ACRES

RETAIL: $300,000 \mathrm{ft}^{2}$

OFFICE: $80,000 \mathrm{ft}^{2}$

RESIDENTIAL: 11-STOREY

220 SUITES $=51$ UPA

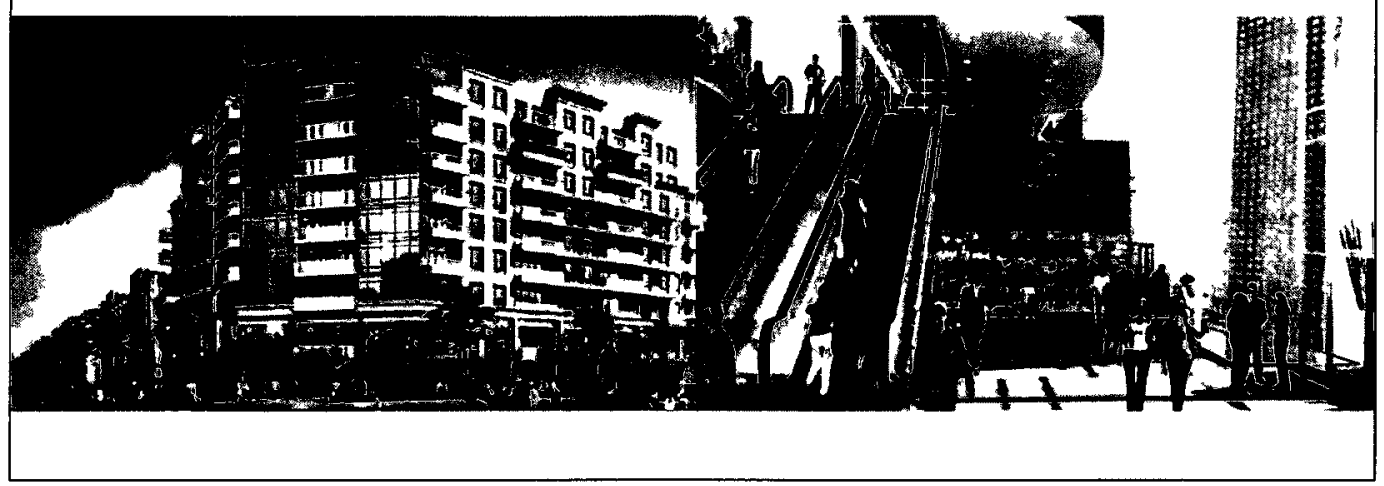




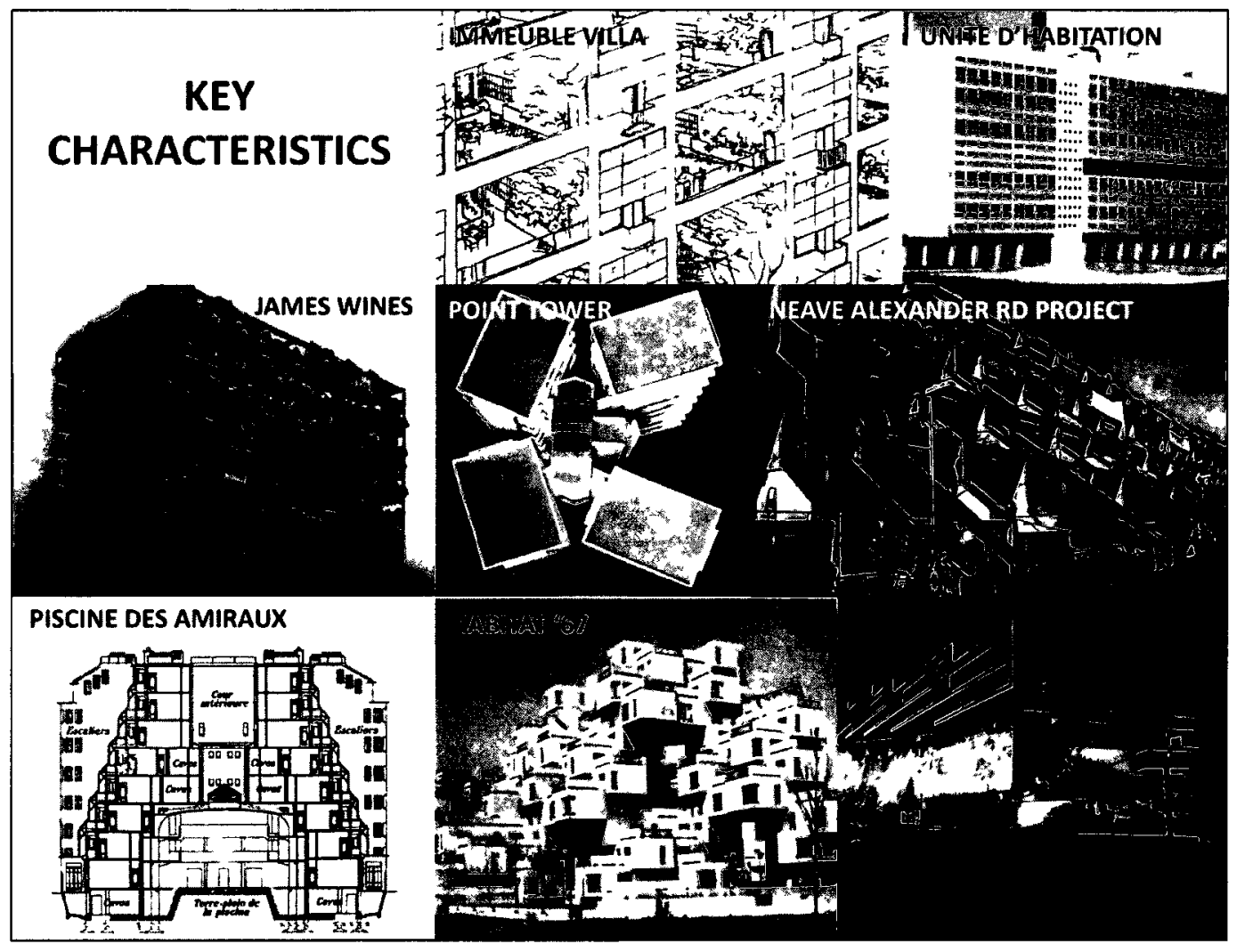

\section{PROJECT SITE INVESTIGATION}

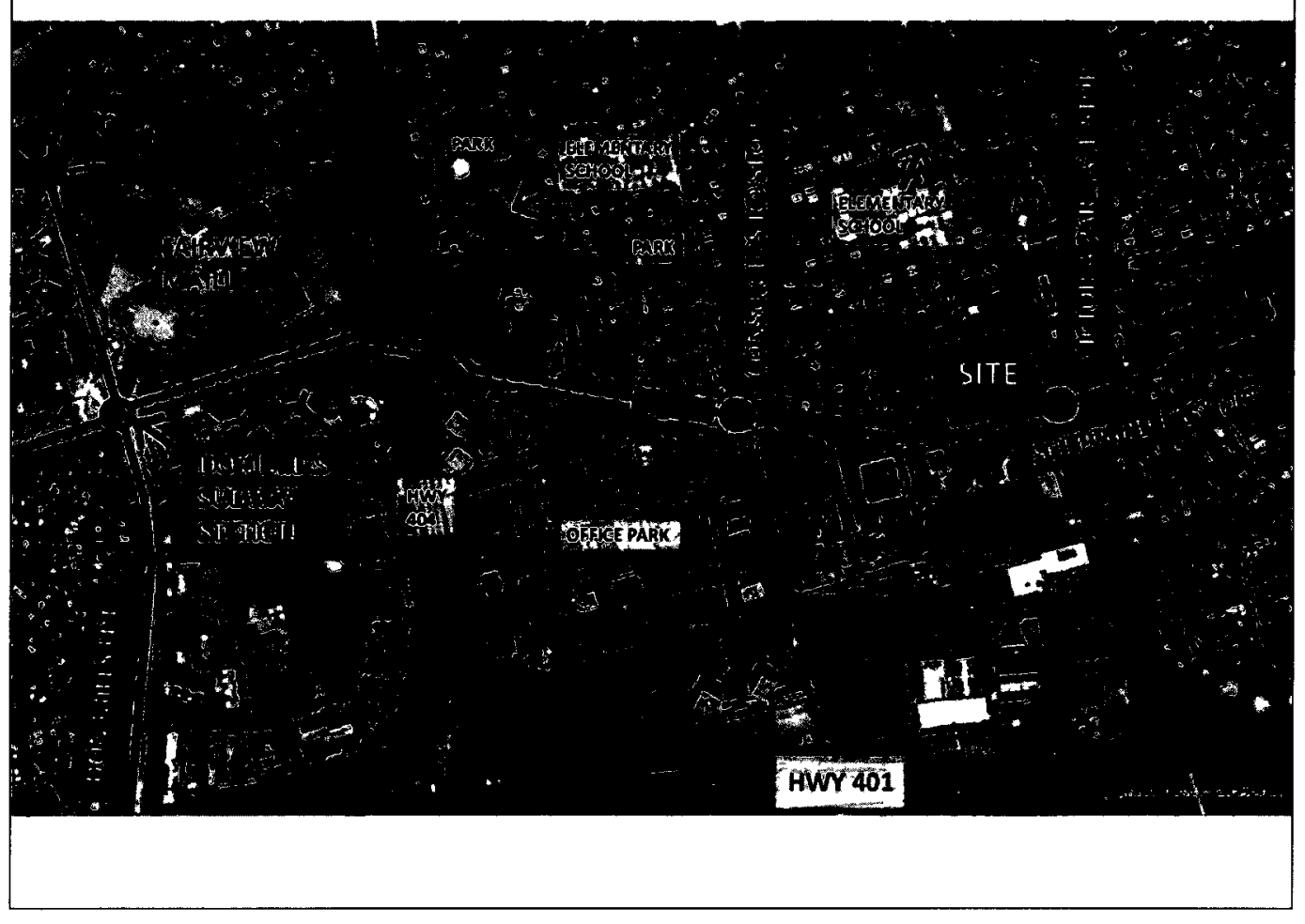




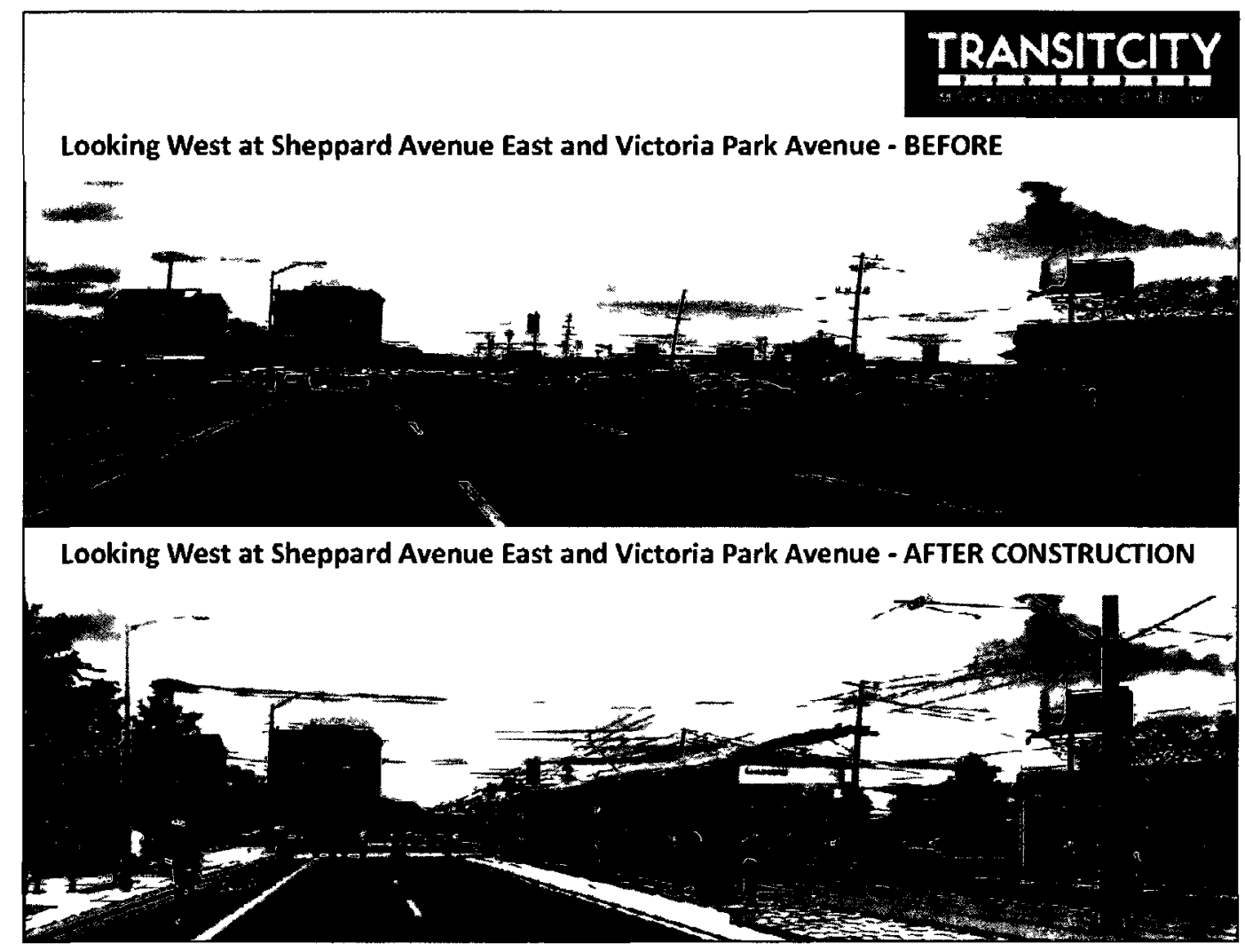

Compact mixed-use nodes reduce journey requirements and create lively sustainable neighbourhoods

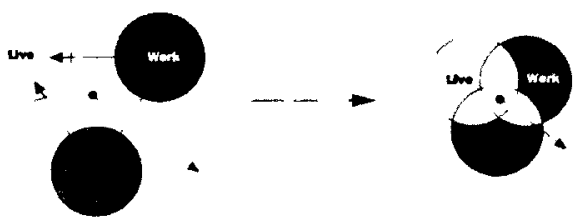

Compact nodes linked by mass-transit systems can be arranged in response to local constraints

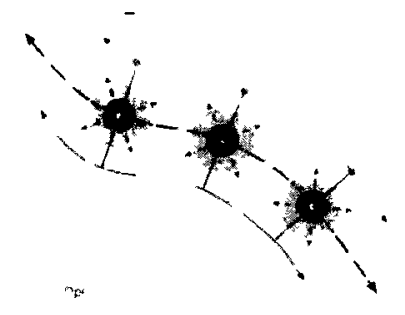



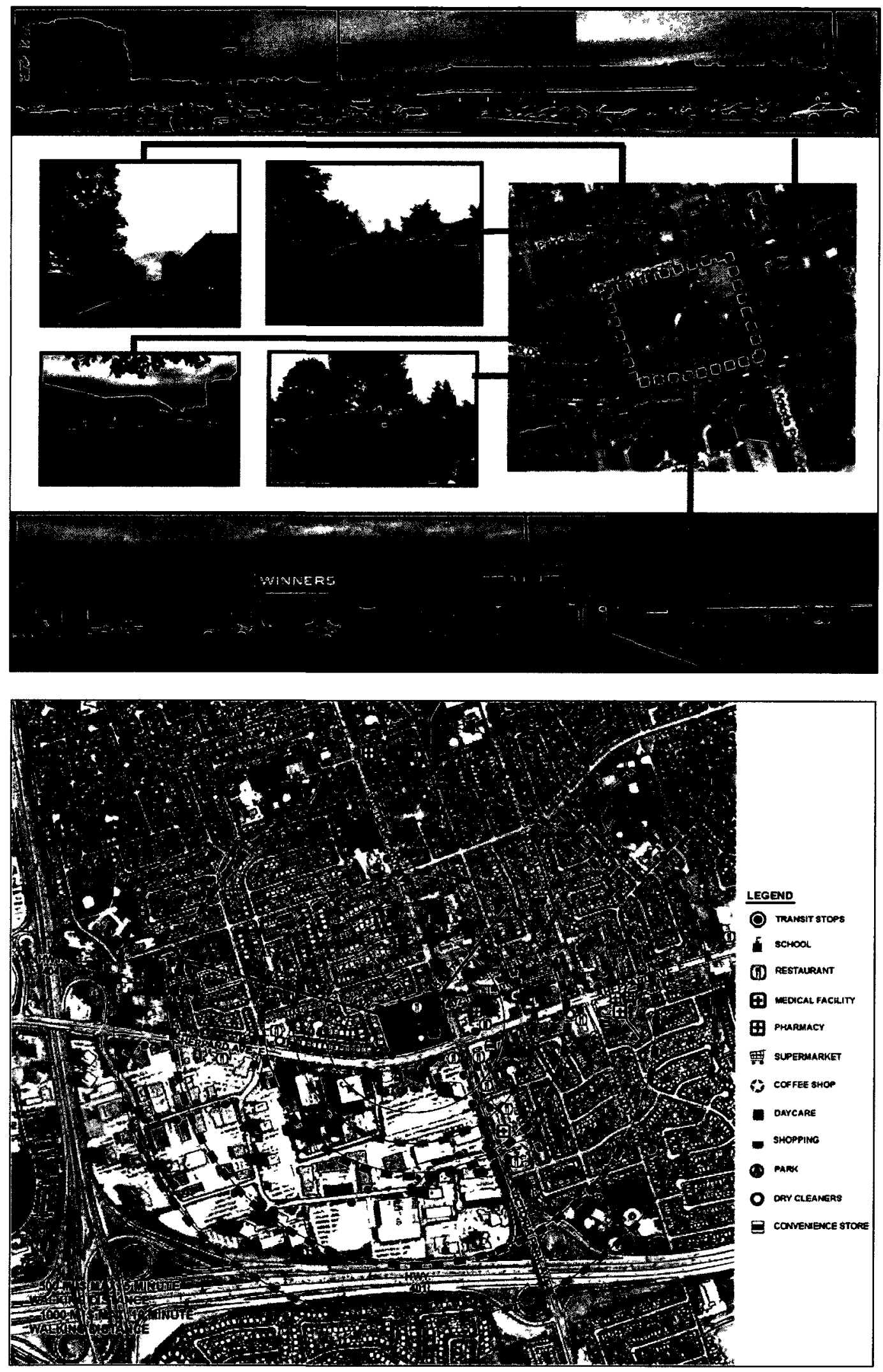


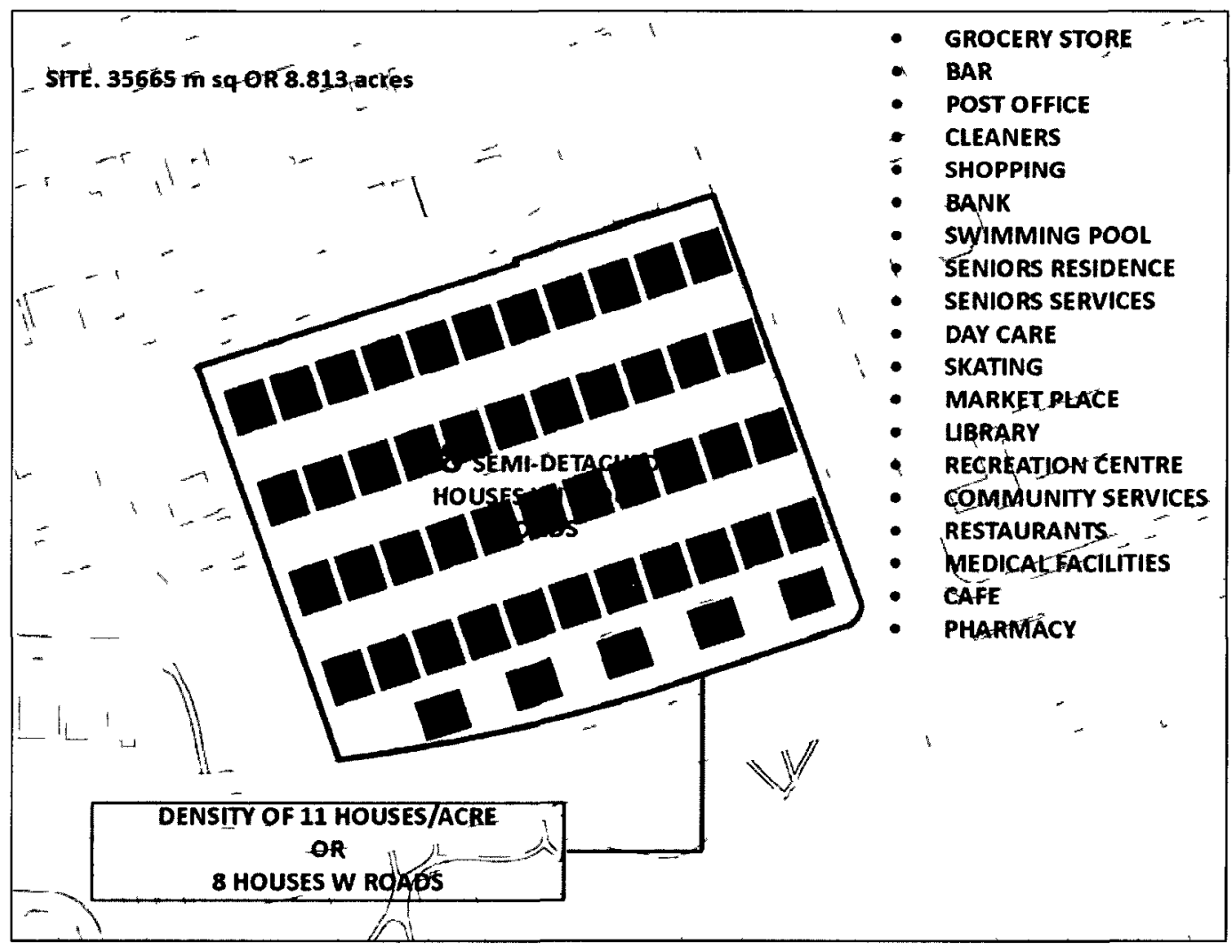

\section{SCHEMATICS}

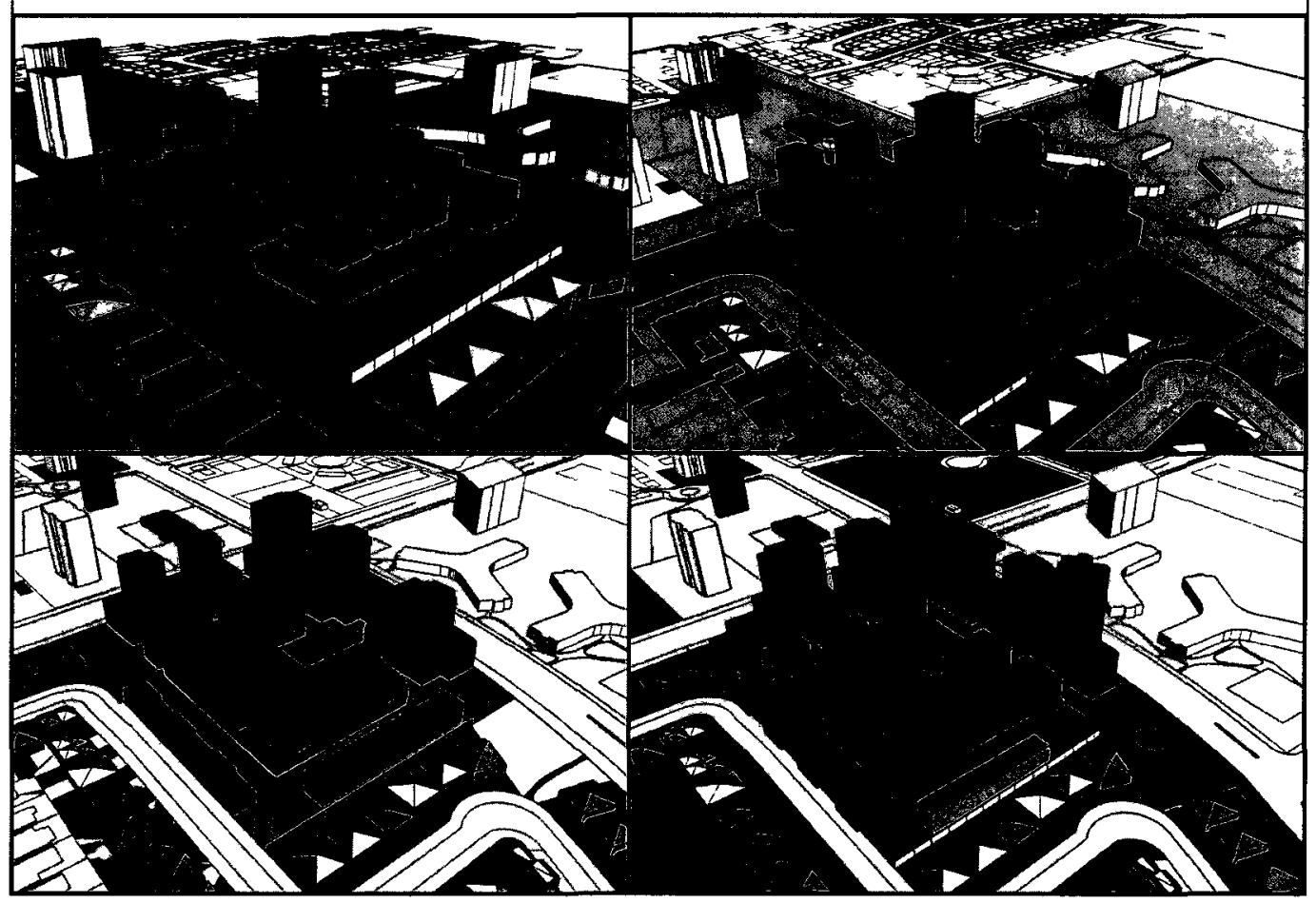



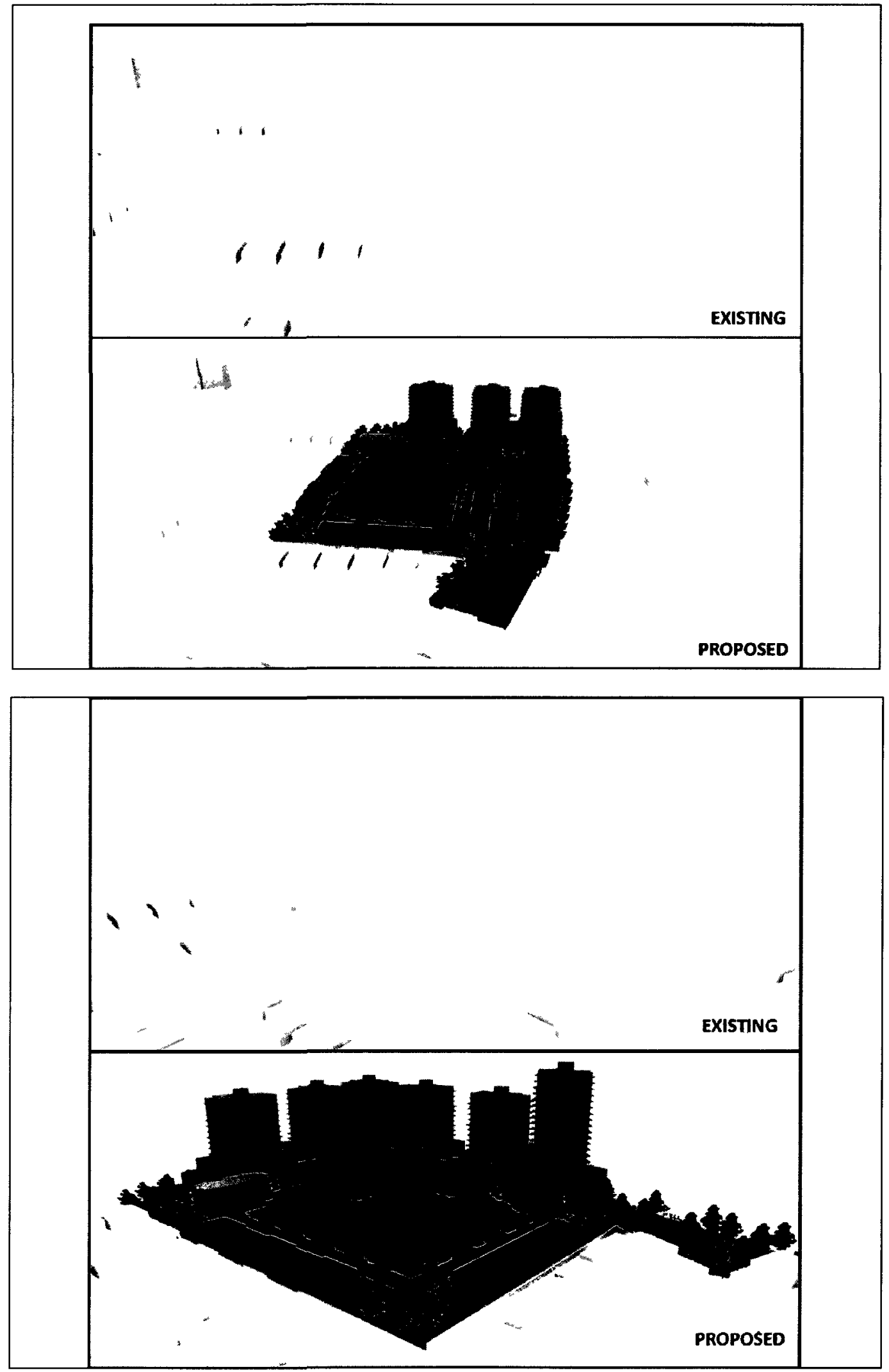

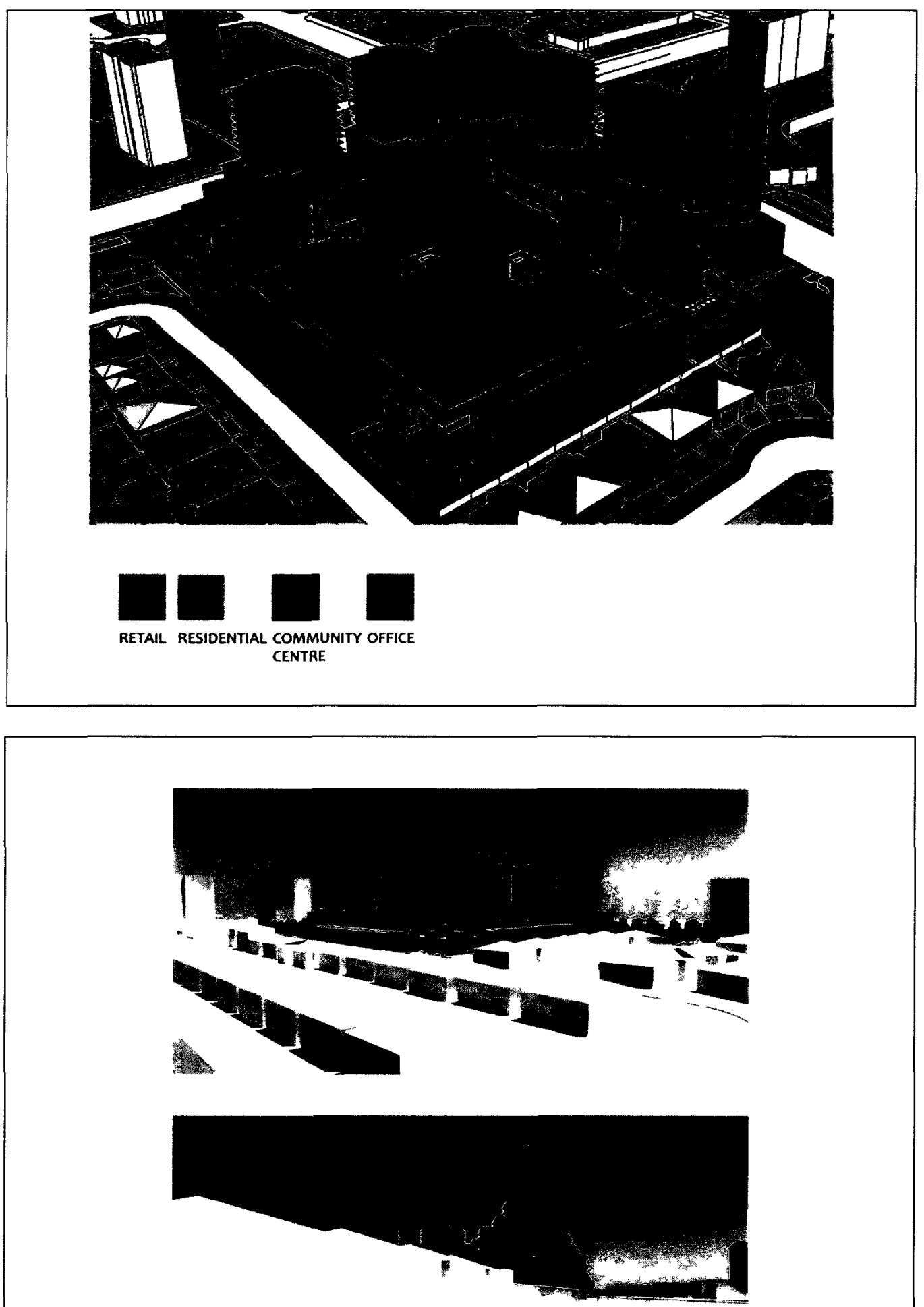


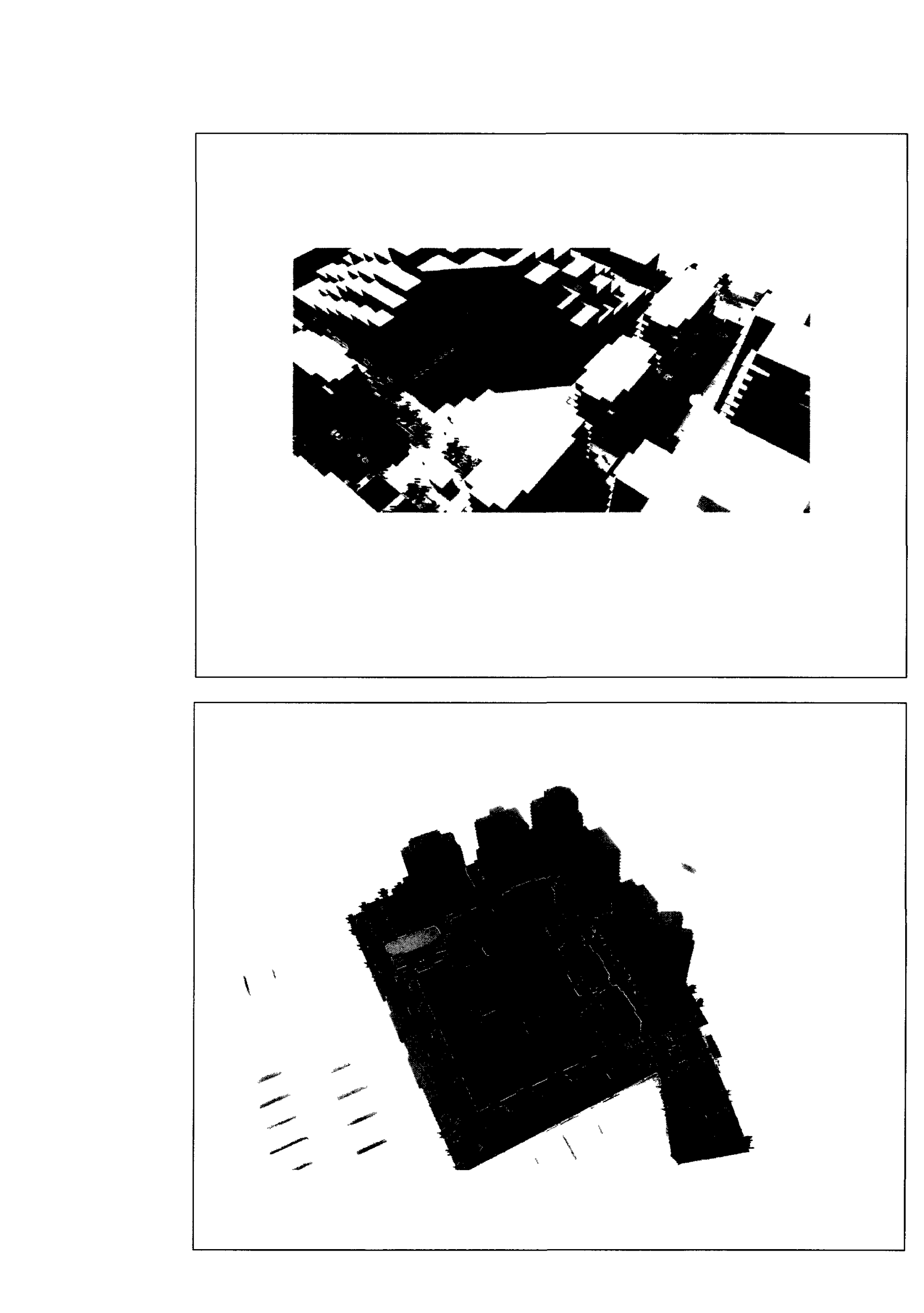



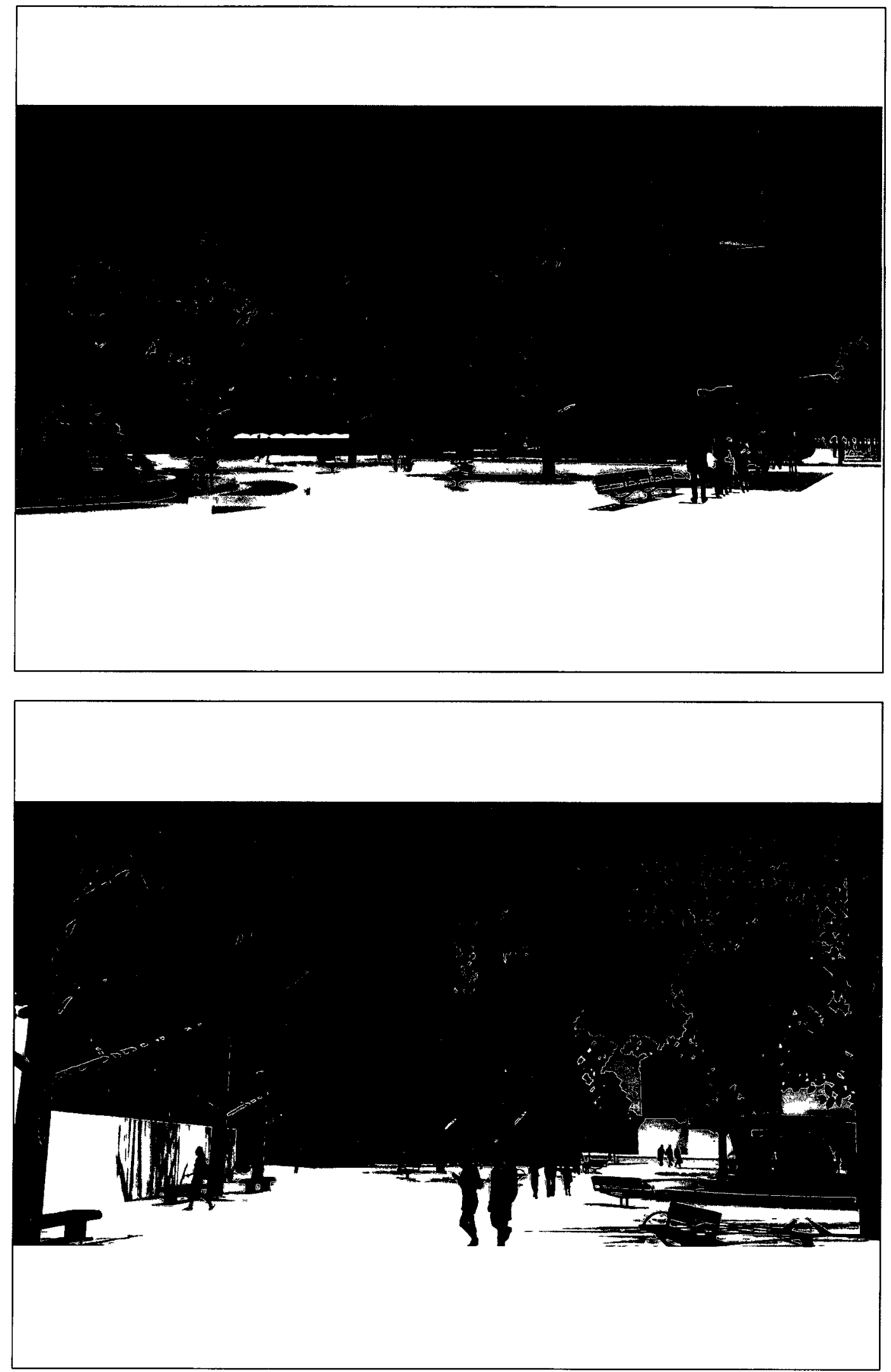

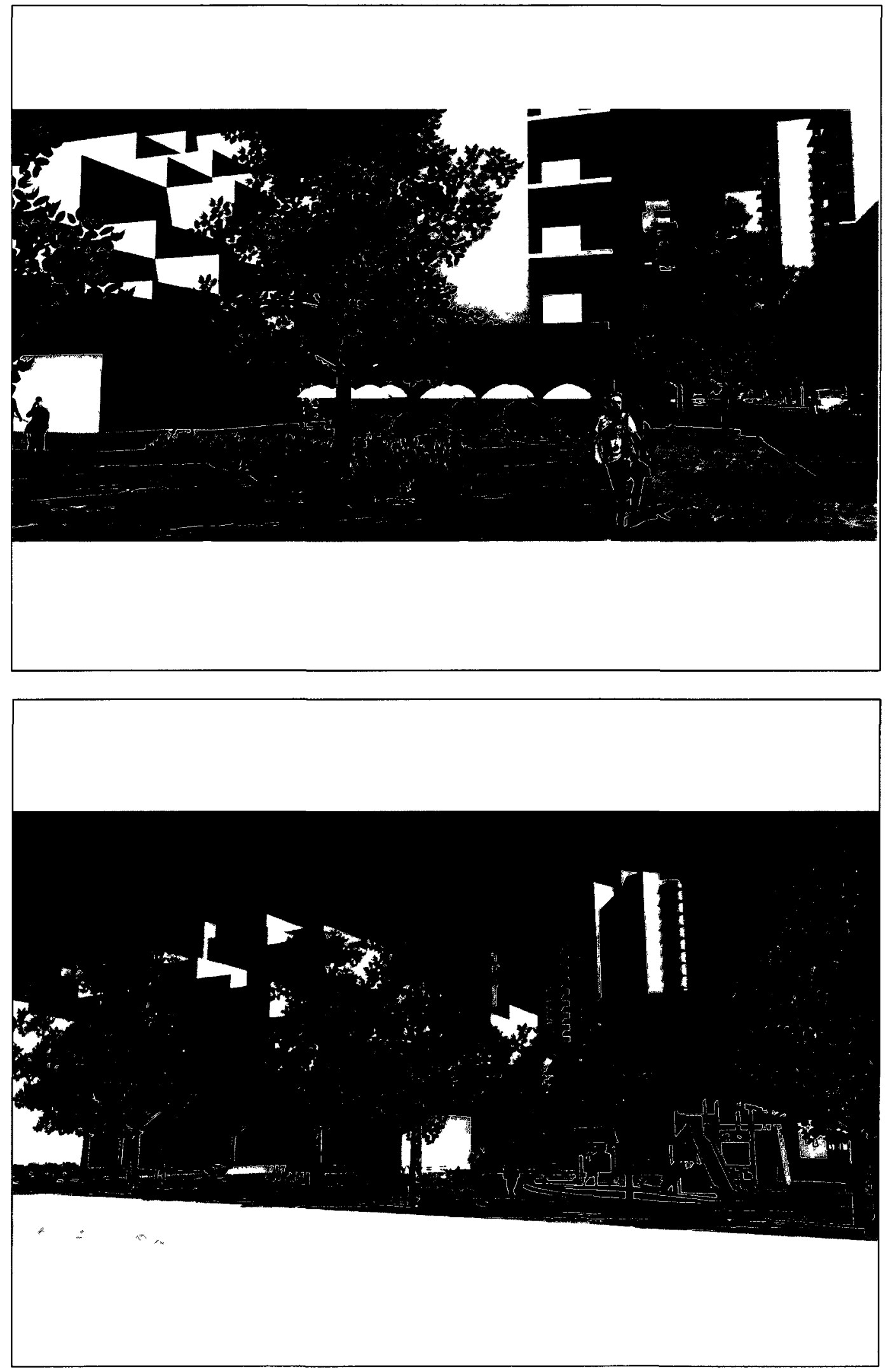

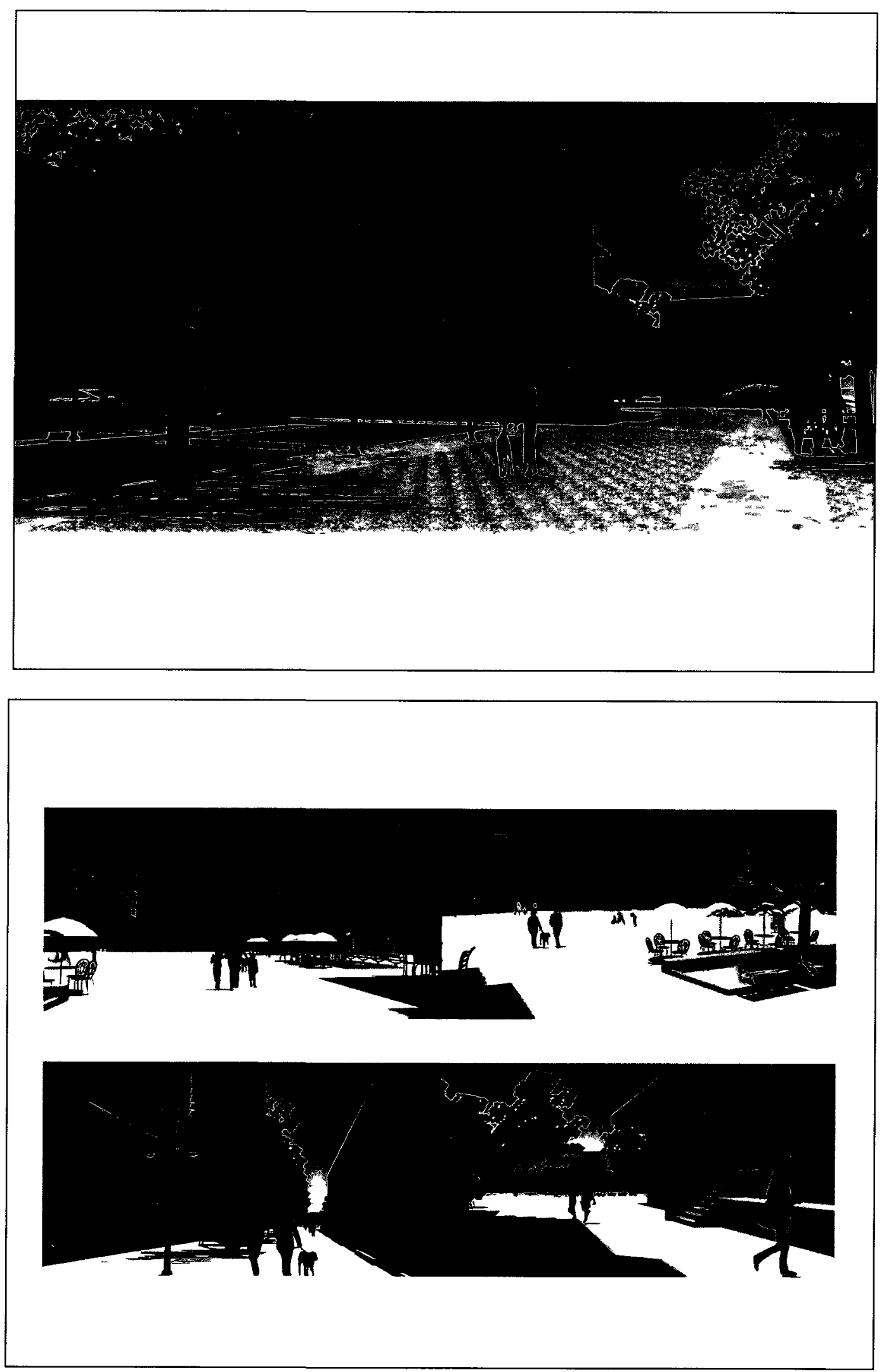


\section{STATISTICS}

AVERAGE NORTH AMERICAN SUBURB: 3-4 UPA

AVERAGE TORONTO SUBURB: 7-10 UPA

Resitdential: 663 Units $=75$ UPA

Office area: $28,090 \mathrm{~m}^{2}$ or $302,370 \mathrm{ft}^{2}$

Cultural or Community area: $18,753 \mathrm{~m}^{2}$ or $201,860 \mathrm{ft}^{2}$

Retail/commercial area: $24,445 \mathrm{~m}^{2}$ or $263,120 \mathrm{ft}^{2}$

Existing Building area: $96,835 \mathrm{ft}^{2}$

Number of Street Parking: $\mathbf{5 0}$ spaces

Number of Parking Spaces Needed:

Residential - 663 parking spaces (underground)

Office/Retail/Community Centre - 678 (underground)

JOBS:

Standards:

Office: 1 job/ $25 \mathrm{~m}^{2}\left(269 \mathrm{ft}^{2}\right)$

Retail: 1 job/ $110 \mathrm{~m}^{2}\left(1184 \mathrm{ft}^{2}\right)$

Proposed Site Job Statistics:

Office: 1123 jobs

Commercial/Retail: 222 jobs

FORMULA

FOR PROTOTYPICAL GREYFIELD REPURPOSING

RETAIL/COMMERCIAL (AMENITIES) + RESIDENTIAL +

COMMUNITY/CULTURAL SERVICES + MEDICAL/OFFICE SPACE +

SEPARATION OF CAR AND PEDESTRIAN PATH + PUBLIC SPACE + STREET

FURNITURE + NATURE + TRANSIT CONNECTION =

FUTURE DEVELOPED SITES

PROTOTYPICAL REPURPOSING FACTORS:

Commercial/Retail: 0.6864

Office: 0.7888

Cultural/Community: 0.5266

TARGET RESIDENTIAL DENISTY:

50-75+ UPA 


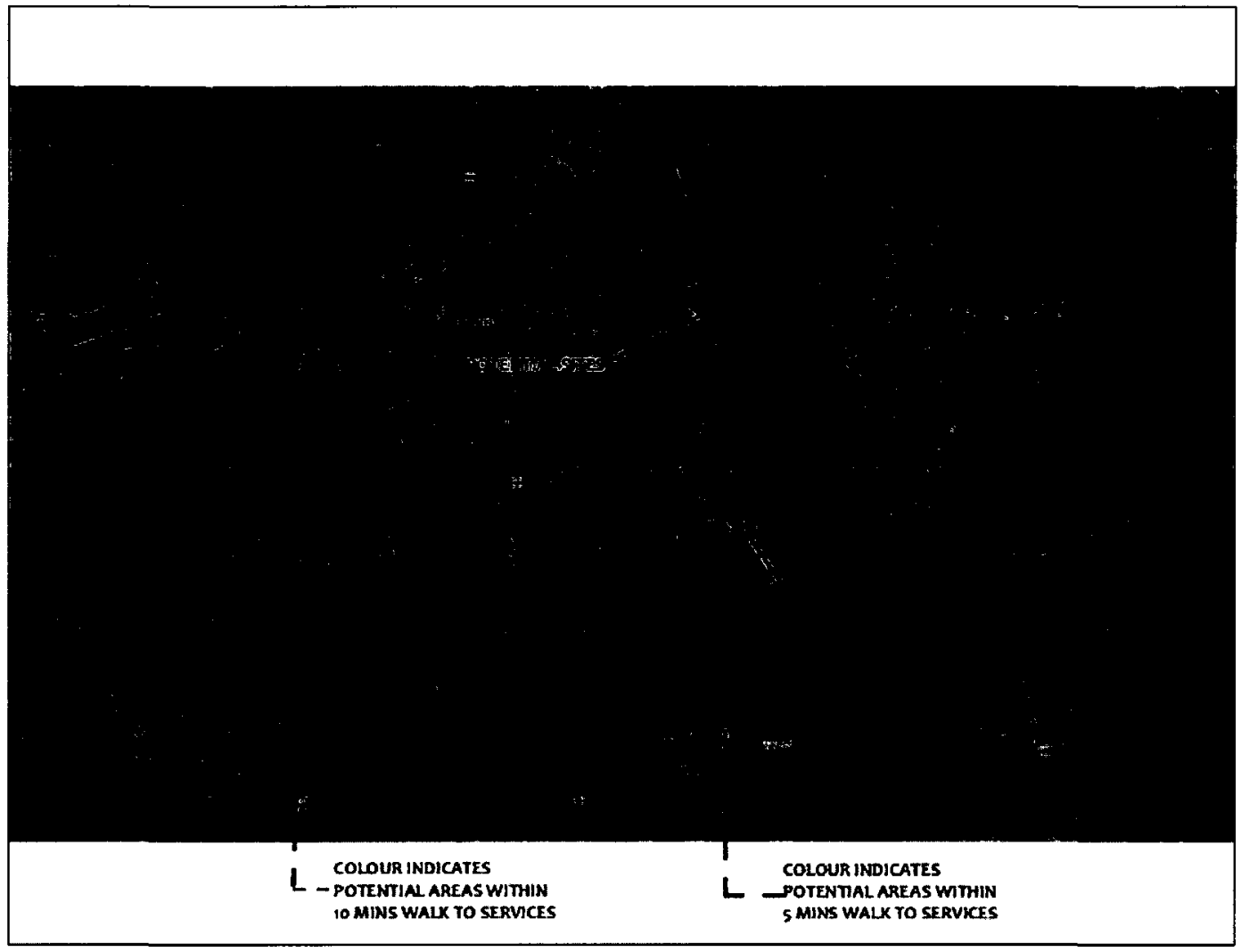




\section{Bibliography}

*Note not all sources listed in the bibliography have been cited

Allsopp, Bruce. Towards a Humane Architecture. London: Frederick Muller, 1974.

Bloom, Nicholas D. Surburban Alchemy. Columbus: Ohio State UP, 2001.

Brain, David. "From Good Neighbourhoods to Sustainable Cities: Social Science and the Social Agenda of New Urbanism." International Regional Science Review 28.2 (April 2005): 217-38.

"CaGBC | LEED Canada rating systems | LEED Canada | neighbourhood developments." CaGBC | Home. Web. 2 Dec. 2009.

<http://www.cagbc.org/leed/systems/neighbourhood_developments/index.php>.

Canada. Statistics Canada. Life in Metropolitan Areas - The City/suburb Contrast: How Can We Measure It? By Martin Turcotte. 11-008.

Carmona, Matthew. Public Places - Urban Spaces. Oxford: Architectural Press, 2003.

Carver, Humphrey. Cities in the Suburbs. [Toronto]: University of Toronto, 1962.

Chermayeff, Serge, and Alexander Tzonis. Shape of Community: Realization of Human Potential. Harmondsworth: Penguin, 1971.

Cozens, Paul Michael. 2008. New Urbanism, Crime and the Suburbs: A Review of the Evidence. Urban Policy and Research. 26(4):429-444.

Curtis, Carey, John L. Renne, and Luca Bertolini. Transit Oriented Development Making It Happen. Burlington, VT: Ashgate, 2009.

Duany, Andres, Elizabeth Plater-Zyberk, and Jeff Speck. Suburban Nation: the Rise of Sprawl and the Decline of the American Dream. New York: North Point, 2000.

Dunham-Jones, Ellen, and June Williamson. Retrofitting Suburbia: Urban Design Solutions for Redesigning Suburbs. Hoboken, NJ: John Wiley \& Sons, 2009.

Eckardt, Wolf Von. Back to the Drawing Board!: Planning Livable Cities. Washington: New Republic, 1978.

Ewing, Reid. "Relationship Between Urban Sprawl and Physical Activity, Obesity, and Morbidity." American Journal of Health Promotion 18.1 (2003).

Farr, Douglas. Sustainable Urbanism Urban Design With Nature. New York: Wiley, 2007.

Fishman, Robert. Bourgeois Utopias: the Rise and Fall of Suburbia. New York: Basic, 1987. 
Fishman, Robert. Urban Utopias in the Twentieth Century: Ebenezer Howard, Frank Lloyd Wright, and Le Corbusier. New York: Basic, 1977.

Frank, Lawrence, Martin Andresen, and Tom Schmidt. "Obesity Relationships with Community Design, Physical Activity, and Time Spent in Cars." American Journal of Preventive Medicine 27.2 (2004).

Frumkin, Howard. "Healthy Places: Exploring the Evidence". Am. J. Public Health, 93, (9), 2003. pp $1451-1456$.

Frumkin, Howard, Lawrence D. Frank, and Richard Jackson. Urban Sprawl and Public Health: Designing, Planning, and Building for Healthy Communities. Washington, DC: Island, 2004.

Garreau, Joel. Edge City: Life on the New Frontier. New York: Doubleday, 1991.

Gaventa, Sarah. New Public Spaces. London: Octupus Publishing Group Ltd., 2006.

Gruen, Victor. The Heart of Our Cities; the Urban Crisis: Diagnosis and Cure. New York: Simon and Schuster, 1964.

Hall, Peter Geoffrey. Cities of Tomorrow: an Intellectual History of Urban Planning and Design in the Twentieth Century. Oxford, UK: Blackwell, 2002.

Hardwick, M. Jeffrey., and Victor Gruen. Mall Maker: Victor Gruen, Architect of an American Dream. Philadelphia: University of Pennsylvania, 2004.

Harris, Richard. Creeping Conformity: How Canada Became Suburban 1900-1960. Toronto: University of Toronto Press, 2004.

Hayden, Dolores. Redesigning the American Dream: the Future of Housing, Work, and Family Life. New York: W.W. Norton, 1984.

Hitchcock, John. Neighbourhood Form and Convenience: a City-Suburban Comparison. Canada: University of Toronto, 1981.

Howard, Ebenezer, and Frederic J. Osborn. Garden Cities of To-morrow. London: Faber and Faber, 1960.

Jacobs, Jane. The Death and Life of Great American Cities. New York: Vintage, 2007.

Katz, Peter. New urbanism toward an architecture of community. New York: McGraw-Hill, 1994.

Keats, John. The Crack in the Picture Window. Boston: Houghton Mifflin, 1957.

Kelly, Barbara M. Expanding the American Dream: Building and Rebuilding Levittown. Albany: State University of New York, 1993. 
Kelbie, Paul. "Rise in Gated Communities Could Pose a Threat to Public Services." The Independent. 27 Sept. 2003. Web. 4 Apr. 2011.

$<$ http://www.independent.co.uk/life-style/house-and-home/property/rise-in-gatedcommunities-could-pose-a-threat-to-public-services-581318.html>.

Krier, Leon. The Architecture of Community. Washington: Island Press, 2009.

Kupfer, Joseph H. Autonomy and Social Interaction. Albany: State University of New York, 1990.

Langdon, Philip. A Better Place to Live: Reshaping the American Suburb. Amherst: University of Massachusetts, 1994.

Larco, Nico. "Suburbia Shifted: Overlooked Trends and Opportunities in Suburban Multifamily Housing." Journal of Architectual and Planning Research 27.1 (2010): 69-87.

"LEED for Neighborhood Development." U.S. Green Building Council. 2009. Web. 2 Dec. 2009. $<$ http://www.usgbc.org/DisplayPage.aspx?CMSPagelD=148>.

Leyden, Kevin. Social capital and the built environment: The importance of walkable neighborhoods. American Journal of Public Health 2003; 93: 1546-51.

Martinson, Tom. American Dreamscape: the Pursuit of Happiness in Postwar Suburbia. New York: Carroll \& Graf, 2000.

McClelland, Michael, and Graeme Stewart. Concrete Toronto: a Guidebook to Concrete Architecture from the Fifties to the Seventies. Toronto: Coach House, 2007.

Mikellides, Byron. Architecture for People. London: Studio Vista, 1980.

Moore, Adrian, and Rick Henderson. "Plan Obsolescence -." Reason Magazine. June 1998. Web. 2 Dec. 2009. <http://reason.com/archives/1998/06/01/plan-obsolescence>.

Mozas, Javier. Densidad; Density : Nueva Vivienda Colectiva : New Collective Housing. VitoriaGasteiz: a+t Ediciones, 2006.

Mumford, Eric Paul. The CIAM Discourse on Urbanism: 1928 - 1960. Cambridge, Mass. [u.a.: MIT, 2000.

Mumford, Lewis. The City in History. London: Penguin, 1961.

Nelson, Arthur C. "America Circa 2030: The Boom to Come." Architect October (2006).

Newman, Oscar. Defensible Space Crime Prevention through Urban Design. New York, NY: Macmillan, 1972.

New Urbanism. Web. Oct. 2009. <http://www.newurbanism.org/>.

Oldenburg, Ray. The Great Good Place: Cafés, Coffee Shops, Community Centers, Beauty Parlors, General Stores, Bars, Hangouts, and How They Get You through the Day. New York: Paragon House, 1989. 
Osborn, Frederic J., Arnold Whittick. New Towns: Their Origins, Achievements and Progress. London: Leonard Hill, 1977.

Popenoe, David. The Suburban Environment: Sweden and the United States. Chicago: University of Chicago, 1977.

Porteous, Douglas J. Environment \& Behavior: planning and everyday urban life. Philippines: Addison-Wesley Publishing Company, 1977.

Putnam, Robert D. Bowling Alone: the Collapse and Revival of American Community. New York: Simon \& Schuster, 2000.

Rogers, Richard George, and Philip Gumuchdjian. Cities for a Small Planet. London: Faber and Faber, 1997.

Roseland, Mark. Toward Sustainable Communities. British Columbia: New Society Publishers, 2005.

Rouse, James W. Cities That Work for Man, Victory Ahead. San Juan, Puerto Rico: S.n., 1967.

Ruskin, John. Sesame and Lilies. New York: Chelsea House, 1983.

Saunders, William S. Sprawl and Suburbia. Minneapolis, MN: University of Minnesota, 2005.

Sennett, Richard. "The Brutality of Modern Families." Marriages and Families. Ed. Helena Z. Lopata. New York: D. Van Nostrand, 1973.

Sewell, John. The Shape of the City: Toronto Struggles with Modern Planning. Toronto: University of Toronto, 1993.

Sewell, John. The Shape of the Suburbs: Understanding Toronto's Sprawl. Toronto: University of Toronto, 2009.

Sexton, Richard. Parallel Utopias: the Quest for Community : the Sea Ranch, California, Seaside, Florida. San Francisco: Chronicle, 1995.

SmartCode Version 9.2. Town Paper, 2009.

Smart Growth Online. Web. Nov. 2009. <http://www.smartgrowth.org/>.

Smith, Peter F. Architecture and the Human Dimension. London: George Godwin Limited, 1979.

Sobel, Lee S., Ellen Greenberg, and Steven Bodzin. Greyfields into Goldfields: Dead Malls Become Living Neighborhoods. [San Francisco, Calif.]: Congress for the New Urbanism, 2002.

Solomon, Lawrence. Toronto Sprawls: a History. Toronto: University of Toronto, 2007. 
Steuteville, Robert. "Market Trends Favor NU." New Urban Network. 1 Apr. 2007. Web. 04 Apr. 2011. <http://newurbannetwork.com/article/market-trends-favor-nu>

Talen, Emily. Design for Diversity: Exploring Socially Mixed Neighborhoods. Amsterdam: Architectural, 2008.

Talen Emily, New Urbanism and American Planning: The Conflict of Cultures. New York: Routledge, 2005.

Tamay, Stella. "Green neighborhoods: the neighborhood is a building block for sustainable development." Urban Land 64.5 (2005): 63-68.

Tennenbaum, Robert. Creating a New City: Columbia, Maryland. Columbia, MD: Published by Partners in Community Building and Perry Pub., 1996.

Von Eckardt, Wolf. Back to the Drawing Board! Planning Livable Cities. Washington: New Republic Books, 1978.

Wall, Alex. Victor Gruen: from Urban Shop to New City. Barcelona: Actar, 2005.

Wernick, Jane. Building Happiness: Architecture to Make You Smile. London: Black Dog, 2008.

Wilcox, Alana, Christina Palassio, and Jonny Dovercourt. GreenTOpia: towards a Sustainable Toronto. Toronto: Coach House, 2007.

White, Richard. Urban Infrastructure and Urban Growth in the Toronto Region, 1950's to the 1990's. Toronto: Neptis Foundation, 2003.

Wright, Gwendolyn. Building the Dream: a Social History of Housing in America. New York: Pantheon, 1981. 